Universidade de São Paulo

Faculdade de Filosofia, Letras e Ciências Humanas

Departamento de Geografia

\title{
OBJETOS, ATOS E SITUAÇÓES NO \\ MORAR NA PERIFERIA DA METROPOLE Momentos e Implicação
}

Alexandre Souza da Rocha

Tese de doutorado
apresentada à Faculdade de
Filosofia, Letras e Ciências
Humanas da Universidade de
São Paulo. Sob orientação da
Profa. Dra. Amélia Luisa
Damiani.

São Paulo, 2007 
À

Tuca 


\section{Índice}

$\begin{array}{ll}\text { A complexidade é crescente } & 10\end{array}$

O território de Jandira $\quad 50$

Situações críticas a nós mesmos

O processo político de produção da pobreza o caso da moradia

Ambientes de autoconstrução, a conveniência do 148 real?

Os limites da urbanização

Os "bicos"

Necessidade, desejo e fruição

O ambiente escolar como processo e projeto de 189 aprendizagem 


\section{Resumo}

Este trabalho é uma tentativa de compreensão crítica dos processos sociais de produção e reprodução das periferias. 0 tornar espaços periféricos. Neste sentido buscou-se, a partir da implicação do pesquisador, compreender os ambientes de autoconstrução. Baseados na compreensão dialética que a vida vivida é sempre enfrentamento prático das contradições, estabelecemos relações que permitem apresentar um nível de entendimento sobre o viver nos ambientes de autoconstrução. $\mathrm{Na}$ intensidade da vida vivida, a preponderância das necessidades é mais um dos enfrentamentos, desafios são encarados como ritmo do dia-a-dia. O mobilizador não é a dificuldade. O universo do desejo propicia a ampliação da interpretação, não é explícito, está no âmbito da subjetividade, e imerso nas inúmeras alienações. Seria inexplicável a intensidade da vida nestes ambientes sem o desejo como mobilizador. Não são somente pessoas inertes, movimentadas pelo econômico da necessidade. 


\section{Resume}

This work proposes to try a critical understanding about the outskirts in a social process of his production and re-production. To become peripheral spaces. In this way we seek, as from the researcher's implication, to understand the self-constrution's ambience. Based in a dialectical view that the living life is always a practical confrontation of contradictions, we set relations which allows introduce a certain level of comprehension about the living life in the self-constrution's ambience.

At intensity of living life, the preponderance of necessities is more one confrontation, defiances are faced as rhythm of the everyday. What mobilizes is not the dificult. The universe of desire supports increase the interpretation, it is not explicit, but in subjectivity's ambit, and immersed in so many alienations. Would be inexplicable the life's intensity on these selfconstrution's ambience without the disere as force wich mobilizes. They are not only inert people, but set in motion by the economic of desire. 


\section{Justificativa}

Existe uma discussão necessária sobre a periferia como alternativa ao déficit habitacional. A autoconstrução é uma válvula de escape do processo acelerado de mobilização da população brasileira para os grandes centro urbanos.

Através da análise do pesquisador como implicado com seu objeto desenvolveu-se algumas explicações sobre momentos e situações da periferia como construção resultante das contradições sociais do modo de produção capitalista.

Uma parte do que aqui apresento é um resumo situando o município de Jandira, para que conheçam a realidade na qual estou implicado, pois é o relacionamento intenso com as questões que envolvem o espaço onde vivo que me permitem uma série de interpretações.

Outro capítulo refere-se a uma tentativa de explicação para a teimosia em continuar nas disputas de projetos no governo de Jandira. É uma avaliação de conjuntura e nesta, aparentemente, a possibilidade de contribuição é a melhor alternativa na busca da transformação da sociedade. Por melhor e por mais 
importantes que sejam as intenções nas disputas dos projetos, sozinho, não conseguiremos contribuir em nada. "Na qualidade de agente de transformação, e mesmo que se leve em conta o papel desempenhado por personalidades determinantes, é sempre como coletivo que o particular se manifesta." ${ }^{1}$ Portanto, buscamos juntar projetos ou grupos na construção de possibilidades de mudanças, e neste trecho da tese pretende-se ajudar a entender algumas disputas.

O capítulo sobre o processo político de produção da pobreza parte da constatação que não se combate a pobreza, mas visa-se os pobres como objeto de inúmeras estratégias. A favela é uma das formas mais visíveis das desigualdades do processo de produção da pobreza e, portanto, é extremamente atraente para aqueles que procuram por necessitados (inclusive economicamente) $)^{2}$. Ou melhor, nada melhor para o exercício do poder que aqueles que são seu resultado. Na maioria das vezes, os moradores de lugares em situação de risco estão disponíveis para a ação do poder, e são inúmeros os discursos atraentes,

\footnotetext{
${ }^{1}$ ALTOÉ, Sônia, (organizagora). René Lourau: Analista Institucional em Tempo Integral. São Paulo: Hucitec, 2004. p.59

${ }^{2}$ SILVA, Flávia E. Favela, que negócio é este? Um estudo sobre o projeto de urbanização da favela do Jaguaré no contexto dos negócios urbanos e de sua reprodução crítica. Dissertação de mestrado Programa de Pós-graduação em Geografia Humana, Departamento de Geografia, FFLCH, USP, São Paulo: 2006
} 
pois apelam para a situação que aflige a todos que ali residem. A imposição de lógicas muito potentes já está patente na condição de moradia, o próprio espaço é revelador, principalmente nas grandes metrópoles, que são resultados de acúmulos enormes da sociedade burocrática de consumo dirigido.

Temos uma parte com o título "ambientes de autoconstrução, a conveniência do real?" apresentando como uma tese possível sobre o espaço da periferia urbana é, talvez, se pensarmos ao nível da tríade concebido - percebido - vivido, os ambientes de autoconstrução podem também ser interpretados como uma demonstração da limitação do Estado no sentido da organização total da sociedade.

Na seqüência temos a discussão da produção de áreas de risco com o capítulo sobre os limites da urbanização, no qual verificamos vários elementos críticos, reveladores do processo de produção e reprodução das relações sociais de produção. ${ }^{3}$

Existe ainda uma pequena observação sobre o chamado trabalho informal no item "os bicos" e uma tríade analítica dos ambientes de autoconstrução: necessidade, vontade e fruição.

\footnotetext{
${ }^{3}$ LEFEBVRE, H. A Re-produção das Relações de Produção. Publicações Escorpião. Porto, 1973.
} 
Esta é uma tríade explicativa de várias situações destes ambientes. 


\section{A complexidade é crescente}

Como explicar o envolvimento de um pesquisador com seu objeto de pesquisa sem parecer uma auto-exaltação? É necessário que um método - ou a teoria - permeie integralmente o que se escreve.

Inicialmente devemos deixar claro que esta pesquisa também é resultado de enfrentamentos aos ditames dos processos de produção e reprodução das relações sociais de produção. A idéia é ainda mais arrogante, é um enfrentamento como agente que procura contribuir para a transformação da realidade existente. Neste enfrentamento vários caminhos foram sendo percorridos e, cada vez mais, os imbricamentos de uma teia de situações, criada pelas atividades desenvolvidas em ensino, movimentos sociais, partido político, pesquisa, governo e projetos em disputa, levavam-nos a assumir compromissos.

No emaranhado da teia de situações de nosso envolvimento é recorrente chegar a conclusões ou constatações bastante interessantes, porém não se configuram como uma tese. O envol- 
vimento passa por reflexões teóricas já constituídas ou em vias de elaboração, individual e coletivamente, sempre cumulativa, e ao mesmo tempo vão sendo superadas pelas que surgem a partir delas e muitas vezes negando o que acabamos de adquirir. Somente a título de exemplo, agora relativamente aos pressupostos de uma ação política, tem-se: No processo de elaboração do relatório técnico para o "Plano Diretor Participativo de Jandira" (mais a frente entraremos nos detalhes) foi confeccionado um mapa com as áreas de habitação precária do município; porém, dois meses depois, na apresentação para as comunidades do resultado da leitura técnica a favela, junto à estação de trem do Sagrado Coração (a maior favela do município), não estava mais lá. Parte ocupou uma construção em ruínas no norte do município e outros pegaram a indenização da CPTM e foram morar de aluguel ou em casa de parentes. Os técnicos da consultoria ficaram indignados por apresentar um mapa desatualizado. Mas a realidade é muito mais dinâmica que as representações técnicas que fazem dela. Ora se o espaço metropolitano é dinâmico, principalmente por suas qualidades urbanas, não há como escapar das celeridades dos processos. 
Uma primeira situação que, necessariamente, deve ser esclarecida está ao nível da concepção do mundo, entendo esta, a partir de Henri Lefebvre, como "uma visão de conjunto da natureza e do homem, uma doutrina completa. Num sentido, uma concepção do mundo constitui o que chamamos tradicionalmente de uma filosofia. Contudo, a expressão possui significado mais amplo do que o termo filosofia. Em primeiro lugar, toda concepção do mundo implica uma ação, isto é, algo mais do que uma 'atitude filosófica'. Mesmo que tal oração não esteja formulada e explicitamente unida à doutrina, mesmo que seus vínculos permaneçam indefinidos e a ação implícita não produza um programa, nem por isso sua existência é menos real... Em segundo lugar, uma concepção do mundo não é, forçosamente, obra deste ou daquele 'pensador'. Trata-se, antes, do produto e da expressão de uma época. Para atingir e formular uma concepção do mundo, devemos estudar as obras dos que a enunciaram, mas pondo de lado os matizes e os pormenores; precisamos nos esforçar por abarcar o conjunto."

\footnotetext{
${ }^{4}$ LEFEBVRE, Henri. O Marxismo. Coleção "Saber Atual. São Paulo: Difel. 1974. pp.10-11
} 
A concepção do mundo em que me incluo é o marxismo, não meramente mais um "ismo", que no nosso tempo sugere inúmeras banalizações. Posso mais uma vez utilizar-me de Lefebvre que certa vez se auto definiu um "marxista romântico". Mas com todas as implicações que esta concepção de mundo possui: "O marxismo recusa estabelecer uma hierarquia exterior aos indivíduos (metafísica); por outro lado, porém, não se encerra, como o individualismo, na consciência do indivíduo e no exame desta consciência isolada. O marxismo toma conhecimento de realidades que escapam ao exame de consciência individualista: São realidades naturais (a natureza, o mundo exterior), práticas (o trabalho, a ação), sociais e históricas (a estrutura econômica da sociedade, as classes sociais, etc.). Além disso, o marxismo rejeita, deliberadamente, a acabada, imóvel e mútua subordinação dos elementos do homem e da sociedade; tãopouco admite a hipótese de uma harmonia espontânea. Na realidade, verifica contradições no homem e na sociedade. ${ }^{55}$ Aliás, boa parte do mundo acadêmico, atualmente, esforça-se por desconsiderar o legado de Marx, e, muitas vezes, percebemos as insistentes formas de relegar aos marxistas os aspectos de um

${ }^{5}$ LEFEBVRE, Henri. O Marxismo. Coleção “Saber Atual. São Paulo: Difel. 1974. p.13 
passado extinto, como o jurássico, ou em termos de ironias "os dinossauros". Como não estamos num desfile de modas, não há problema ser "démodé" - o próprio termo já está fora de moda, o que o torna ainda mais apropriado.

Existem questões delicadas e várias dificuldades em tornar experiências - de geógrafo, professor, militante e de morador da periferia - parte de uma tese, pois sempre terminam por ser constatações, prenhes de críticas aos processos de produção e reprodução das relações sociais de produção, porém trata-se de uma visão parcial (ou particular) da realidade. Ao mesmo tempo é constante a sensação de que seria interessante como contribuição ao mundo acadêmico um relato dessas experiências, não por uma visão empirista da pesquisa, pelo contrário, é através da importância da compreensão dialética da sociedade que essas experiências tornam-se significativas, pois estão na complexidade da realidade vivida na periferia da metrópole.

Nesta discussão a noção de implicação é muito apropriada, pois permite ao nível do método abarcar a dimensão política da vida. Pretende-se entrar com toda intensidade possível na complexidade sempre crescente dos objetos, atos e situações, que vem sendo enfrentada, não só neste período de aluno do 
programa de doutorado do Departamento de Geografia, da Faculdade de Filosofia Letras e Ciências Humanas da Universidade de São Paulo, mas através das oportunidades que tivemos nos cursos regulares da USP, na Associação dos Geógrafos Brasileiros - AGB -, no Laboratório de Geografia Urbana da USP - Labur

-, na E.E. Josepha Pinto Chiavelli e outras escolas estaduais, no Partido dos Trabalhadores - PT -, na prefeitura de Jandira e em alguns movimentos sociais. Neste ponto, sobre a implicação, Ricardo Baitz é fundamental, através de seu artigo "A implicação: um novo sedimento a se explorar na Geografia?" escrito para o Boletim Paulista de Geografia da AGB - São Paulo. Assim como o livro René Lourau: Analista Institucional em tempo integral de Sônia Altoé; e os excertos sobre "Les IrrAlductibles - Revue Interculturelle et planétaire d'analyse institutionnelle. Des dispositifs I, no 6, outubro de 2004", traduzidos por Amélia Luisa Damiani. Alguns outros textos sobre análise institucional e implicação disponíveis na internet e o livro "As Pedagogias Institucionais" de Jacques Ardoino e René Lourau da editora RiMa. 
Noções como análises institucionais, implicação, pertencimento, deverão ser esclarecidas. ${ }^{6}$ Através das experiências obtidas nos embates nas atividades profissionais na Prefeitura de Jandira ou na Escola Estadual Josepha Pinto Chiavelli, nos enfrentamentos da atuação política no PT ou em alguns movimentos sociais é possível chegar a algumas explicações sobre a periferia metropolitana.

O nível da experiência profissional não pode ser confundido com a pesquisa? Seria conveniência e oportunismo utilizar-me da experiência de atuar em áreas técnicas para construir um pensamento crítico sobre os limites e possibilidades de utilizar o conhecimento crítico dos processos de produção do espaço no universo do embate que é a administração pública neste país? Aliás, com todas as resistências possíveis de ser apresentadas para a participação em qualquer governo, principalmente pela crítica necessária do conluio Estado e Capital na dominação do Social, os compromissos assumidos através da participação em

\footnotetext{
${ }^{6}$ É importante deixar claro que os grupos de discussão existentes no Labur, especialmente os organizados pela professora Amélia Damiani, estudam estes e outros momentos do conhecimento, existe um nível de compreensão construído nos grupos de estudo, que individualmente o pesquisador não chega. Temos aqui uma compreensão necessária: a forma de organização do Labur leva a uma profundidade nos estudos que o indivíduo na sua arrogante sapiência pode até chegar sozinho, mas não com a mesma intensidade, e muito menos com a reciprocidade dos envolvimentos, sem contar com a possibilidade do lúdico que o ato de encontrar-se proporciona.
} 
várias situações sinalizaram para a importância do enfrentamento político necessário que a crítica coloca também dentro de um governo. Não é necessário ocupar cargos de poder para enfrentar estas determinações, pelo contrário, é ao nível do social e do fortalecimento de movimentos contrários às lógicas potentes, que construiremos outras possibilidades, descobrindo e reforçando negações a este domínio do Estado e do Capital sobre o Social.

Na realidade é uma compreensão crítica do poder que precisamos por em foco; deveríamos chegar ao poder para acabar com o poder, diluí-lo em conexões e ambientes democráticos, buscando diminuir os inúmeros níveis de representações a que estamos submetidos. Existe uma afirmação do Frei Beto que, além de pertinente, pode ser a base para uma compreensão de classe sobre os absurdos da atual conjuntura política: "o poder é mais sedutor que o sexo e o dinheiro, pois facilita o acesso aos dois". Portanto, precisamos de um movimento político que enfrente a idéia de poder, que responsabilize a sociedade sobre o poder, diminuindo assim um dos sustentáculos do poder, o fascínio de ser ou ter poder. Nem o movimento sindical, nem os partidos de esquerda ou extrema esquerda, nem ONGs ou terceiro 
setor, nem os mais variados movimentos sociais estão preparados para ser alternativa de poder. Em alguns sentidos podem ser alternativas de enfrentamento ao poder, mas desconheço "substâncias" que possam dirimir as estruturas lógicas existentes.

Eleições não são os imperativos de nossa história, podem definir um momento da luta, e não basta ganhar governos, temos de produzir liberdades como alternativas de poder. Mas as dificuldades de "por dentro" construir projetos alternativos é muito grande, para não dizer impossível.

Nesse "por dentro" é possível aferir níveis de possibilidades de atuação, a maioria delas é procurar construir formas de diluir os níveis de representação da relação entre Estado e Sociedade, aí duas estratégias podem ser apontadas: os conselhos populares e a ampliação de sua capacidade de ação na gestão local dos municípios.

Em Jandira, montamos conselhos paritários (50\% representantes do poder público e $50 \%$ representantes da sociedade civil organizada) em setoriais de educação, saúde, meio ambiente, segurança, orçamento participativo, habitação, criança e adolescente, entre outros. Bem como nas escolas, nos postos de 
saúde, no hospital. A eficácia na diluição do poder, na democratização e na transparência é questionável. A possibilidade de ampliar o nível de consciência e de participação da população é um fato, mas, ao nível prático, muito pouco acontece. A maior parte das decisões sobre investimentos e/ou prioridades não passa pelos conselheiros, muito menos atitudes de construção coletiva de projetos. Os projetos chegam prontos para ser discutidos e aprovados, raramente são emendados e nunca são reprovados. Aliás, existe um nível de conivência entre a representação da sociedade civil e as propostas do governo. Podemos justificar, em parte, que parcelas das lideranças dos movimentos fazem parte do governo. Em parte podemos falar de cooptação. Ou do império da racionalidade tida como técnica.

Trata-se da conveniência de ser um governo de esquerda. Não tem esquerda contra e a direita, pelo menos em Jandira, não sabe lidar com mobilização popular.

Outra situação é a da limitação da formação das lideranças, muitas vezes não estão preparadas para a formulação de projetos, qualquer que seja o projeto, alternativo ou na mesma linha. Uma constatação possível é que qualquer liderança contestatória ganha cargo, independente da competência. 
"...se a integração segundo valores comunitários é efetivamente um dos elementos que compõem a sociedade, não deve ser confundida - sob pena de tomar a ideologia pelo objeto 'sociedade' que ela mascara - com a própria estrutura social. ...não podemos participar de todos os valores que cimentam a comunidade ou, pelo menos, não o podemos fazer com a mesma intensidade de todos os outros membros, já que nunca pertencemos a todas as formas singulares e segmentarias de organização social nem a todas as formas segmentarias universais constituídas a partir das categorias universais da idade e do sexo. ...Embora o inventário de nossos pertencimentos socialmente constituídos seja finito, o inventário de nossas referências é muito mais aberto. ...Como 'usuário' (um termo aproximado) das instituições existentes, eu me ajusto, pelo menos publicamente, ao sistema de referência das normas que elas simbolizam e encarnam, da proibição do incesto à interdição de passar cheque sem fundos. ...Como 'mantenedores' (novamente um termo 
aproximado) das instituições, os particulares podem ser classificados, muito esquematicamente, em dois conjuntos:

a) Em primeiro lugar, todos os usuários cooperantes que não põem perigosamente em questão as instituições.

b) Em segundo lugar, os mantenedores podem ser percebidos como constituindo uma ou mais categorias privilegiadas, a título variado, em relação à massa de particulares... o simples fato de aceder a um grau na hierarquia (formal ou informal) permite perceber o começo de um processo de integração, mesmo se a participação nos objetivos e nos valores da organização que nos hierarquiza estiver longe de ser incondicional... Quantos indivíduos ventríloquos não falam senão porque as instituições falam por intermédio deles, porque a têm, literalmente, 'sob a pele'! Porém, do mesmo modo, quantos se recusam a aderir às instituições, a despeito de sua vida cotidiana 
ser totalmente composta de um tecido institucional que implica um certo grau de consentimento, de adesão, de engajamento e de participação (senão de integração) "17

Acrescentemos uma discussão difícil mas, em algum momento, deverá ser abordada: os desvios... vários, de caráter, de função, de dinheiro, de projeto, de compromissos... Muitas das nossas lideranças estão comprometidas com outras situações diferentes dos enfrentamentos que as despontaram, e deram-Ihes o status de nossas lideranças; com certeza não foram suas rendas. Porém, em muitos casos, o ato de nos representar rendeIhes uma verba maior, pelo acesso a cargos ocupados, daí a "eternidade" dos nossos representantes, independente do nível de radicalidade. São muitos os âmbitos de representação, a que estamos sujeitos, mantendo sempre os mesmos nomes como candidatos.

Em parte percebe-se uma falta de interesse em participar no processo de sucessão nas representações e, por vezes, a montagem de diretorias, conselhos e outras formas de representação é resultado de processos de convencimento sobre a impor7 ALTOÉ, Sônia, (organizagora). René Lourau: Analista Institucional em Tempo Integral. São Paulo: Hucitec, 2004. p.53 
tância da constituição de um grupo que assuma a direção/representação por um período, e menos disputa por cargos.

Instâncias de representação de maior projeção são mais disputadas, tem-se uma variedade de projetos participando do jogo político. As diferenças de concepção são apresentadas e a disputa dá-se na contraposição dos projetos.

Mas em muitos casos, e estes são os de maior preocupação, não é a importância da constituição de um grupo para assumir responsabilidades, ou sequer a disputa de projetos diferentes, e sim aparecem compromissos estranhos às organizações, e principalmente um caráter financeiro que a representação envolve.

As formas de organização da democratização das administrações públicas, os conselhos populares, não envolvem benefícios financeiros, são de caráter honorífico. Seria no jogo político da disputa de projetos entre a sociedade e o Estado que pautaríamos os embates. Mas isto é, em parte, falacioso no caso das experiências recentes que tenho participado. Não é de hoje a instituição de conselhos, dito democráticos, para legitimar os projetos do Estado. O problema atual, em continuando as inúmeras formas de cooptações, é a diminuição das resistências. 
Uma outra forma de ação é uma disputa há muito existente, desde a constituinte de 1987, referente ao aumento do nível de decisão do município sobre a gestão do espaço municipal. Existem interpretações da importância de fortalecer o poder local, e outras que as autoridades municipais podem estar mais propícias a desvios que autoridades regionais, estaduais ou nacionais. A impressão que se tem é que qualquer autoridade está sujeita aos desvios, e que quanto mais próximo da realidade local, maior a interferência popular como "fiscal do Estado". O poder de interferência popular tem suas limitações, em parte, expostas no parágrafo anterior. Já sobre o nível do compromisso de autoridades mais gerais que as locais, podemos fazer alusão aos inúmeros empreendimentos irregulares implantados, principalmente loteamentos, mas não só. É um "modus operandi" da CDHU - Cia. de Desenvolvimento Habitacional e Urbano do Governo do Estado de São Paulo - a construção e entrega de empreendimentos irregulares, com o aval de todos os outros órgãos estaduais.

Os caminhos perseguidos em uma pesquisa são difusos, incluindo nossos pertencimentos e nossas preocupações em relação ao mundo. Mesmo não sendo, necessariamente, uma 
continuidade as compreensões surgidas em um trabalho são acumuladas com os subseqüentes. No caso desta pesquisa existe um acúmulo muito importante oriundo dos primeiros momentos da preocupação sobre o morar, que foi sistematizado na dissertação "Centralidade e periferia na Grande São Paulo Abordagem crítica sobre o morar na periferia da metrópole", nesta dissertação está definido: "O 'morar' neste trabalho está associado a um ambiente, e o termo ambiente, aqui, deve ser entendido como universo de relações. O ambiente de moradia é um universo de pessoas, objetos e situações que estão numa relação que pode diferenciar-se dos ditames da lógica da mercadoria. O termo possibilidade e outros a ele associados são fundamentais, pois se trata de um limite. O limiar de coisas, ações e situações que não necessariamente significam algo diferente ou em confronto com o hegemônico no sentido dado à história, e ao mesmo tempo podem apontar a diferença. "º

Nesta afirmação temos a possibilidade de no morar existirem momentos conflitantes com o sentido dado à história pelos processos hegemônicos. Com o tempo e o acúmulo de

${ }^{8}$ ROCHA, Alexandre S. Periferia e centralidade na Grande São Paulo. Abordagem crítica sobre o morar na periferia da metrópole. Dissertação de Mestrado. São Paulo: Departamento de Geografia - FFLCH USP. 2000. 
preocupações nas pesquisas ganhou destaque uma citação subseqüente àquela afirmação. Agora com uma potência maior, uma perspectiva de método. Não somente uma metodologia, mas uma maneira de cercar e compreender o "morar" incluindo a possibilidade da descrição como um momento da análise e já implicando a necessidade de ir além da análise por tratar-se de um desvendar de complexidades.

Henri Lefebvre afirma "Naturalmente pode falar-se de 'situação' para o habitante. Habitar é uma situação que implica relações com grupo de objetos, classes de atos e pessoas; esta situação produz determinadas relações em lugar de recebê-las ou percebê-las passivamente. Inverte a relação significantesignificado enquanto o objeto considerado isoladamente como signo (significante) se transforma em significado do habitar quando é referido à situação (por exemplo, o urbano). Esta situação implica ocupar um lugar, a relação com este lugar e com outros lugares (o 'aqui' e o 'em outra parte'). Não vai sem a aceitação de constrangimentos globais, resumidos no plano da cidade, na sincronização das cronias e topias. Os atos e situações não podem ser expressos sem referência ao 'mundo dos objetos', aos lugares, às diferenças de lugares (topias: iso- e 
hetero-), porém também ao possível-impossível: a comunicação perfeita, a expressão total, a transparência das relações, a livre metamorfose das atividades e situações, o não trabalho integral, os momentos puros, o conhecimento íntegro, o prazer ilimitado; em uma palavra, a utopia (presente e ausente, influente com este título, sem a qual não haveria nem ato nem situação) [...] Sem dúvida há menos atos que objetos e menos situações que atos. Somente a estatística comparativa poderia confirmar a hipótese. E, no entanto, há uma complexidade crescente desde o nível de objetos ao de atos e ao de situações." ${ }^{9}$

Tentar localizar e compreender algumas complexidades é um movimento desta tese. Aliás, parte da tese é explicitar situações significativas para a compreensão da periferia metropolitana, em especial os ambientes de autoconstrução.

Vivendo e atuando dentro das complexidades, somente com a preocupação de compreendê-las poder-se-á, imbuído de compreensões críticas dos processos de dominação, exploração e humilhação construir conhecimento a partir desse imediato avassalador que é o cotidiano. A busca na vivência e no vivido de momentos e obras faz parte das utopias necessárias aos

\footnotetext{
${ }^{9}$ LEFEBVRE, Henri. Elementos de una teoría del objeto. De lo rural a lo urbano. Barcelona, Ediciones
} Península. 1975.p.261-262 
pesquisadores implicados com a realidade que se propôs a estudar. "Sim, a vivência é algo vago. Isto é o que reprovam-lhe os caudilhos do saber e os campeões da cientificidade. AtribuirIhe contornos, 'delimitar-lhe' como se diz, já é reduzi-la assimilando-a ao concebível, identificando por hipótese com a forma conceitual. Não é menos criticável a exposição inversa, que projeta a vivência nas profundidades abismais, por demais, difere pouco do primeiro posto que os teóricos do inconsciente o convertem em conceito! O conceito deve mover-se com firmeza antes de aproximar-se da vivência. Quem emprega conceitos deve vestir luva de veludo. O homem de ciência deve aprender a respeitar a vivência, por menor, por mais humilde que seja ante a enorme massa de saber acumulado ... A vivência não coincide com o singular, com o individual, com o subjetivo, pois as relações sociais também são vividas antes de serem concebidas; existe a vivência social vinculada com o individual, porém diferente de sua singularidade." ${ }^{10}$ Não é mais o caso de perguntar sobre um distanciamento necessário entre pesquisador e objeto, e sim sobre a propriedade do arcabouço conceitual assumido para configurar as explicações propostas

10 LEFEBVRE, Henri. La Obra. in La Presencia y la Ausencia - Contribucion a la teoría de las representaciones. México DF: Fondo de Cultura Económica., 1983, p.223. 
pela pesquisa.

Um pesquisador implicado que está dentro do objeto, faz parte dele. Remi Hess afirma "No sentido de implicar-se, a palavra implicação reenvia a uma forma de comportamento do pesquisador que tenta romper a distância instituída entre ele e seu objeto."11 Nesta perspectiva, é um privilégio fazer parte do objeto, significa mais que estar implicado, é ser implicado. Porém fica difícil separar situações e considerá-las externas. Na complexidade crescente dos envolvimentos de pesquisador, morador, profissional, militante não é pertinente descartar as possibilidades que o envolvimento visceral propõe também para uma construção de um pensamento crítico inclusive sobre nós mesmos, numa busca de uma suposta objetividade. Implicação significa, primeiramente, que não se pode isolar certas peculiaridades da pesquisa em si mesmas; que o pesquisador faz parte da pesquisa (no campo, ele é mais um elemento do conjunto, portanto, mais um elemento a analisar) e que ele, consciente ou não, está imerso nessa relação e desempenha um mandato social muito especial. A implicação conduziria ao intelectual implicado, aquele que se aproxima tanto do objeto

\footnotetext{
${ }^{11}$ Baitz, Ricardo "A implicação: um novo sedimento a se explorar na Geografia?” Boletim Paulista de Geografia. São Paulo: Associação dos Geógrafos Brasileiros - Seção São Paulo. 2006
} 
que torna ele mesmo parte da sua pesquisa. Intelectual ciente que sua vida não foi um ocaso e que tampouco foi um acaso a escolha do objeto que ele pesquisa. ${ }^{12}$

Há que se precaver, um risco iminente é o da sobreimplicação: "A sobreimplicação é a ideologia normativa do sobre-trabalho [...] também é possível referir-se a uma ideologia participacionista"13. "Do ponto de vista da análise institucional, a sobreimplicação não só produz sobretrabalho, estresse rentável, doença, morte e mais-valia, como também cash-flow - benefício absolutamente nítido consagrado ao reinvestimento e, portanto, ao crescimento indefinido da empresa-instituição" [...] A morte por trabalho não deveria espantar os pesquisadores sobreimplicados no trabalho do conceito de implicação!"14 "Algumas vezes parece existir uma competição entre quem participa mais [...] Implicar-se não é participar do partido político de manhã, das reuniões do departamento à tarde e da política estudantil à noite, como se

\footnotetext{
${ }^{12}$ Baitz, Ricardo "A implicação: um novo sedimento a se explorar na Geografia?" Boletim Paulista de Geografia. São Paulo: Associação dos Geógrafos Brasileiros - Seção São Paulo N 84. 2006

${ }^{13}$ ALTOÉ, Sônia, (organizagora). René Lourau: Analista Institucional em Tempo Integral. São Paulo: Hucitec, 2004. p. 190

${ }^{14}$ LOURAU, René. Implicação e sobreimplicação in ALTOÉ, Sônia (org). René Lourau: Analista institucional em tempo integral. Hucitec: São Paulo, 2004. Pág. 195 apud Baitz, Ricardo. "A implicação: um novo sedimento a se explorar na Geografia?” Boletim Paulista de Geografia. São Paulo: Associação dos Geógrafos Brasileiros - Seção São Paulo N ${ }^{\circ} 84.2006$
} 
fosse bonito trabalhar ou implicar-se à exaustão (sobretrabalho e sobreimplicação). ${ }^{\prime 15}$

Em 21 de outubro de 2006, fizemos um trabalho de campo em Jandira sobre a implicação como método de pesquisa. A atividade fez parte da disciplina Trabalho de Campo em Geografia, ministrada professora Amélia Luisa Damiani.

Tive a oportunidade de ter acesso aos relatórios elaborados pelos alunos, em grupo ou individual.

Nas aulas os alunos leram o capítulo "A Alienação da Festa" da dissertação de mestrado "Centralidade e Periferia Na Grande São Paulo - Abordagem crítica sobre o morar na periferia da metrópole" na qual fizemos análise do uso político eleitoral das possibilidades de encontro na centralidade da periferia. Também leram e debateram o artigo "A implicação: um novo sedimento a explorar na geografia?"16 com o próprio autor Ricardo Baitz.

\footnotetext{
15“'A sobreimplicação é o plus, o ponto suplementar que o docente atribui ao trabalho do aluno se encontra esmero em seus cadernos (foi assim que minha filha trouxe para casa, triunfalmente, um 21 sobre $20 \mathrm{em}$ matemática, matéria que ela já brilhava). A sobreimplicação é composta igualmente de virtudes exigidas dos empregados, hierarquizadas em grades de avaliação. (...) Trata-se de exigir um suplemento de espírito, garantia de um sobretrabalho diretamente produtor de identificação com a instituição e indiretamente produtor de mais-valia em favor do empregador - e não em favor do trabalhador coletivo, cuja cooperação repousaria minimamente, ainda e sobretudo, na resistência. É a autogestão ou a co-gestão da alienação". (LOURAU, René. Implicação e sobreimplicação in ALTOÉ, Sônia (org). René Lourau: Analista institucional em tempo integral. Hucitec: São Paulo, 2004 Pág. 192. apud Baitz, Ricardo. “A implicação: um novo sedimento a se explorar na Geografia?”. Boletim Paulista de Geografia. São Paulo: Associação dos Geógrafos Brasileiros - Seção São Paulo. 2006)

${ }^{16}$ BAITZ, Ricardo. A implicação: um novo sedimento a se explorar na Geografia? BoletimPaulista de Geografia - Trabalho de Campo. São Paulo: Associação dos Geógrafos Brasileiros. Seção São Paulo N ${ }^{\circ}$ 84 julho/2006.
} 
Foi preparado um roteiro com seis paradas, incluindo uma para almoço:

- O local de encontro em Jandira foi a Praça de Eventos Elias Barjud; Em parte, já conhecida pelos alunos, pois o texto "a alienação da festa" apresenta a área, que em 2000 não possuía nenhuma infra-estrutura. Já em 2006, temos uma praça com uma pista de caminhada de 600 metros, duas quadras poli esportivas, e um vestiário. Ao lado da praça está localizada a Escola Estadual Profa. Josepha Pinto Chiavelli, na qual temos parte da implicação de quem acompanha o grupo, como professor de geografia. E ainda na rua adjacente temos a residência do mesmo. 
Imagem da Rodrigo Gomes Mariano 
- a segunda parada foi numa ocupação à beira do córrego Barueri Mirim, a rua Rodrigo Gomes Mariano - Vila da Amizade na divisa de Jandira com Itapevi. Esta ocupação é resultado de um grande esforço da população, quem ali reside "empurrou o córrego com as mãos", retiravam terra, com pá, enxadão, picareta e carriola, de um barranco da outra margem e aterravam o lado de cá. É mais que esforço físico, é uma história de luta e sofrimento. Inclusive o nome Rodrigo Gomes Mariano, dado à rua, é homenagem ao filho de uma família ali residente, que morreu soterrado no desmoronamento do barranco onde extraíam material para desviar o rio.

- a terceira foi para almoço, na Casa do Norte do Jd. Nossa Sra. De Fátima, ou do Zu. Além da boa comida, tinha-se a oportunidade de observar a paisagem de autoconstrução que conurba Jandira e Itapevi; 


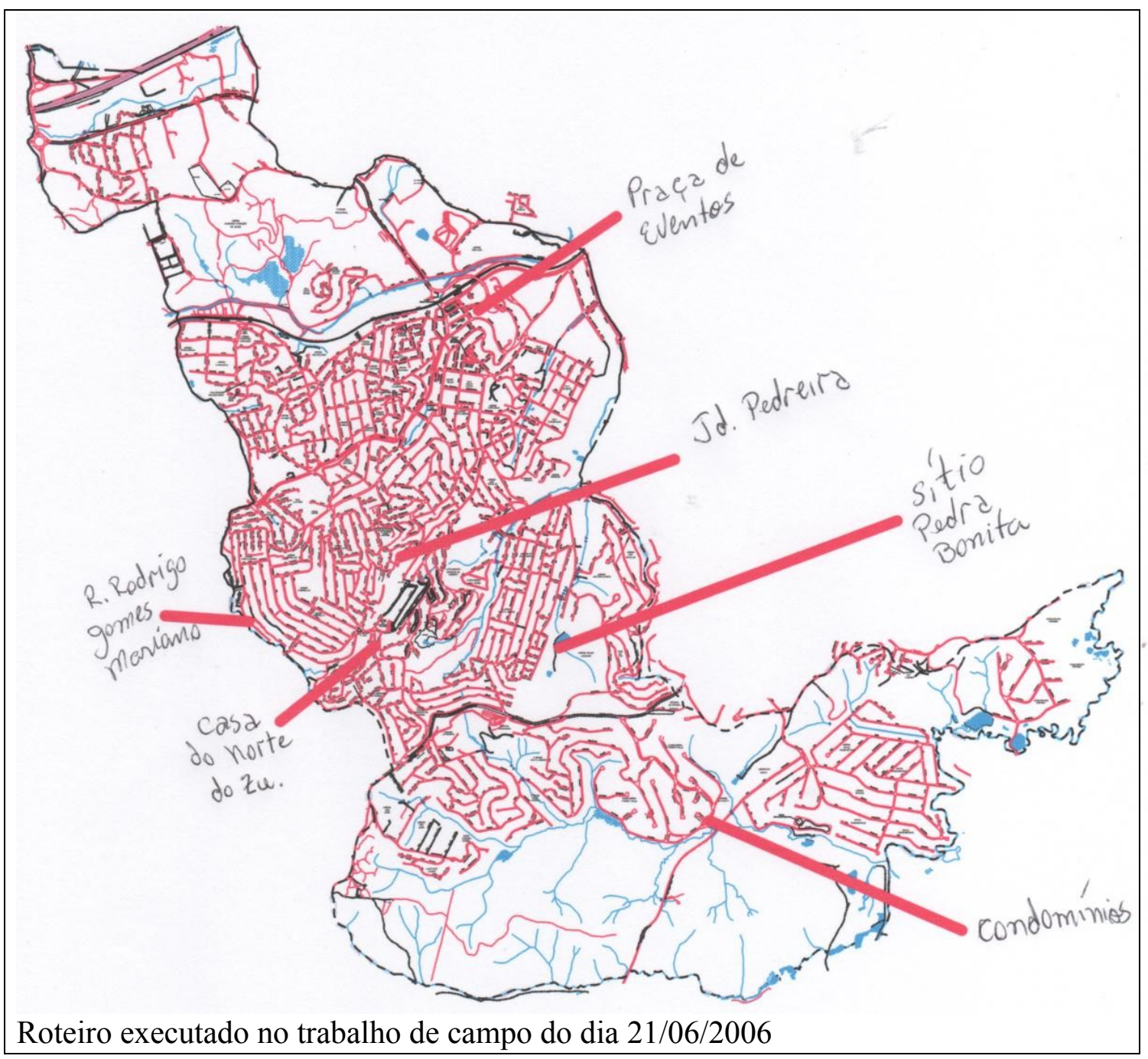

- a quarta parada foi no Jd. Pedreira, a ocupação de uma vertente com vários afloramentos de matacões, que, assim como a Vila da Amizade, faz parte da nossa história de participação nos movimentos sociais da cidade;

- a quinta parada foi no parque Sítio Pedra Bonita, onde além de explicações sobre o processo de loteamento recente e as negociações que permitiram transformar aqueles 103.000 
metros quadrados de área verde em área pública, também foi possível sentarmos no galpão ali existente para discutirmos as questões sobre os elementos da implicação e a particularidade das implicações de minha pesquisa: militante, professor, assessor da prefeitura, entre outras.

- No final do dia ainda conseguimos parar rapidamente junto à portaria do "Forest Hill" - um loteamento de alto padrão com portaria, localizado nas proximidades da divisa de Jandira com Cotia. O objetivo da parada era permitir a comparação entre o padrão das ocupações, permitindo observar ao nível da paisagem as desigualdades sócio-espaciais da cidade de Jandira.

Os relatórios elaborados pelos alunos foram muito significativos na compreensão das limitações da exposição da pesquisa e reveladores de limitações que necessariamente deveríamos ter em pauta. Apresento somente alguns trechos, a título de ilustração, pois não cabe agora exaustão na leitura dos relatórios, embora sejam extremamente significativos. Nestes trechos podemos perceber reflexões sobre algumas situações de Jandira, e é marcante a impressão de sobreimplicação expressas nas observações dos relatórios. 
"Ao chegarmos fomos conhecer o "Pai Jorge", um líder dessa comunidade, um dos representantes da Associação Povos Unidos (local) e "mestre" num centro espírita, que fica nos fundos de sua casa. Junto dele estavam mais duas pessoas da comunidade (duas mulheres). Os três formavam um grupo de imigrantes, tendo os três já morado em São Paulo. Contudo uma fala chamou a atenção: uma delas disse gostar mais de Jandira porque lá o imóvel era dela e se sentia mais apropriada do bairro, das pessoas, enquanto em São Paulo, era apenas mais uma, uma "ninguém", morando de aluguel e etc. Por outro lado, a outra mulher disse não gostar dessa cidade, se utilizava da expressão "lá em Jandira...". Salientou também que precisávamos saber que "Jandira não existia", que era um nada, sem representação, sem governo, enfim, o caos, o nada."

"Afirmou que os projetos são decididos apenas pelo Alexandre e não pela Prefeitura, sem discussão e tudo é como ele quer, acha melhor. Esse foi o início de uma discussão entre os dois, em que o Alexandre começou, penso, a se tornar um sobre-implicado, pois o foco 
voltou-se todo para ele, no seu papel de planejador e não mais a área em sí, o condomínio, ou o problema de devastação das áreas naturais. Ainda mais por sua intensa participação e envolvimento na cidade, seja como professor, seja como pesquisador, seja como planejador." (FÁBIO)

"Algo marcante colocado por "Pai Jorge" foi a luta por regularização da rua para que as casas tenham números e o correio passe por lá, podendo receber cartas de familiares e amigos, mas, mais do que isso, segundo "Pai Jorge", para que possam pagar impostos. Ele e alguns dos outros moradores presentes vêem o pagamento de impostos como um dever e um direito, para poderem continuar reivindicando políticas públicas para a melhoria do local de moradia deles. Ou seja, há a percepção de que precisam pagar para o Estado para que possam exigir algo em troca, direitos básicos como asfaltamento de rua, postos de saúde e outros."

"A produção desigual da cidade - que configura sua crise - nos impõe viver desigualmente a cidade; viver pelos seus fragmentos. Isso se agrava se falamos da 
periferia. $\mathrm{O}$ alto preço das passagens de ônibus contribui para que se reduzam os espaços de uso da cidade. 0 limite é imposto pela compra dos trajetos de ida e volta; o deslocamento se torna impossível." (CAROLINA, LÉA, RENATA)

"... O implicado é o Alexandre e não nós. Iremos apenas enxergar Jandira através da implicação dele..." (ALEKSEI, BRUNO, IVAN, MILENA, MITINOBU)

"Por ser morador de Jandira, militante, professor e funcionário público, Alexandre encontra sérias dificuldades em sua pesquisa: em um primeiro momento, precisava desvencilhar-se de suas percepções prévias sobre a cidade, construídas por ser morador e ativista; ao mesmo tempo, não pode deixar essas impressões de lado, já que precisa estar imerso no tempo social de Jandira para fazer pesquisa. Somado a isto, há a necessidade de não se perder em seus papéis, que são funcionais e não permitem confusão; é claro que 0 professor pode falar de sua pesquisa e 0 pesquisador pode usar sua experiência de morador para escrever seu texto, mas há limites nessas 
transferências. Por conta disso, Alexandre encontra problemas na hora de escrever, uma vez que sua autocrítica enquanto pesquisador se dá em diferentes esferas, e por vezes acaba por achar-se sem saída em relação à pesquisa. De seu depoimento, pode-se notar a força que a sobre-implicação pode ter no caso de um pesquisador extremamente imerso em seu objeto de pesquisa; ao mesmo tempo, os extratextos e os intertextos a todo tempo nos remetiam a suas práticas de professor e de funcionário, uma vez que em muitos momentos do texto podemos encontrar referências a esses momentos."

"Desta maneira, ao trazer o processo de pesquisa para o texto da pesquisa, trazemos também todos os problemas encontrados no processo e, muitas vezes, algumas posições políticas que são frutos de nossa prática enquanto pesquisadores implicados e não de uma construção ideológica que ultrapassa teoria e prática. A implicação tem seus riscos, portanto, e é necessário conhecê-los quando da escolha desta como método de pesquisa de campo - ao mesmo tempo em 
que podemos reconhecer na pesquisa do Alexandre sobre Jandira aspectos que somente um pesquisador implicado poderia conseguir compreender." (DANILO)

"Esta relação mais íntima com o objeto de estudo, muitas vezes sendo parte deste, trouxe ao pesquisador a necessidade de adotar uma outra postura no encaminhamento de seus trabalhos de campo e no desenvolvimento de sua pesquisa. A proximidade com 0 objeto de estudo dificultava a percepção e o tratamento do objeto pesquisado, assim, a implicação aparece como uma alternativa de pesquisa. Isso porque ela pressupõe o pesquisador como parte integrante do objeto de análise." (JANE, LETÍCIA, LÍDIA, LUIZ TADEU)

"Não que isto aconteça sem conflitos, pois ser um pesquisador implicado é olhar para seu objeto e para você mesmo, não sem criticar e posicionar-se, revendose constantemente o que levaria o pesquisador a uma sobreimplicação." (IGOR, MARIA LUIZA, RICARDO,

\section{ALEXANDRE)}

"Em linhas gerais, a implicação busca romper com a separação entre sujeito e objeto que os pesquisadores 
geralmente adotam em suas premissas metodológicas e em seus trabalhos: é a busca da coincidência entre ambos (sujeito e objeto) que iria gerar uma autoreflexão do pesquisador e uma relação de intimidade com aquilo que ele estuda."

"...Aquilo não era cotidiano, era momento..."

"Despedimo-nos da Rua Rodrigues Mariano - nome dado em homenagem ao menino da comunidade falecido durante o trabalho de aterro da rua - e nos dirigimos ao ônibus, atentando, no caminho as diversas formas com que esta população vive e gera economia: bicicleteiros, costureiras, proprietários de pequenas lojas...Uma infinidade de trabalhos e de ocupações em pleno dia de sábado." (KAUÊ)

A sobreimplicação pode ser um limitador para a construção crítica do pensamento, pode configurar-se um viés ideológico, motivado por outros comprometimentos além ou aquém da realidade. Mais do que nunca é necessária a crítica sobre nós mesmos.

A implicação permite compreensões além das pseudo neutralidades, objetividades, porém devemos atentar para 0 
real; é dialética a procura de desvendamentos das complexidades crescentes dos objetos, atos e situações. A base para a compreensão é o movimento do real. Como pesquisador é possível situar parte dos movimentos, seccionar deve ter critérios, a busca deve ser a totalidade. "A cidade, superobjeto espacial, supersigno, somente é acessível através de múltiplos percursos, seqüências temporais articuladas a seqüências espaciais, passos através dos objetos, que podem expressar-se (pela palavra) em discursos múltiplos. Seu estatuto como objeto não parece fácil de definir." ${ }^{17}$ Mesmo a interpretação de uma fala, por mais singela, deve-se tomar todos os cuidados nas construções das constatações. Existe necessariamente uma situação de delicadeza quando a busca do real passa pelo vivido. Dada a possibilidade de sobreimplicação, são ainda mais complicados os caminhos assumidos nesta pesquisa. Existe uma possível fragilidade: a sobreimplicação.

Apenas os receios e suspeitas não são suficientes para desconsiderar a potência da implicação, apeguemos ao método, à visão do mundo, às construções teóricas, mais do que nunca não há espaços para o ecletismo; se o compromisso é com o Península. 1975, p255 
real, admitamos as fragilidades, e busquemos mecanismos de procedimentos que contribuam de diferentes maneiras na busca dessas totalidades, isto mesmo, é plural, é aberta a realidade. É um leque de totalidade, ou melhor, a totalidade é aberta, toda arrogância em cercá-la imprime-Ihe maiores amplitudes.

Diante destas preocupações pode-se acrescentar a discussão elaborada por Lefebvre sobre o "os marxistas e a noção de Estado":

"Todo homem político, até nova ordem, é um homem de Estado, é um homem que atua politicamente, seja dentro do marco de um determinado Estado, seja para modificar este marco institucional. Porém um homem de Estado não é necessariamente um homem do Estado. Vou explicar-Ihes em seguida o sentido desta distinção que faço. Considero que há duas espécies de homens políticos: os homens do Estado e os homens de Estado, assim como há duas espécies de sábios, duas espécies de economistas, de sociólogos ou de historiadores. Existem aqueles que aceitam o Estado existente como um dado central das ciências sociais, e que pensam em função desse dado e em função do 
mesmo lançam todos os problemas relativos ao conhecimento da sociedade, às ciências e a mesma realidade. E há outra espécie de sábio: Os que de uma maneira direta ou indireta põem em questão as instituições existentes, e que partem de um estudo científico da realidade, da vida e da prática social para lançar o problema do Estado, o que entranha uma crítica do Estado existente." pp.62-63

"Esta análise das instituições - algumas das quais estão esclerosadas e mortas, enquanto que outras são discutíveis, porém suscetíveis de transformação; algumas com futuro e outras a se criar - esta análise é parte integrante do pensamento político socialista. Se não partimos desta crítica do aparato estatal existente, nos movemos simplesmente dentro do marco da realidade existente, não nos propomos a mudá-la, e de nenhum modo merecemos o título de socialistas, qualquer que seja nosso conhecimento e nossa habilidade." (p.64) [...] "Por conseguinte, creio que a condição de socialista e de homem do Estado são incompatíveis. [...] O homem político socialista conhece 
o manejo das forças sociais, conhece a dinâmica das forças sociais dentro do marco do Estado existente. Se propõe utilizá-las para modificar este Estado. E por isso pode ser um homem de Estado sem ser um homem do Estado." (p.65) 18

Amélia Damiani sobre o mesmo livro destaca:

"Não somos um Estado Nação clássico, como a França. No Brasil, trata-se de um Estado forjado acima da sociedade e, historicamente, houve e há a busca por constituir os intermediários entre a sociedade e esse Estado; daí, dentro do projeto político, do modo como aqui o concebemos, a reiterada presença da busca por espaços políticos dentro e a partir do Estado. Aqui, também, o papel econômico do Estado é muito importante. E a produção do espaço, atualizando a economia nas e das metrópoles, face às exigências de concorrência e inserção internacionais, nas últimas décadas, torna expressa, mais uma vez, essa parceria, para aumentar a composição orgânica do espaço, com vistas a um maior desempenho econômico, que,

${ }^{18}$ LEFEBVRE, Henri. Los marxistas y la nocion de Estado. Buenos Aires: CEPE, 1972. 
ideologicamente, é definida como política econômica sustentável. (Ao estabelecer o nexo entre a constituição do Estado e o desenvolvimento da acumulação capitalista, Lefebvre esclarece diferenças entre os países, por exemplo, o desenvolvimento econômico na Inglaterra teria precedido aquele do Estado. Neste sentido, localiza um caso limite de atrelamento: 'E chegamos finalmente a um caso limite, o dos países subdesenvolvidos, onde a constituição do Estado precede ao crescimento econômico (...) vão iniciar a industrialização e já têm seu Estado, seu aparato estatal.' (LEFEBVRE, Henri. Los marxistas y la nocion de Estado. Buenos Aires: CEPE, 1972, p. 72.) $)^{\prime 19}$

Em termos de implicação, ou de análise institucional, considero mais apropriado encarar que parte desta pesquisa também é de um homem de Estado. Que atua ao nível municipal. O município é um ente federado conforme a Constituição do Estado brasileiro; é o âmbito do Estado que o fracionamento da gestão do território permite.

\footnotetext{
${ }^{19}$ Damiani. Amélia Luisa. A metrópole na dialética entre o território de ação estatista e o espaço de projeto político. Mimeo. p. 09
} 
Uma pesquisa implicada, com um envolvimento de um homem de Estado, que também considera: "O conhecimento do Estado é o dado essencial da ação política"20. Eis o desafio desta pesquisa.

Aos riscos da sobreimplicação se sobrepõe a necessidade da ação política. Necessidades ao nível da sobrevivência, que em Jandira se enfrenta, tornam premente essa presença social e política. Assim, tento me fazer consciente, o tempo todo buscando a apropriação possível, o projeto, em embate com as formas de alienação próprias de nosso tempo. Pratica e teoricamente, sou movido por um projeto social e político, não irrisório, do que pode ser a periferia metropolitana hoje.

Do ponto de vista da sobreimplicação, conceitualmente, ela deve sofrer alterações, dado o contexto da periferia metropolitana de um país periférico, cujo Estado compõe significativamente a economia. A ação política de homem de Estado deve ser interpretada aqui nos planos dos atos e das situações em produção, mais do que enquanto objetos produzidos, inclusive pela circunstância da mobilidade da qual falava no início do presente capítulo.

\footnotetext{
${ }^{20}$ LEFEBVRE, Henri. Los marxistas y la nocion de Estado. Buenos Aires: CEPE, 1972. p60
} 


\section{O território de Jandira}

A tese não é um estudo sobre o município de Jandira, porém, pareceu apropriado situar Jandira aos leitores, pois contribui no entendimento do lugar de envolvimento do pesquisador.

Durante 0 processo de elaboração do Plano Diretor Participativo de Jandira foi contratada a Fundação Para o Desenvolvimento da UNESP (FUNDUNESP) para assessoria técnica no desenvolvimento do plano, como coordenador técnico indicado pela prefeitura houve a oportunidade de participar de todo o processo desde o levantamento de dados às audiências públicas, e baseado nas informações coletadas pretende-se apresentar resumidamente a conformação territorial do município. O tratamento das informações bem como as constatações são resultado de um trabalho coletivo, envolvendo vários profissionais com compreensões diferentes, e por respeito a um trabalho coletivo optou-se por apresentar aqui o resultado dos estudos e não a compreensão do pesquisador que redige esta tese. Algumas afirmações constantes nestes trechos não 
são, necessariamente, assumidas nesta tese, porém contribuem na demonstração das possibilidades de diferentes entendimentos de uma mesma realidade. A utilização dessa documentação municipal, o plano diretor, também, define a linguagem e o modo de operar do Estado, através dos municípios.

O município de Jandira localiza-se na sub-região Oeste da Região Metropolitana de São Paulo com acesso pela Rodovia

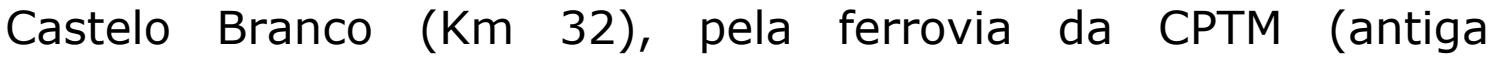
Sorocabana), pela Av. João Balhesteiro que margeia a referida ferrovia, interligando Jandira com Barueri e pela estrada Fernando Nobre que liga o município à rodovia Raposo Tavares. Faz divisa com Barueri, Itapevi, Cotia e Carapicuíba.

Possui $22 \mathrm{Km}^{2}$ segundo Instituto Geográfico e Cartográfico - IGC, porém, conforme o IBGE, a área do município é $18 \mathrm{Km}^{2}$. Através de um levantamento aerofotogramétrico realizado em 2005, constatou-se $17,5 \mathrm{Km}^{2}$. Desde 1964 a totalidade do território é considerada urbana.

É recorrente a pergunta sobre o porquê de Jandira ter perdido quase $5 \mathrm{Km}^{2}$, quando na realidade houve um avanço tecnológico que permite maior precisão no sensoriamento remoto. Na década de 1960 o IGC utilizou cartas na escala 
1:100.000 para elaborar as descrições dos limites dos municípios. Na década de 1970 a Emplasa realizou um levantamento da Região Metropolitana de São Paulo na escala 1:10.000, esta com muito mais detalhes permitiu ao IBGE aferir com muito mais precisão as áreas dos municípios da Grande São Paulo. E em 2005 com fotografias aéreas na escala 1:1.000 e seguindo as descrições da lei de emancipação do município (1964) constatou-se $17,5 \mathrm{Km}^{2}$ de área do território de Jandira. Mas a acusação de que esta gestão do governo municipal teria perdido quase $5 \mathrm{Km}^{2}$ persiste, inclusive com candidatos de oposição prometendo recuperar se eleito for.

A diferença entre a compreensão técnica e o senso comum sobre o espaço e o território é notória nesta situação, inclusive, sugerindo o comparecimento na Câmara Municipal para esclarecimento sobre essa perda: "porquê Jandira perdeu quase $5 \mathrm{Km}^{2 ? "}$. Assim, começamos, reiteradamente: "não é perda de território, é resultado de melhoria nas técnicas de representação do espaço..." Mas o inquiridor afirma entre os dentes, "ta, mas não me convenceu". De qualquer forma, no limite de destituição de pertencimentos, ainda, resta a imagem de uma certa potência, através do tamanho do município, no âmbito de 
terreno de possíveis atividades de "desenvolvimento", que sugerem, pela ausência, essa percepção de perda.

Conforme estimativa do Instituto Brasileiro de Geografia e Estatística a população contava 113.323 habitantes (estimativa IBGE/2006) com uma taxa de crescimento anual de 4,33\% IBGE 91/2000. Neste mesmo período o crescimento da Região Metropolitana de São Paulo foi em média 1,64\% . Portanto, considerando a área atualizada em 2005, a densidade demográfica de Jandira é 6.476 habitantes por quilômetro quadrado. O predomínio na população é de jovens, $41 \%$ tem menos de 20 anos, sendo $11 \%$ entre 15 e 19 anos; de baixa escolaridade, média de 6,89 anos; e apenas 19\% da PEA, cerca de 12 mil pessoas, têm mais de 10 anos de estudo. Apenas cerca de 2,1 mil jovens de 15 a 19 anos tem escolaridade média completa.

Com esta alta densidade populacional, mais de $6 \mathrm{mil}$ hab./km²; possui uma topografia com predominância de morrotes e morros baixos, com vales incrustados. Possuindo, portanto, uma grande quantidade de vertentes e na sua ocupação predomina o padrão de urbanização horizontal com lotes médios de $125 \mathrm{~m}^{2}$ a $250 \mathrm{~m}^{2}$, sendo que, na maior parte da 
cidade, a autoconstrução foi a alternativa dada pela população, principalmente pelas limitações financeiras da população, que conforme a Fundação Seade (2000) 64\% dos chefes de família recebem de 1 a 5 salários mínimos e a renda per capita era $R \$$ 775,72 .

Conforme o mapa de aptidão física para ocupação elaborado pela FUNDUNESP, o território do município possui grande parte de sua área com alguma restrição para ocupação. Cerca de $50 \%$ do território está classificado como áreas com restrições localizadas onde predomina de declividade de $20 \%$, com "condições topográficas predominantemente favoráveis, com alguns setores problemáticos (declividades maiores que $30 \%$ e cabeceiras de drenagem) que exigem cuidados especiais de projeto de implantação". 
Mapa de aptidão física 
A terça parte da área densamente ocupada está classificada como áreas passíveis de ocupação com sérias restrições, onde predomina declividade de 30\% caracterizada como "condições topográficas desfavoráveis em muitos setores de encostas que impõem diretrizes rígidas de projeto e implantação."

Mesmo ocupando menor área do município, as áreas com severas restrições à ocupação são muito significativas, pois ocupam parte da área densamente ocupada do município. Nestas não temos o problema da declividade, porém estão sujeitas a inundações com "solos com baixa capacidade de suporte" e "dificuldades para implantação das obras de saneamento, edificações e sistema viário".

O interessante na obrigatoriedade de elaboração de plano diretor instituída pelo estatuto da cidade é a constatação que a cidade acontece independente das limitações formais ou naturais apresentadas como desafios aos moradores, enquanto que ao nível técnico são impedimentos ou restrições. Se seguirmos à risca o mapa de aptidão física a constatação possível é que a maioria da ocupação do território jandirense é incompatível. 
A forma como o território do município foi ocupado permite aferir três macrozonas distintas: Zona de Uso Predominantemente Industrial - ZUPI, no norte do município, com cerca de 140 indústrias ( $80 \%$ do total); Zona Intermediária, concentrando a maior parte da população $(90 \%)$ nos bairros e loteamentos existentes com uso misto; e a maior parte dos núcleos habitacionais precários (14) em áreas públicas ou privadas, em grande parte considerada restritiva ou inadequada para uso habitacional (risco de inundação/deslizamento); faltam áreas livres para expansão da ocupação urbana, e a Zona Sul (Condomínios) ocupa $1 / 3$ da área do município com baixa densidade populacional e rendimento superior a $10 \mathrm{s.m}$. Edificações com alto padrão construtivo. 


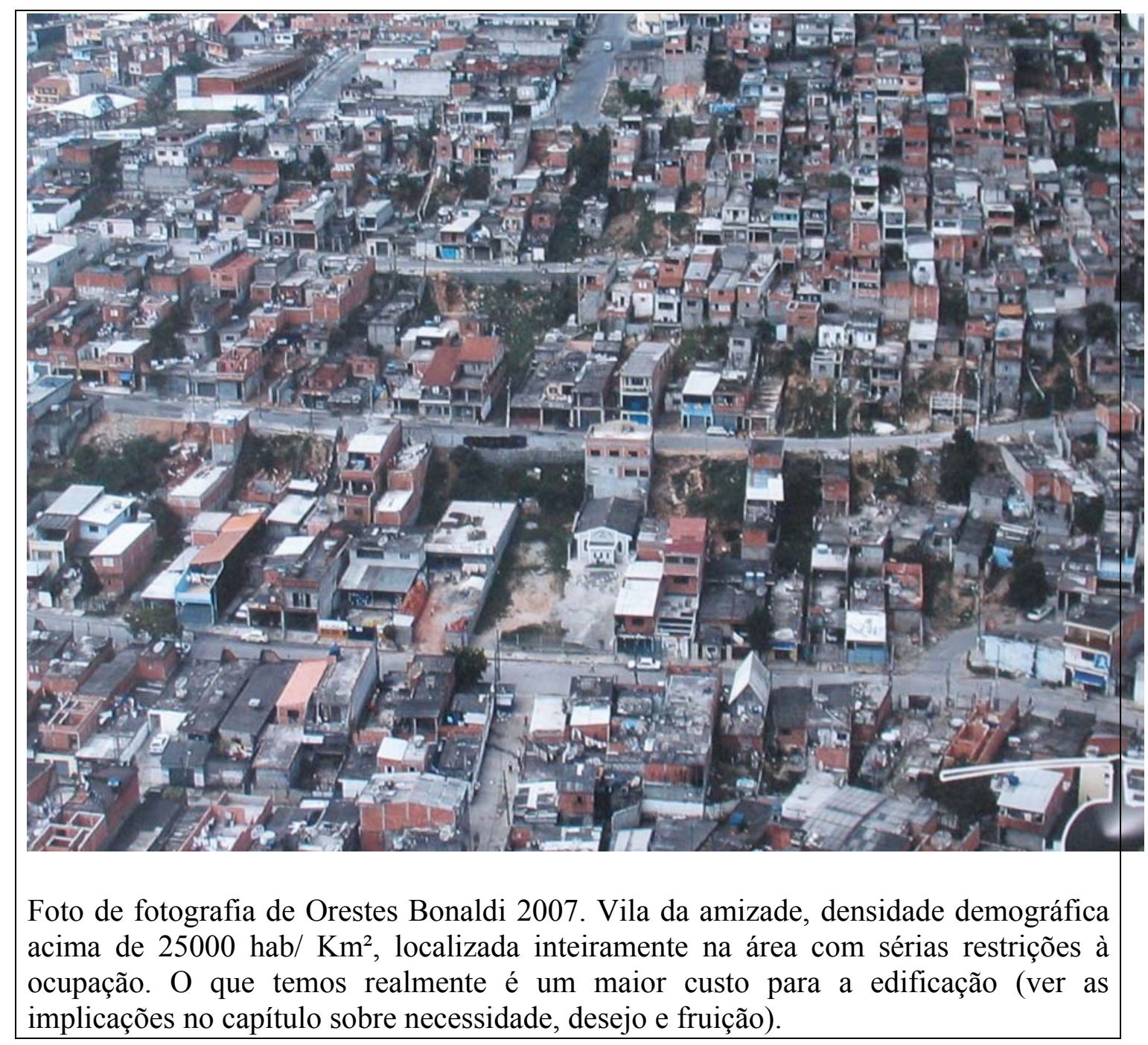

A primeira fase de elaboração do Plano Diretor Participativo foi chamada de "Leitura Técnica da Cidade" e nela foram elaborados, entre outros, dois mapas temáticos um sobre a cidade formal e outro sobre a cidade real. O primeiro aplicando as poucas e defasadas legislações existentes sobre o uso do solo e o outro procurou retratar os usos existentes independentes da 
lei. As macrozonas que ora detalharemos são resultado da interpretação destes dois mapas.

\section{Macrozona Norte}

Localizada na porção Norte, na bacia do rio São João, ocupando cerca de $1 / 3$ do território do município, com população estimada de 4.352 habitantes (PMJ com base IBGE/2000).

Possui 1.103 domicílios (estimativa da Prefeitura com base no IBGE 2000).

É delimitada como zona de uso predominantemente industrial - ZUPI, instituída pela Lei Estadual no 1817/1978 com lotes que variam de 500 a 15 mil m², onde se localiza o parque industrial da cidade.

As140 indústrias (80\% do total) geram 5.061 empregos (60\% do total) conforme EMPLASA/2002. A empresa POLICON S/A. possui um novo loteamento industrial aprovado em 2005, com 63 lotes de 3.800 a $16.800 \mathrm{~m}^{2}$. Este loteamento possui 02 áreas institucionais, sendo que uma é a ocupação do morro do bairro Jd. Ouro Verde. 
Incrustados temos três núcleos residenciais de padrão popular, além do Jd. Ouro Verde existem o Jardim Alvorada no extremo Norte e Jd. Neuza/Vila Márcia na divisa com Barueri.

Foi constatada a existência de núcleos habitacionais precários (Núcleo Alvorada; Rua das Cerejas; Ouro Verde e Antônio Bardela);

Próximo à estrada de ferro, e portanto no limite entre esta zona ao norte e a zona intermediária, existem equipamentos públicos de lazer, esporte e recreação, sendo um conjunto de quiosques com churrasqueiras e play ground chamado de Cidade da Família; 3 Campos de Futebol e Pista de Motocross. 
Mapa macro zoneamento 
Disponibilidade de áreas não parceladas em especial na divisa com Itapevi e Barueri. Ainda também vazia está a área do antigo lixão desativado e, dado o uso contaminante que teve, somente poderá ser destinada a parque.

É uma área predominantemente industrial consolidada, com indústrias de grande e médio porte, dotada de infraestrutura urbana a ser qualificada.

As áreas residenciais de padrão popular com a presença de núcleos habitacionais precários necessitam ser qualificadas através de melhorias urbanas e da regularização fundiária;

Em 1969, através da lei municipal 182, a porção norte do município (ao norte da Estrada de Ferro Sorocabana) foi definida como ZUPI - Zona de Uso Predominante Industrial. Em 1978, com a lei estadual 1817, foi instituído o Zoneamento Metropolitano e este aplicou a lei municipal 182 para definir a área industrial de Jandira, dentro do zoneamento da Grande São Paulo.

As áreas residenciais existentes ao norte da antiga Estrada de Ferro Sorocabana não são resultado de nenhum processo de disciplinamento do uso do solo, pelo contrário, ocorreram à 
revelia da legislação. Inclusive, foi foco de polêmica nas audiências públicas, pois agora estão mapeadas e fazem parte da lei, e alguns vereadores questionaram o uso residencial na área de ZUPI, "em detrimento da indústria que gera emprego e receita". E foi esclarecido que a lei não prevê o crescimento da área residencial nesta região, apenas regularia os usos já existentes.

As macrozonas são um retrato momentâneo do território, os usos existentes, no momento dos estudos para elaboração da lei. As dinâmicas sociais e os movimentos possíveis não serão restritos, nem ao nível formal. Em 2005, foi aprovada na Câmara Municipal a mudança de zoneamento de uma área de 40.000 metros quadrados, na área de ZUPI, para a implantação de um conjunto de torres residenciais. Dependendo do conjunto de forças, é a lei que busca se adequar. (Alexandre não tem 3.a pessoa do singular para adequar)

\section{Macrozona intermediária}

Localizada na bacia do rio São João, entre a ferrovia da CPTM e a Estrada Barueri-Itapevi. 
Com uma população estimada de 84.524 habitantes, representando mais de $90 \%$ da população total do município (conforme prefeitura com base no IBGE 2000). Também por estimativa calcula-se 22.600 domicílios (Prefeitura/IBGE 2000).

Apresenta alta densidade populacional e construtiva, com escassez de áreas verdes e grande impermeabilização do solo, exceto Sítio Pedra Bonita que abriga remanescente de vegetação significativa.

Predomina o padrão de urbanização horizontal com lotes médios de $125 \mathrm{~m}^{2}$ a $250 \mathrm{~m}^{2}$ na maior parte da cidade e de construções de padrão médio e popular em grande parte pelo sistema de autoconstrução.

Tendência à verticalização das construções residenciais (predomina 3 a 4 pavimentos), muitas vezes geminadas e em lotes de dimensões reduzidas.

Grande irregularidade nos loteamentos existentes, sendo apenas 10 considerados regulares na macrozona Intermediária e 64 apresentam alguma irregularidade.

A maioria dos estabelecimentos comerciais e de serviços está dispersa nesta macrozona, em especial no Centro e nas centralidades de bairros e corredores locais e regionais. Assim 
como a maior concentração de usos institucionais localizados também estão na área central de Jandira e corredores de comércio e serviço.

O sistema viário é caracterizado por ruas e calçadas estreitas, sinuosas e a maioria com pavimentação asfáltica. E em relação ao transporte há que se destacar a existência de duas estações ferroviárias da Companhia Paulista de Transportes Metropolitanos-CPTM, estações Jandira e Sagrado Coração.

Também é nesta macrozona onde está localizada a maior parte dos núcleos habitacionais precários existentes na cidade, totalizando 14 núcleos em precárias condições de moradia e com deficiência no acesso à infra-estrutura urbana, em especial esgoto e drenagem. Os 03 maiores são: Pedreira com cerca de 750 moradias; Vila da Amizade com cerca de 700 moradias; e Amaralina com cerca de 300 moradias. Esses núcleos foram classificados em: favelas (ocupação espontânea sem infraestrutura) e ocupações irregulares (áreas com investimentos em infra-estrutura). 
Mapa faixas de renda 
Mapa regularidade de loteamentos 


\section{Macrozona Sul}

Localizada na bacia do rio Cotia, com a presença de condomínios e loteamentos residenciais fechados, ocupa outro terço da área do município com baixa densidade populacional.

Predomínio de população com renda superior a 10 salários mínimos e nível de escolaridade superior (IBGE/2000).

Os lotes residenciais variam de 300 a mais de $1000 \mathrm{~m}^{2}$ com casas unifamiliares de médio a alto padrão construtivo.

Há também a presença de uma área residencial de padrão popular nas proximidades das ruas Silverstone e Lê Mans, que abriga cerca de $10 \%$ da população desta região, de baixa renda, com carência de infra-estrutura urbana e equipamentos públicos, em especial na área do conjunto habitacional Jandira B (CDHU).

Há remanescente de vegetação e glebas ainda não parceladas e não ocupadas;

Segundo levantamento nas imobiliárias locais, o preço do $\mathrm{m}^{2}$ do terreno nesta região é menor que nas demais áreas da 
cidade. Há grande interesse do mercado imobiliário, voltado às classes A e B, trata-se de especulação imobiliária;

Segregação sócio-espacial: o sistema viário não é integrado ao restante da cidade; há ausência de transporte público municipal;

Os loteamentos residenciais fechados não deram nenhuma contrapartida em compensação das áreas públicas internas.

Os moradores dos condomínios e loteamentos fechados pouco se relacionam com a cidade de Jandira e geram pouca oferta de emprego para a população local e como receita aparecem somente no IPTU, dado que raramente consomem no comércio da cidade.

A estrada estadual Barueri-Itapevi (SP 274), que secciona o município no sentido leste-oeste, interligando-o com Barueri a leste e com Itapevi a oeste, funcionando como corredor de integração regional, constituindo-se em uma via arterial, acompanha o divisor de águas da bacia do rio São João e a bacia do rio Cotia. Este também é o divisor de duas realidades sociais bem distintas. A parte da cidade que depende quase que completamente em tudo do poder público, dado os baixos rendimentos salariais, a predominância de faixa de renda entre 
0,5 e três salários mínimos, e a parte com alto poder aquisitivo, cercada pelos seus muros nos condomínios e loteamentos fechados. Ao observarmos o mapa da renda das famílias de Jandira percebe-se claramente a segregação espacial dada pela imensa desigualdade social.

Dispersos na Zona Intermediária, há 259 estabelecimentos, a maioria varejista, estando em especial na área central, e também nas centralidades e corredores de âmbito regional e local.

Há maior concentração de área verdes na zona sul, região dos condomínios, com remanescentes de vegetação nativa em bom estado de preservação. A zona intermediária ao contrário apresenta escassez de verde, que se limita a algumas praças públicas. Exceto na região de Santa Tereza na área do Sítio Pedra Bonita.

Conurbado com os municípios de Itapevi e Barueri, apresentando problemas de divisa. Jandira possui ruas e calçadas estreitas, sinuosas, a maioria com pavimentação asfáltica, que somada à escassez de áreas verdes ocasionam grande impermeabilização do solo, problema acrescido pelo pouco investimento em infra-estrutura de drenagem das águas 
pluviais. Falta numeração oficial dos imóveis e emplacamento das vias públicas.

A legislação urbanística era muito antiga, superficial e genérica, não refletindo a realidade do município, e na interpretação da assessoria estas deficiências contribuem para irregularidade.

Segundo o IBGE (2000), o município possuía 24.538 domicílios, a maioria, próprios. Em 1991, totalizava-se 17.192 domicílios, portanto, houve um crescimento médio de $3 \%$ ao ano. Com predomínio na zona intermediária de 0,5 a 3 salários mínimos de renda familiar (conforme mapa da renda familiar). Segundo a Fundação João Pinheiro no ano de 2000 eram 1.243 domicílios em coabitação e domicílios improvisados, este seria o déficit habitacional do município. Porém temos cerca de $12 \mathrm{mil}$ habitantes, 3 mil domicílios, $13 \%$ da população total, vivendo em precárias condições de habitabilidade. São 19 núcleos habitacionais precários. Destes 11 possuem infra-estrutura completa, 05 parcial, 02 sem infra-estrutura e 01 sem cadastro, que ocupam predominantemente áreas de APP - Área de Proteção Permanente -, definidas pela legislação federal como 15 ou 30 metros das margens dos cursos d'água, ou 50 metros 
de raio, quando área de nascente de curso d'água. Três maiores: Pedreira com 750 moradias; Vila da Amizade com 700 e Amaralina com cerca de 300 moradias.

Aproximadamente $70 \%$ dos loteamentos existentes na cidade têm algum tipo de irregularidade (64); apenas 28 são regulares, sendo 12 na zona sul (condomínios); 06 na ZUPI; e apenas 10 na zona intermediária. A irregularidade dos imóveis causa a sua desvalorização e dificuldades no acesso a financiamento.

Entre 1998 e 2006 foram produzidas 572 unidades habitacionas em Conjuntos Habitacionais em Jandira:

- Em 1998 no conjunto Jandira "A", foram 128 apartamentos da Cia. de Desenvolvimento Habitacional e Urbano do Estado de São Paulo - CDHU;

- Em 2002, no Jardim Sagrado Coração, foram construídas 14 casas emergenciais com recursos do tesouro municipal;

- Em 2002, o Condomínio Bela Vista, tendo 100 apartamentos pelo Programa de Arrendamento Residencial - PAR da Caixa Econômica Federal.

- Em 2003, o Condomínio Vitória, com 180 apartamentos, também pelo PAR; 
- Em 2004, foi entregue o Conjunto Jandira "B", com 236 apartamentos do $\mathrm{CDHU}$;

- Em 2002, no Jd. Figueirão, foram 14 casas PMJ/Habitar Brasil.

A equipe técnica do Plano Diretor também apurou que o município possui um Mercado Imobiliário com três sub-mercados identificados:

- SUPERIOR: comercialização de imóveis em condomínios e loteamentos fechados;

- NEGÓCIOS: voltado a galpões industriais e de logística e outro segmento doméstico que atende as demandas locais (comércio e serviços, em especial na região central);

- POPULAR que atende a demanda da maior parcela da população por lotes e locação de moradias.

A fase de leitura técnica do processo de elaboração do Plano Diretor Participativo de Jandira apontou algumas situações econômicas de Jandira:

- A atividade industrial tem peso importante na formação da receita municipal, mas não pondera, expressivamente, na geração de trabalho e renda para o morador local, pois atrai 
mais mão-de-obra especializada. E uma das características da cidade é a baixa qualificação da mão-de-obra.

- Existem programas que objetivam atenuar estes efeitos, entretanto, não há uma avaliação sistemática dos resultados destes programas; em linhas gerais, demonstram-se insuficientes para reverter a situação, (Programa Renda Cidadã, Programa de Erradicação do Trabalho Infantil, Banco do Povo, dentre outros).

- No circuito formal da economia, os dados de Jandira não estão muito distantes da média registrada na Grande São Paulo: em 2002, o rendimento médio de emprego formal era de $\mathrm{R} \$ 1.244,00$ na RMSP e de $\mathrm{R} \$ 922,62$ em Jandira.

- Exclusão da maior parte da PEA - População Economicamente Ativa - do mercado de trabalho dignamente remunerado, alojada principalmente na informalidade, por vários fatores: baixa escolaridade e qualificação profissional, desagregação familiar. (isto é o que aparece, pois essa população está incluída na lógica do processo de exploração do trabalho, que implica em mobilidade do trabalho e sua degradação) 
- Em relação à renda, do total de famílias, cerca de 24,5 mil, 10,12\% percebem de 0 a 1 salário mínimo, 22,79\% estão na faixa de 1 a 3 salários mínimos, e 20,9\% de 3 a 5 . Em resumo, mais de $53 \%$ das famílias percebem menos de 5 salários mínimos e cerca de $12 \%$ não têm rendimentos.

Dados de 2000 e de 2002 apontam que os 174 estabelecimentos industriais empregam 5.061 pessoas, os 259 comerciais (92\% varejistas) geram 1.203 pessoas e os 204 estabelecimentos de serviços empregam 2.039 pessoas; somados aos 1.500 empregados no Setor de serviços públicos o total chega a 10 mil empregos formais.

Pesquisa Origem-Destino, realizada pela Companhia do Metrô em 1997, constatou que a população ocupada em Jandira já era de 27.748 pessoas, significando que a maior parte da população de Jandira trabalha fora do município.

Não há, porém registro da mão-de-obra informal, considerando-se que a PEA do município é superior a $60 \mathrm{mil}$ pessoas.

Em relação a infra-estrutura temos:

- Abastecimento d'água sob responsabilidade da concessionária SABESP, com contrato vigente entre 1976 e 
2006; abastecimento local se dá através de 2 sistemas produtores: Sistema Baixo Cotia, que abastece totalmente a Macrozona Norte e Intermediária e que apresenta problemas quanto à qualidade da água; e o Sistema Cantareira, que abastece parcialmente a Macrozona Sul e atende esporadicamente (sistemas estão interligados) as demais macrozonas, quando há escassez hídrica no sistema produtor Baixo Cotia. Observa-se que os loteamentos de alto padrão resolveram isoladamente 0 abastecimento, através da perfuração de poços subterrâneos;

- A rede de esgoto também está em operação pela concessionária SABESP, contando com rede de afastamento parcial nas Macrozonas Norte e Intermediária, com vários lançamentos a céu aberto em praticamente todos os cursos d'água da Macrozona Intermediária, ausência de coletores tronco no município impedindo o seu tratamento; projetos da concessionária para implantação de coletores-tronco no córrego dos Mateus (projeto em licitação integrante do Projeto Tietê previsto para 2008), e ao longo do rio São João (sem previsão para execução, com demanda incluída no Plano de Aceleração do Crescimento - PAC do Governo Federal). Os loteamentos da 
Macrozona Sul não abrangidos pelo sistema SABESP de esgotamento sanitário;

- A coleta de resíduos sólidos domiciliar é executada 03 vezes por semana, dias alternados. Em localidades de difícil acesso para caminhão compactador estão disponibilizados contêineres, principalmente em assentamentos precários. A destinação final é em Itapevi em aterro sanitário privado licenciado pela CETESB. A pouca coleta seletiva é insuficiente e sem periodicidade. Resíduos da construção civil são depositados irregularmente ao longo de vários pontos da cidade. E os resíduos de saúde possuem coleta e destinação final adequadas;

- A drenagem do município é formada por duas sub-bacias, sub-bacia do rio São João abarcando as Zonas Norte e Intermediária e sub-bacia do rio Cotia, na Macrozona Sul; as principais deficiências de drenagem e escoamento das águas pluviais estão concentradas junto a alguns dos afluentes do Rio São João na Macrozona Intermediária; os problemas derivam do sub-dimensionamento dos canais, ocupação irregular de margens de córregos e sub-dimensionamento de boa parte das transposições junto ao sistema viário. Os cursos d'água a céu aberto (São João, da Divisa e dos Mateus) expõem outro grave 
problema, a intensa poluição hídrica, já que os cursos d'água são receptores dos esgotos sem tratamento produzidos na cidade de Jandira e em Itapevi (caso do próprio Rio São João); alguns córregos têm problemas de enchente agravados pela ocupação irregular nas áreas de preservação permanente (caso da Rua Amaralina); equipamentos de microdrenagem (bocas de lobo e de leão) encontram-se subdimensionados em boa parte da Macrozona Intermediária.

As áreas verdes mais significativas estão na Macrozona Sul, dado que é onde estão localizadas a maior parte das glebas não parceladas. O Sítio Pedra Bonita, na Macrozona Intermediária, é o que possui maior significado, devido à ausência de ruas arborizadas e a histórica depredação das áreas de preservação permanente em sua maioria já ocupadas por favelas ou núcleos habitacionais precários, em sua maioria promovidos pelo clientelismo eleitoral promovido pelos responsáveis pelo poder público. Estes assentados são caracterizados como irregular. Ocupam encostas de altas declividades ou várzeas dos rios e córregos, caracterizando situação de risco. Primamos pela ocupação das cabeceiras e ao longo dos córregos e rios por construções. Independente do 
padrão construtivo ou do uso, sobre os cursos d'água ou em suas margens temos depósito de materiais de construção e postos de gasolina, inúmeras residências inclusive com padrões construtivos elevados. Mas a preocupação principal deve ser com as construções de padrão precário nesta situação, pois pode colocar em risco, além das condições ambientais, a vida dos que aí habitam.

Em relação à mobilidade urbana, a cidade de Jandira possui uma boa cobertura de ônibus municipal e intermunicipal nas zonas Norte e Intermediária. O transporte ferroviário da CPTM, mesmo necessitando modernização, é um elo de integração metropolitana fundamental para o deslocamento dos moradores. A ausência de integração tarifária entre as diferentes modalidades de transporte torna mais oneroso, para os moradores distantes do centro da cidade, o deslocamento intrametropolitano. Esferas de gestão diferenciadas e sem sistema de integração impedem uma maior acessibilidade pelos jandirenses que utilizam tanto o transporte sobre pneus como o sobre trilhos. Em relação aos ônibus pode ser verificado que a freqüência é deficitária; ausência de veículos para pessoas portadoras de necessidades especiais, ausência de 
equipamentos nas vias (pontos de ônibus com abrigo, bancos, etc).

No sistema viário temos a Macrozona Norte seccionada pela Rodovia Castelo Branco - SP-280. A ligação entre a Macrozona Norte e Intermediária pela via de acesso João de Góes e viaduto JMC. Integração precária entre Macrozonas Intermediária e Sul devido ao estrangulamento provocado pelo parcelamento do solo que não levou em consideração as divisas municipais, provocando a situação em que para chegar a alguns bairros de Jandira tem-se que sair dos limites municipais, provocando transtornos principalmente com a ligação entre os bairros pelo transporte público, que passa a ser intermunicipal. Também temos a ligação com Barueri e Itapevi através da Estrada Estadual SP-274. Há necessidade de novas vias de acesso e reorganização do sistema - sinalização, estacionamentos, regulamentações e fiscalização.

São diretrizes estabelecidas no processo de elaboração do Plano Diretor Participativo de Jandira:

- Princípios da política urbana no município de Jandira: fazer cumprir a função social da cidade e a função social da 
propriedade; promover e garantir o acesso à moradia digna; e a gestão democrática e participativa;

- Democratizar o acesso à terra urbana, através da implementação de uma política urbana e fundiária que amplie a oferta de terra urbanizada, com infra-estrutura e serviços públicos;

- Equacionar a política urbana do município no contexto metropolitano e da sub-região Oeste, para a definição do Macrozoneamento, dos sistemas estruturais do viário, do transporte, das questões habitacionais, urbanísticas e ambientais, enfim, para promover o planejamento integrado no âmbito local e regional;

- Fortalecimento da articulação entre os municípios da subregião oeste através da ação conjunta entre os municípios limítrofes para resolução dos problemas comuns em âmbito local, sub-regional e metropolitano;

- Revisão dos limites das divisas municipais, em especial com os municípios de Itapevi e Barueri, com a oficialização junto ao órgão responsável (Instituto Geográfico e Cartográfico IGC); 
- Enfrentar o grande problema da irregularidade da cidade, priorizando áreas de intervenção e investimentos para regularização urbanística e fundiária sustentável, contribuindo para a melhoria urbana do município na sua totalidade, através de: estudo específico que identifique a diversidade de situações de irregularidade dos loteamentos existentes perante PMJ, GRAPROHAB, Ministério Público e Cartórios (jurídica, urbanística e ambiental); e a implantação de programas de regularização fundiária e urbanística;

- Analisar e definir os instrumentos do Estatuto da Cidade a serem implantados em Jandira;

- Proposição de um Macrozoneamento a partir das características e tendências das macrozonas, zonas urbanas e zonas especiais da cidade;

- Promover a melhor integração e circulação no espaço urbano, com a integração das 03 macrozonas da cidade, minimizando a segregação sócio-espacial e a dualidade hoje existente;

- Orientar o uso e ocupação do solo de forma sustentável: preservar as áreas de preservação permanente (APPs) e os espaços públicos de uso comum; fazer cumprir a função social 
da propriedade com o uso dos terrenos e glebas vazios ou subutilizados e combater a especulação imobiliária (Parcelamento, Edificação ou Utilização Compulsórios; IPTU Progressivo no Tempo; Desapropriação e Direito de Preempção).

- Na área territorial do município de Jandira poderão ser permitidos os seguintes usos: residenciais, sendo os usos destinados à moradia unifamiliar e multifamiliar; nãoresidenciais, sendo os usos destinados às atividades institucionais, industriais, comerciais, e de prestação de serviços; e misto, sendo mais de um tipo de uso dentro da mesma zona ou área; em conformidade com a regulamentação em legislação municipal.

- Aproveitamento das áreas melhor providas de infraestrutura: mecanismos de indução e controle do uso e ocupação do solo (IPTU com caráter redistributivo e regularização fundiária).

- Fazer cumprir a função social da propriedade nos terrenos vazios ou subutilizados, possibilitando a construção de equipamentos públicos de interesse da cidade, regularização fundiária, programas habitacionais de interesse social e para 
proteção de área de interesse histórico, cultural e paisagístico (IPTU Progressivo no Tempo e Direito de Preempção).

- Definir diretrizes para a expansão urbana e os parâmetros urbanísticos para ordenar o crescimento da cidade (possibilidade de verticalização e definição de parâmetros para os novos loteamentos).

- Análise prévia dos novos parcelamentos ou empreendimentos pela PMJ com fornecimento de diretrizes em consonância com o PDP.

- Criação de mecanismos de responsabilidade para obrigar a implantação prévia de equipamentos públicos e infra-estrutura urbana para a implantação ou ampliação de empreendimentos e atividades geradores impactos (Estudo de Impacto de Vizinhança).

- Aplicação do Estudo de Impacto de Vizinhança (EIV) para a construção, ampliação e implantação de novos empreendimentos e funcionamento de atividades urbanas causadores de impactos deverá ser regulamentada por lei municipal.

As preocupações e propostas apresentadas pelo Plano Diretor Participativo têm muito claramente uma visão de 
modernização da ação estatista ao nível municipal. A defasagem da legislação municipal em relação às estaduais e federais, em especial, o "estatuto da cidade" - lei 10.257 - é uma das situações estratégicas no processo de produção da periferia. A aparência é de atraso conjuntural, de gestão ou administração. Essa aparência dissimula os vícios e as formas de dominação de uma parcela da metrópole aparentemente atrasada em relação às modernizações da gestão estatista. Agora, com a obrigatoriedade de elaboração do Plano Diretor Participativo, ao nível do formal, criar-se-iam instrumentos modernos de gestão democrática e sustentável dos territórios municipais.

Esta modernização por lei é muito difícil de ser assimilada nos ambientes de autoconstrução, a não ser pelos que já detinham o domínio da produção destes espaços. Loteadores aprovam projetos com maior quantidade de área verde, "preservando" e propondo sustentabilidade ambiental, ao mesmo tempo, seus lotes ganham o valor da raridade, pois, nos ambientes de autoconstrução, espaços não ocupados ou devastados são raros, uma raridade produzida e agora modernizada pelas idéias de sustentabilidade. Esta, antes de preservar, assegura novos discursos para áreas enquanto 
reservas de valor, que acrescem o preço da terra, somente por cumprir a lei. Isto no caso de nossa periferia já é modernização. Incrível, cumprir leis ambientais das décadas de 1960 e 1970 em Jandira é modernização. E, ao contrário, dos comentários de loteadores, é rentável nos negócios.

O termo sustentável das legislações atuais remete tanto ao meio ambiente quanto ao tratamento dado aos lugares de pobreza. Mesmo não sabendo como se propõe a sustentabilidade, esta aparece dirimindo a responsabilidade do Estado na onda do neoliberalismo. Ambiente sustentável pode ser a preservação da fauna e da flora ou lugares de pobreza que não dêem despesa ao Estado, onde as deficiências de acesso ao emprego e à renda sejam resolvidas com criatividade ao nível local. Tem-se a pobreza e a miséria como reciclagem; ações de ONGs ou fundações são reverenciadas como as inovações que a modernização estatista propõe. 


\section{Situações críticas a nós mesmos}

A noção de pertencimento deve ser considerada sob vários aspectos, Lourau, a partir de um esquema proposto por Joseph Gabel, e ao mesmo tempo rejeitando interpretação dicotômica de um pertencimento de exploradores e explorados, sugere que em vez de partirmos de uma "estática social" nos pertencimentos binários entre conservadores de um lado e revolucionários de outro, procura na "dinâmica social" um terceiro componente: a particularidade do conceito de instituição. Os particulares como agentes de transformação institucional.

"Por transformação institucional se deve entender um nível de análise das transformações sociais que... não cobre o conjunto do processo real de transformação social. O modelo institucional tanto fala através de seus limites e necessárias articulações com outros campos quanto através da pertinência de seu campo próprio." ${ }^{21}$

Uma explicação para a teimosia em continuar nas disputas de projetos no governo de Jandira é uma avaliação de

\footnotetext{
${ }^{21}$ ALTOÉ, Sônia, (organizagora). René Lourau: Analista Institucional em Tempo Integral. São Paulo: Hucitec, 2004. p.59
} 
conjuntura e nesta, aparentemente, a possibilidade de contribuição é a melhor alternativa na busca da transformação da sociedade. Por melhor e por mais importantes que sejam as intenções nas disputas dos projetos, sozinho, não conseguiremos contribuir em nada. "Na qualidade de agente de transformação, e mesmo que se leve em conta o papel desempenhado por personalidades determinantes, é sempre como coletivo que o particular se manifesta."22 Portanto, buscamos juntar projetos ou grupos na construção de possibilidades de mudanças.

Uma questão muito complicada ao nível da administração pública é a dificuldade de discussão das diferenças de concepções. É o império do pragmatismo. Toda e qualquer reunião é executiva, raramente prospectiva, é quase exígua a possibilidade de divergência ao nível de teorias. Qualquer compreensão em relação aos fundamentos das situações aparece como "frescura", ou radicalismo de teóricos, interpretado obviamente como arrogância de intelectuais contra as praticidades dos trabalhadores que não fizeram faculdade. É

${ }^{22}$ ALTOÉ, Sônia, (organizagora). René Lourau: Analista Institucional em Tempo Integral. São Paulo: Hucitec, 2004. p.59 
possível imaginar a dificuldade enfrentada para tentar propor a idéia de que a cidade precisa propiciar o encontro, como um dos conteúdos do urbano?

Alunos do ensino médio, dentro das aulas de Geografia, em 2000, já apresentavam a dificuldade de Jandira contemplar o encontro como um dos conteúdos do urbano. Em seminário, alunas da segunda série do ensino médio apresentaram a deficiência de nossa cidade: as alternativas de encontro, separadas da rotina são igrejas, botecos e quadras ou campos de futebol. Um limitador, segundo elas, à diversão das mulheres, dado o fato da caracterização de ambiente masculino dos botecos e do futebol. Resta a igreja como universal.

Existe uma euforia na cidade pela "Festa Junina Municipal", principalmente entre os jovens, fase da vida onde o encontro é muito mais estimulante, principalmente com diversidade sexual. Os estudantes jandirenses, todos os anos, esperam ansiosamente pela festa junina. Fato marcante pela localização da escola Vila Eunice: junto à Praça de Eventos do Município.

Então vamos ver as implicações como presumidamente um agente de transformação (institucional ou não) nesta questão: 
- a Festa Junina é um dos momentos da cidade de Jandira, muito caros aos jovens, e nas várias tentativas de compreender os processos de produção da periferia metropolitana, um dos assuntos da dissertação de mestrado Periferia e centralidade na Grande São Paulo - Abordagens críticas sobre o morar na periferia da metrópole ${ }^{23}$ foi sobre esta festa será apresentado mais à frente alguns trechos da dissertação de mestrado na tentativa de situar o leitor sobre acúmulos analíticos até 2000.

Conseguimos, ínfimas, porém significativas ações: uma compreensão colocada na disputa é o sentido do urbano na periferia metropolitana. $O$ urbano precisa ser mais que infraestrutura, deve privilegiar o encontro. E como os ambientes da periferia são interpretados como universo da necessidade, os investimentos, sempre insuficientes, ficam no âmbito do atendimento das necessidades básicas da população. O discurso é o do direito, mas as atitudes estão ao nível das necessidades elementares. Saneamento básico, asfalto, guia, sarjeta,

23 ROCHA, Alexandre S. Periferia e centralidade na Grande São Paulo. Abordagem crítica sobre o morar na periferia da metrópole. Dissertação de Mestrado. Departamento de Geografia - FFLCH USP. São Paulo: 2000. 
educação, saúde... são prioridades em relação às praças, esporte, lazer.

"...qualquer ação corre o risco de ser percebida como ativismo inoportuno e perigoso, pois perturba o sistema de ação anterior, que tendia normalmente a entropia. Procuremos, no entanto, distinguir dois graus na ação dos agentes de transformação institucional:

a) O espírito de iniciativa acantonado no 'bom espírito' de cooperação, na disciplina 'livremente consentida', na participação integradora, define o dinamismo quanto o 'caráter', a 'personalidade', as 'qualidades sociais'. Se a manifestação de tal espírito não desbordam os quadros estabelecidos da 'consciência profissional', do 'civismo' e dos 'bons costumes', o desejo de realização mais extrovertido será tolerado e mesmo encorajado (às vezes recompensados). 
b) $\quad$ espírito de iniciativa não mais acantonado no ethos cooperativo, porém suspeito de 'espírito mau' e freqüentemente associados a 'problemas de caráter' (insatisfação, agitação, interesses sórdidos, etc). Tal é a maneira como é percebida a ação instituinte ao nível dos indivíduos ou de grupos 'irresponsáveis'."24

No mestrado foram construídas algumas afirmações, hoje, modificadas pelas conversas com os alunos e nossa inserção institucional. Apresento aqui trechos dos capítulos "A alienação da festa" e "A violência como álibi" para facilitar a compreensão do momento atual.

\section{A alienação da festa}

O morar na periferia é estrategicamente dominado pela alienação produzida e reproduzida. Nestas estratégias de dominação cerca-se as possibilidades de apropriação pelo simulacro e pela repetição. Simula-se a

\footnotetext{
${ }^{24}$ ALTOÉ, Sônia, (organizagora). René Lourau: Analista Institucional em Tempo Integral. São Paulo: Hucitec, 2004.pp.60-61
} 
festa e o encontro. O monólogo do poder instituído está constantemente presente no morar da periferia.

A "170 Festa Junina Comunitária, Arraiá do Nho Braz" nem pode ser chamada de comunitária, pois os critérios para a concessão de barracas estavam condicionados ao pagamento de $R \$ 200,00$ para qualquer interessado e $R \$ 60,00$ para escolas.

A escolha dos locais das barracas estava condicionada primeiramente a quem pagou mais. Quem pagou mais (cinco barracas, $R \$ 1000,00$, por exemplo) escolhia antes de quem pagou menos, e as escolas ficaram por último, é obvio. Esta informação obtive, informalmente, com um funcionário do Departamento de Esportes da Prefeitura Municipal de Jandira, que teve uma barraca no "Arraiá do Nhô Braz". Aliás, foi este o Departamento responsável pela organização da festa.

A participação das escolas se dá principalmente pelas comissões de formatura dos alunos. Esta participação acaba sendo usada como legitimação do termo "comunitária" para uma festa que não passa de 
arrecadação e autopromoção das personalidades políticas em concordância com sentido dado ao governo municipal.

Acredito que uma análise sobre a alienação nos termos propostos por Marx também contribua para uma compreensão da realidade metropolitana, e mais uma vez é necessária a contribuição de Lefebvre no meu trabalho: "A alienação não é teórica e ideal, ou seja, não se verifica apenas no plano das idéias e dos sentimentos; ela é também, e principalmente prática. 0 trabalho está alienado: escravizado, explorado, convertido em fastidioso, humilhante. A vida social, a comunidade humana, apresenta-se dissociada pelas classes sociais, desarraigada, deformada, transformada em vida política, burlada, utilizada por meio do Estado. O império do homem sobre a natureza, assim como os bens produzidos por este domínio, está açambarcado, e a apropriação da natureza pelo homem social transforma-se em propriedade privada dos meios de produção. O dinheiro, símbolo abstrato dos bens materiais criados pela mão do homem (isto é, do tempo 
médio de trabalho social necessário à produção deste ou daquele bem de consumo), domina como senhor os homens que trabalham e produzem. O capital, forma de riqueza social, abstração (que num sentido, e tomado em si, não passa de um jogo de escrita bancária e comercial), impõe os seus ditames à sociedade inteira e implica uma organização contraditória desta sociedade: a relativa sujeição e o relativo empobrecimento da grande maioria desta sociedade. ${ }^{125}$

A re-produção das relações sociais de produção implica estes vários momentos e categorias no século XX: o trabalho abstrato, a vida social, o Estado, a propriedade privada, a abstração concreta do dinheiro, o capital. O espaço como "solo da reprodução" é uma realidade contraditória.

O que temos é uma imposição do sentido dado ao encontro nesta parcela da Região Metropolitana de São Paulo. É um domínio da centralidade demandada pelo urbano.

\footnotetext{
${ }^{25}$ LEFEBVRE, Henri. O Marxismo. DIFEL/Saber Atual. São Paulo, 1963.
} 
Nos anos de 1998 e 1999 tivemos o "Arraia do Nhô Braz" em junho, rodeios em setembro e a festa nordestina em novembro. Mas agora, em junho de 2000, a justiça proibiu o uso do termo "Arraia do Nhô Braz" pois caracterizava propaganda eleitoral e a campanha eleitoral somente seria permitida a partir de 06 de julho. É interessante ressaltar que é proibido o uso do exercício de atividades do poder público como propaganda individual e nestes vários "arraiás" esta sempre foi a tônica.

Mesmo sendo proibido o uso do termo "Arraia do Nhô Braz", o apresentador da festa em todas as oportunidades enfatizava o nome do prefeito como o principal expoente daquele evento. Um outro elemento que merece destaque foi a prorrogação por mais um final de semana da "20a Festa Junina de Jandira", que estava prevista para até 02/07/2000, e foi prorrogada para ter como festa de encerramento o dia 09/07/2000, quando ocorre a grande fogueira e a grande queima de fogos. Portanto posterior à proibição de campanha eleitoral. 
Uma outra novidade, além do não uso do termo "Arraia do Nhô Braz" é a exclusão do termo comunitária, a "20a Festa Junina de Jandira" foi terceirizada, não está mais sob a administração da prefeitura, uma empresa de eventos assumiu a organização da festa, não temos nenhuma escola com barraca, nem associação de amigos de bairro, as barracas são de profissionais que viajam pelo estado de São Paulo e outros lugares acompanhando eventos que reúnam multidões em busca de diversão. Os "barraqueiros" profissionais não são uma novidade nas festas patrocinadas pelo poder público de Jandira, a novidade é a extinção dos não profissionais nas barracas da festa. Aliás, na $20^{a}$ Festa Junina o preço das barracas ficou em $R \$ 570,00$ o metro quadrado, como a menor barraca mede $2 \mathrm{~m}^{2}$, o investimento mínimo seria de $R \$ 1140,00$. Uma explicação que consegui com quem montou barraca do lado de fora do espaço reservado para a festa foi que quem recebeu a concessão para administrar a festa possuía mais da 
metade das barracas, e com um preço elevado diminuía a concorrência.

Desde 1998 venho conversando com "barraqueiros" profissionais. O Sr. Vanderlei, que há dezoito anos trabalha com "serviço de bar" em grandes festas, afirmou que as festas de Jandira não são boas ${ }^{26}$, "tem muita meninada", e estes não têm dinheiro. ${ }^{27}$

Um outro elemento importante destacado pelos barraqueiros é o tamanho do sucesso das atrações convidadas, porque juntam muita gente, "em Ribeirão Pires a festa foi boa" as atrações eram: Chitãozinho e Chororó, Leandro e Leonardo, Zezé de Camargo e Luciano, Sandy e Júnior. Ressalta-se ainda que atrações que atraem pessoas mais idosas também "são boas". "O bom é atração para velhos, que levam a família e com isso consomem mais", "quando vem família, eles pegam uma mesa, pedem porção, bebem, e ficam ali um tempo. Agora esta molecada não".

\footnotetext{
26 “As festas boas são as que dão dinheiro, as ruins dão prejuízo".

${ }^{27} \mathrm{O}$ Vanderlei contou, indignado, que chegaram cinco rapazes e pediram um latinha de cerveja e cinco copos descartáveis.
} 
Parece-me fundamental o fato de a juventude dos arrabaldes da metrópole não ser consumidora em potencial, e ao mesmo tempo ser justamente este o público que lota os eventos. Um elemento que corrobora para isso é o fato de que para a juventude o encontro parece ser um grande mote para se deslocar. Em vários momentos percebi jovens juntando "trocados" para comprar algo para comer ou beber (um cachorro quente para dividir para dois, ou uma garrafa de vinho para cinco ou seis jovens), porém é importante registrar que de uma forma ou de outra estavam gastando, e os barraqueiros de fora não tinham nenhum problema em quantos iriam dividir um mesmo produto, o importante era vender.

Há que ressaltar que comida típica de festa junina é muito difícil de achar, mas este ano a grande marca foram grandes barracas de lanches (churrasco, pernil, hambúrgueres e cachorro quente), mas tivemos inclusive barraca de vinho do porto.

As atrações raramente têm alguma relação com a típica música de festa junina, as mais comuns foram o 
"axé music" e o "sambanejo". Grupos de rap da região também apareceram, com o propósito de "dar seu recado", e freqüentemente o apresentador aproveitava para ressaltar a oportunidade que o "prefeito Braz" estava dando para os grupos de rap da região.

Meninas vestidas com roupas diminutas atraíam a atenção dos rapazes, que corriam para junto ao palco para apreciar e tecer comentários sobre o corpo das dançarinas de "axé music". Concurso de danças ou de calouros simulando programas de auditório da TV, onde o prêmio era cesta básica. Estas são atitudes reveladoras dos limites a que estão sujeitados os moradores dos municípios periféricos da metrópole paulistana. As alternativas de divertimento e de encontro são reprodutoras das alienações do cotidiano.

A idéia de festa junina envolveria reuniões anuais, que seriam ímpares no calendário de quem a tem como tradição, porém estes momentos são capturados em situações espetaculares que ao mesmo tempo simulam espetáculos mais gerais, isto é, o espetáculo 
constantemente bombardeado num movimento mais geral que as particularidades dos lugares e das pessoas.

\section{A violência como álibi}

Durante o "Arraiá do Nho Braz", um mês, aos domingos era anunciado com bastante freqüência que a população podia ficar na festa até o fim porque os ônibus circulariam até duas horas da manhã.

No restante dos dias do ano, de segunda à sexta, os ônibus circulares entre os bairros do município de Jandira têm como último horário 23:20h. Os moradores de Jandira que chegam à estação ferroviária após este horário não têm condução para voltar para os bairros mais distantes. A solução é não chegar após este horário, pois além da distância a ser percorrida, correse riscos devido ao ambiente de violência que marca nossas periferias. O toque de recolher nos bairros periféricos é também devido à falta de transporte coletivo.

O limite do horário para o último ônibus leva em conta o horário das aulas nas escolas do município. 
Desconsidera que, mesmo que somente estudantes tivessem necessidade de condução, muitos moradores estudam fora do município. Estes, para não perder o último ônibus, acabam por sair antes do final de suas aulas.

O município conta com escolas de primeiro e segundo graus e uma escola do SENAI, quem faz cursinho pré-vestibular ou algum curso de nível superior deve procurar em Osasco ou São Paulo. Faltam-me dados para dimensionar qual é a demanda populacional nesta situação, mas posso afirmar que ela existe e não é considerada nos horários dos ônibus. A festa autopromocional do Arraiá do Nho Braz pode garantir transporte público no domingo até as duas horas da madrugada, enquanto que no restante dos dias do ano o último carro é as 23:20h.

Apresento esta questão não para questionar o horário dos ônibus nos dias do Arraiá do Nho Braz, pelo contrário, isto deixa claro que quando interessa ao poder público municipal consegue-se interferir nos serviços de transporte público. Existe um vínculo entre 
os proprietários das empresas de transportes urbanos e o poder público. Entre os empresários e os representantes da política oficial municipal a relação é de conivência nos jogos de interesses locais. Estes empresários financiam campanhas eleitorais. No município de Carapicuiba o atual prefeito, Jorge do Poeirinha, é proprietário de empresa de ônibus que serve àquele município.

Existe uma relação clara entre os interesses do capital e dos representantes do Estado. O vínculo entre as empresas de transportes urbanos e as condições de transportes implementadas pelo poder público municipal fica expresso nestes quatro finais de semana de festa junina. Não são as necessidades dos moradores que dimensionam a quantidade e os horários dos ônibus. Os lucros das empresas e a autopromoção dos representantes de seus interesses no Estado são determinantes das condições de transporte.

Um outro sentido da coação é dado pela violência como álibi para a ordem. No Laboratório de Geografia Urbana tive a oportunidade de participar de um grupo 
de tradução e discussão do livro "Du Contrat de

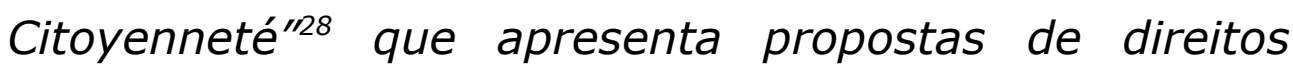
como à autogestão, à informação, à expressão, à cultura, à cidade... Discutir estes direitos numa realidade como a das periferias da RMSP parece não ter nenhum sentido. Pois ao nível dos limites da sobrevivência estes direitos seriam requintes sem tamanho."

Em Janeiro de 2001 assumimos a Prefeitura do Município de Jandira, possibilidade de aproveitar as críticas aos processos políticos do município e por em prática idéias novas, começar a transformar a sociedade através do poder executivo municipal.

Fizemos planejamento estratégico. Definimos metas, marcas, projetos prioritários (em dezembro de 2000) sem ter tido acesso a nenhuma informação sobre a prefeitura, somente o que estava proposto na Lei de Diretrizes Orçamentárias para o ano de 2001. Assumimos o governo com um orçamento de $\mathrm{R} \$$ 33.000.000, sendo que $R \$ 22.000 .000$ já estavam comprometidos com dívidas. A festa junina implicava gastos, não tinha como ser custeada. Mas tinha que ter a grande festa,

\footnotetext{
${ }^{28}$ Groupe de Navarrenx. Du contrat de citoyenneté. Editions Syllepse e Editons Périscope. Paris, 1990.
} 
com a grande fogueira e com a grande queima de fogos, era a $21^{a}$, pois ela existe como uma tradição na cidade.

A partir de então não foi mais o "Arraia do Nhô prefeito", o Prefeito nomeou a "Arraiá do Nho Povo de Jandira", numa ironia política aos seus antecessores, e ao mesmo tempo procurando assimilar as críticas efetuadas durante as disputas eleitorais.

Procurou-se resgatar o caráter de comunitária, criando formas de participação de comunidades, associações de bairros, entidades da sociedade civil, inclusive, com barracas gratuitas, visando uma forma de apoio à organização destas entidades.

Na Escola Estadual Josepha Pinto Chiavelli (Vila Eunice), onde trabalhamos, próxima à área de eventos, um grupo de professores e alunos se dispuseram a organizar e cuidar de uma barraca do setor comunitário da festa, e não precisamos de tráfico de influência ou sorte para conseguir o espaço, não havia quase inscrições. Sobrou barraca.

O setor onde as barracas eram comercializadas esgotou rapidinho, teve que haver sorteio devido à disputa por melhores lugares para garantir clientela.

No setor gratuito, pudemos escolher. E não era mal localizado. Estávamos na parte central da festa junto ao parque 
de diversões. Havia algo estranho, por que as organizações da comunidade não queriam participar? Não podia ser o argumento do refluxo na participação, eram apenas seis meses de uma proposta de governo democrático e popular, existia um ânimo, várias formas de esperança.

O que, de fato, viemos perceber depois era que as comunidades já há muito organizadas não se dispunham a enfrentar o desafio de durante um mês, todas as noites dos finais de semana, até a madrugada, independente do tempo atmosférico, montar e cuidar de uma barraca na festa.

Na escola, para o primeiro final de semana, tivemos a participação de três professores, e aproximadamente 10 alunos, que atenderam ao chamado da escola mais por diversão que por consciência. Mas os que ficaram foram uns bravos. Resistiram.

Nos outros finais de semana a situação piorou quanto ao volume de voluntários na barraca do "Vila Eunice", dos três professores, sobramos eu e professor Jonhson. O outro professor, Benedito, cumpriu ao que havia se proposto, os dias que ficaria como responsável, esteve até o limite do horário do ônibus, dado que mora em um bairro distante do município de Itapevi. 


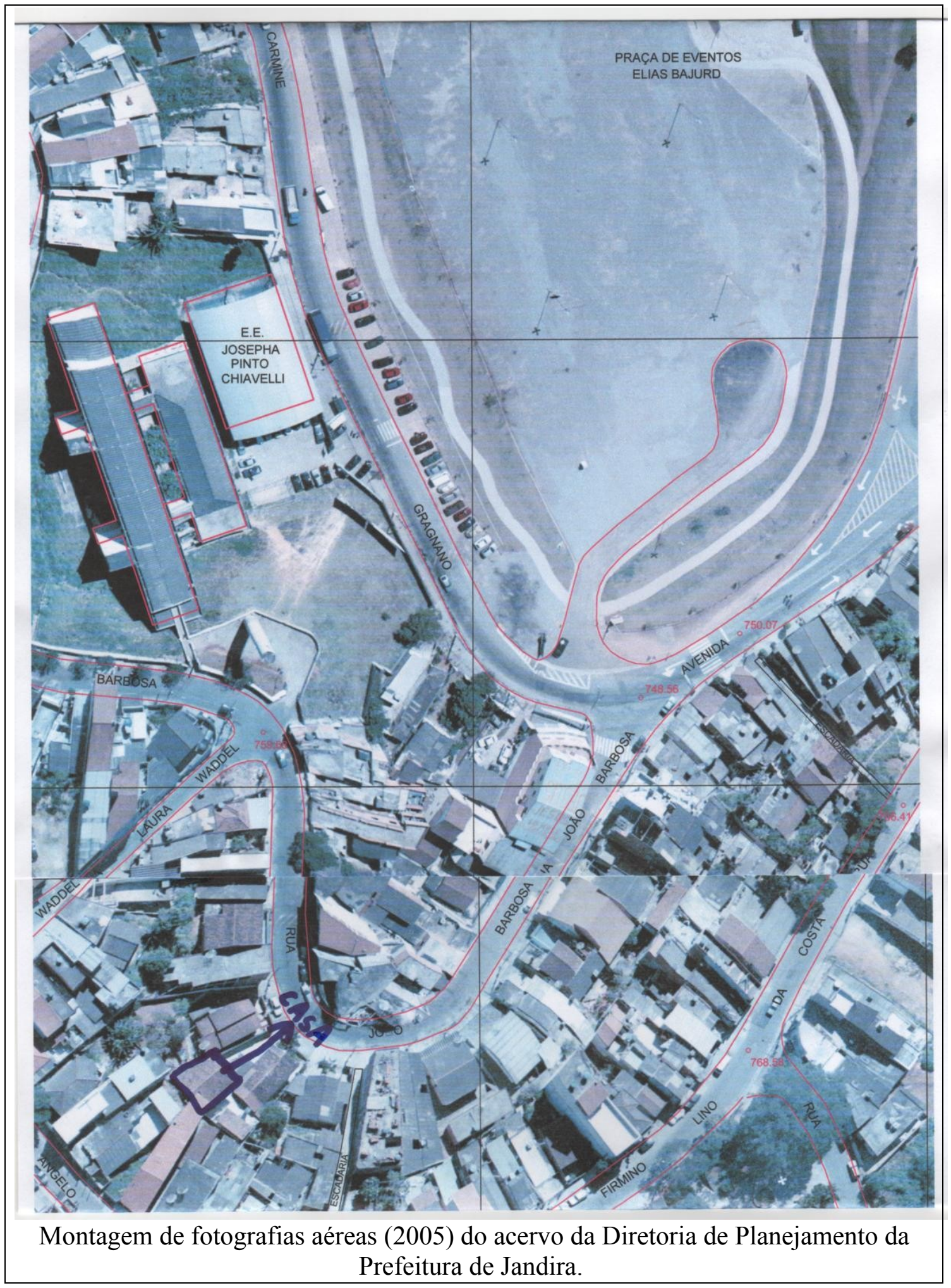


O professor Jonhson era o único que tinha automóvel para fazer todas as "correrias" que esta empreitada exigia, comprar as mercadorias, trazer fogão, bujão de gás, máquina de Churros (da mãe de uma aluna), tambor, gelo, e uma série de coisas. Muitas destas coisas tinham que ser guardadas, pois poderiam ser roubadas - o que por vezes aconteceu.

Do grupo, o Professor Alexandre (este que aqui escreve) é o que mora mais próximo da escola e da festa, portanto, deveria assumir as responsabilidades que antecediam cada dia de festa, bem como, as posteriores. Isto é, ajudar a abrir a barraca e ajudar a fechar. Foram quatro finais de semana terríveis, trabalhávamos sexta, sábado e domingo e a arrecadação bastava somente para reabastecer a barraca.

Por vezes sentávamos de madrugada, enquanto carregávamos as coisas para guardar na escola, e pensávamos em desistir, porém tínhamos assumido um compromisso e concluíamos que faltava pouco, e assim foi, contando os dias para terminarmos o desafio, prestar contas financeiras e finalmente descansar. Boa parte do tempo foi esta a interpretação que tínhamos, mais influenciada por mim, mas 
posso afirmar que nos divertimos muito, principalmente os jovens, para os quais a possibilidade de encontro da festa e da barraca superava em muito o cansaço dos compromissos assumidos.

Não era um desânimo que nos punha para baixo, mas a barraca era uma continuidade do nosso trabalho na escola e ao mesmo tempo não era. Por vezes chegava em casa na madrugada de domingo para a segunda-feira e não conseguia dormir, sabendo que às 7:00 horas teria que estar na sala de aula do $3^{\circ} \mathrm{A}$, uma turma muito agitada, e que na segunda-feira tinha todo um final de semana de festa para por em dia na conversa. Depois de dois finais de semana de festa resolvi este problema. Deixava para de manhã o trabalho de transportar todas as coisas da barraca para a escola, juntava os jovens do $3^{\circ}$ A e em uma ou duas viagens tudo já estava na escola sendo lavado e arrumado.

Existem dificuldades para ver neste tipo de momento a implicação como perspectiva de pesquisa. O que é possível perceber é o estar atolado em uma infinidade de vontades, e ao mesmo tempo sentir-se muito limitado diante da magnitude dos desafios que vamos assumindo frente ao mundo existente. 
Lidamos com esta situação: num ano estou defendendo uma dissertação que apresenta uma interpretação da "Alienação da Festa" e no ano seguinte estou no meio da festa com todas as alienações e mais o mundo do trabalho e os desafios do ensino público neste país, do qual, muitas vezes, somos militantes, além de profissionais.

Por falar em profissionais, as barracas do setor comercial, aparentemente, tiveram o mesmo trabalho, porém com níveis de organização muito melhor e, com certeza, muito mais lucrativo. As barracas custaram $\mathrm{R} \$ 800,00$, num mês de festa cobriram os gastos e tiveram seu lucro, o montante não consegui saber, porém disseram que voltariam no ano seguinte, o que de fato aconteceu.

Já nossa barraca rendeu pouco mais de $R \$ 200,00$, sem contar o que pusemos de nosso bolso e não fomos ressarcidos, pois não teríamos nenhum rendimento, o que seria desestimulante principalmente para os alunos.

O que acontece, desde 2002 na nossa escola, é uma festa junina dentro da escola, voltada à própria comunidade, com participação compulsória dos professores e funcionários e o investimento do resultado financeiro é decidido por votação 
pelos alunos, que em um ano optaram pela compra de máquina para cortar "mato", noutro ano a opção foi ventiladores para as 12 salas de aula, também teve a montagem da rádio da escola.

Nos anos seguintes, cada vez mais, menos entidades comunitárias ou da sociedade civil participaram com barracas na festa junina municipal; a União dos Estudantes de Jandira - UEJ - sempre reivindicou seu espaço. Conseguia com muita resistência dos organizadores, que questionavam, principalmente, os tumultos que acontecem sempre junto à multidão de jovens freqüentadores da barraca da UEJ, reunidos, principalmente, pelo rap, mas também para dividir os vários litros de vinho e as batidas. O que realmente provoca os tumultos são as várias tentativas da polícia militar e da guarda civil municipal de reprimir o consumo de maconha e outras drogas consideradas ilícitas. Não raro há o confronto dos jovens com a polícia.

Além de não conseguirmos resgatar o caráter comunitário da festa junina, ainda caminhamos cada vez mais para a mercantilização, ao ponto de, no ano de 2006, além de ter a área cercada, sob o argumento da necessidade de revista para impedir a entrada de armas, ainda ser cobrado $\mathrm{R} \$ 1,00$ para 
ingresso na festa. A violência mais uma vez é álibi para desmandos. Os ataques do PCC em maio, portanto um mês antes da festa, deram maior respaldo aos defensores do fechamento da área durante a festa, mas é muito difícil ao nível da cidadania sustentar a cobrança. Exceto alguns protestos em reuniões do PT e de alguns vereadores, não houve rejeição à cobrança, que é apresentada como simbólica, por considerar o valor cobrado pequeno. O cercamento da área implicou um custo maior para a festa, que diluído nos 19 dias previstos de festa, este ano, seria simbólico.

Todo espaço da praça de eventos foi cercado e agora é inteirinho cobrado. Este é o maior custo, pois interfere ao nível da cidadania, que raramente é fonte de referência nas nossas periferias. Propiciar o encontro é uma das qualidades do urbano, diminuímos nossa urbanidade, deteriora-se o encontro, quando concordamos com os cerceamentos. Nossa cidade é muito carente de ambientes urbanos, embora esteja melhor em termos de infra-estrutura, mas imersa no cotidiano programado da metrópole, onde aparecemos como perigosos e foco de todos os cuidados no combate à violência urbana. 

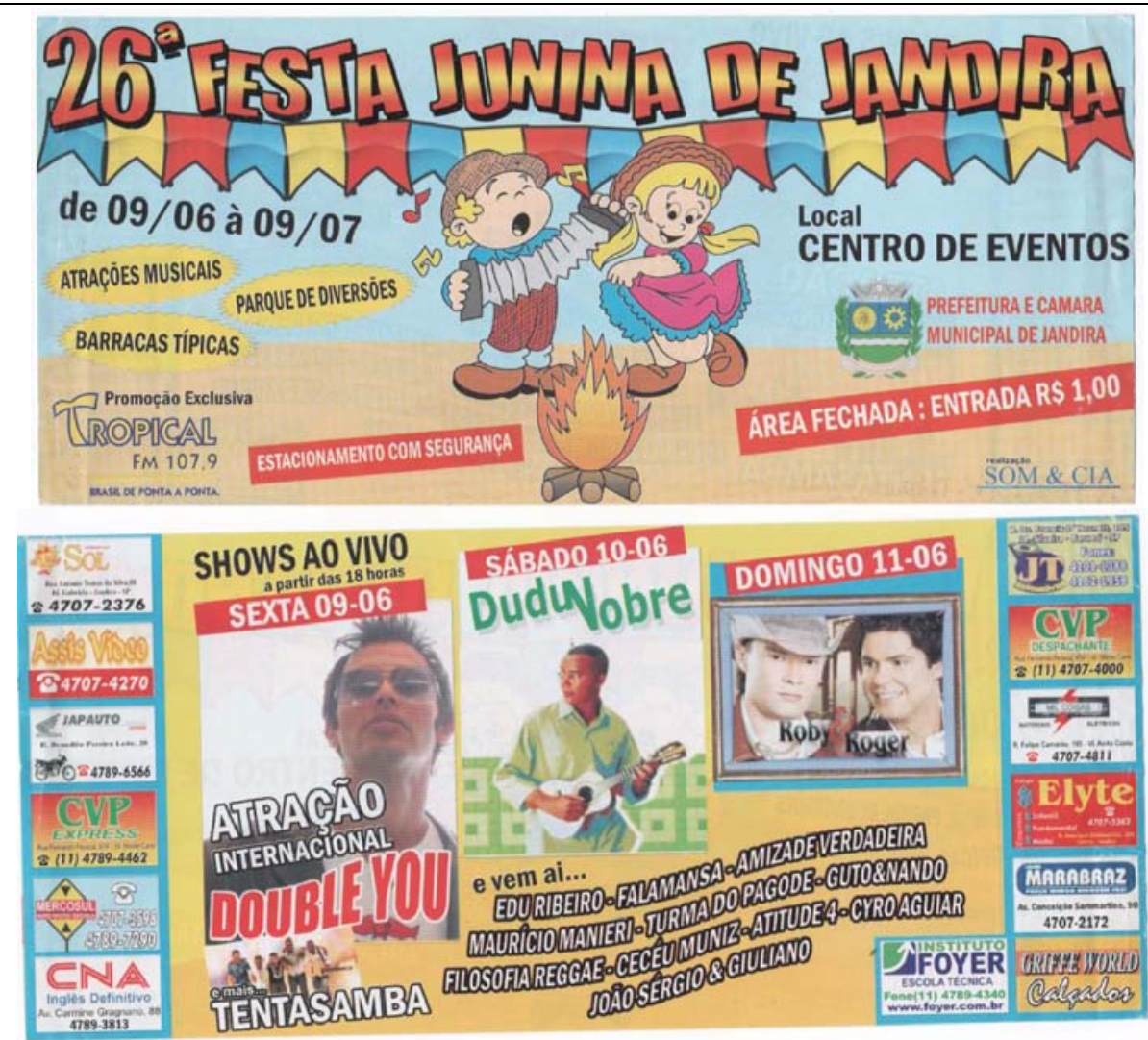

Convites distribuídos na divulgação da Festa com destaque à promoção exclusiva da Rádio Tropical FM, esta exclusividade cobra um real o ingresso na festa.

Os jovens estão ainda mais sujeitados às limitações, que a violência, como álibi, impõe. Além da escola, em nossa cidade, quase não existem alternativas de encontro, mesmo os salões de baile, que seriam alternativa, depois das 23:00 horas são fechados pela chamada "lei seca". Esta lei municipal determina que nenhum estabelecimento, que venda bebida alcoólica, pode funcionar depois das 23:00 horas. 


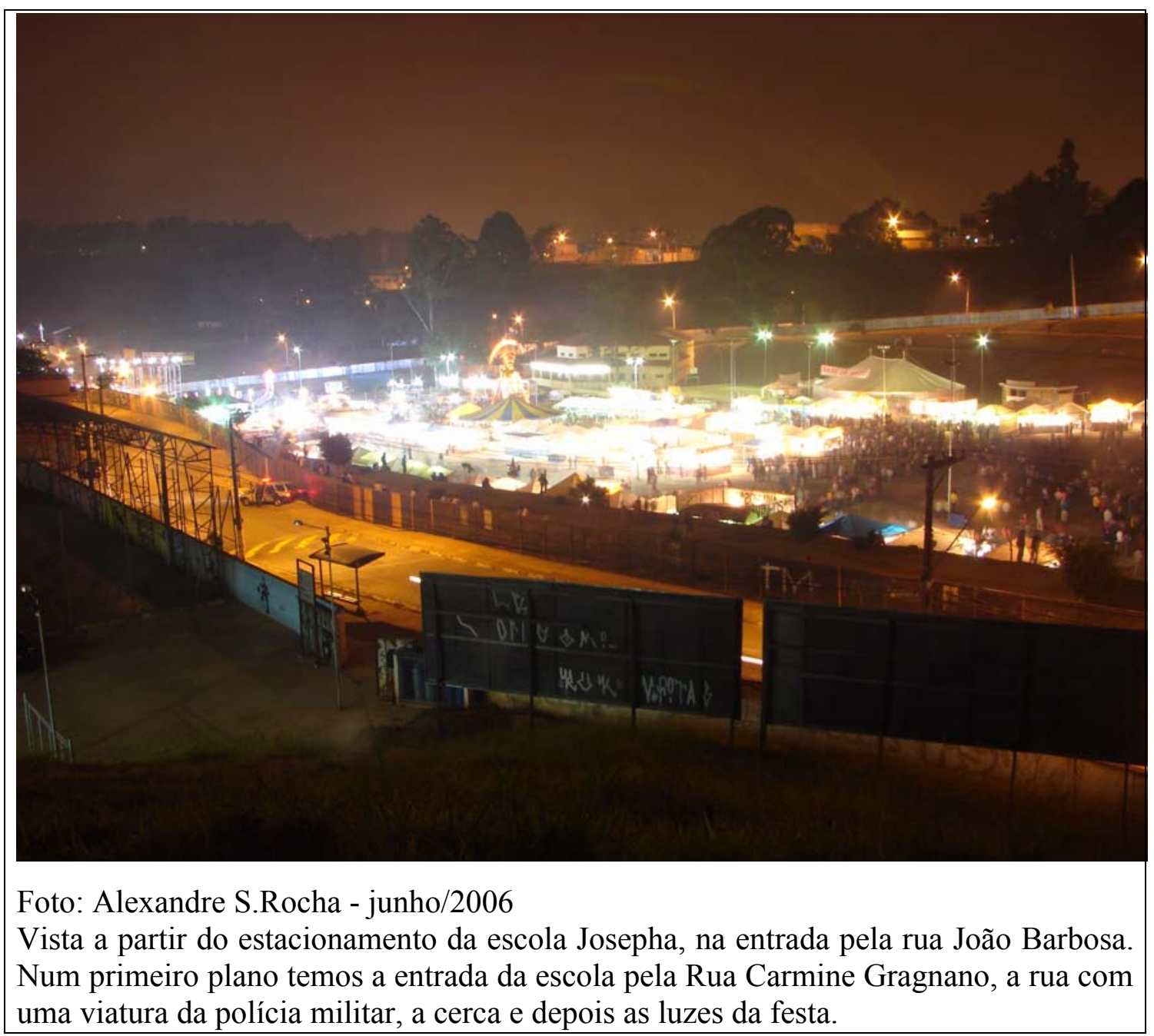

A ansiedade dos alunos pela festa junina é muito facilmente explicada, a grande quantidade de pessoas que se dirigem para a festa, propicia um leque muito maior de encontros e relacionamentos. 


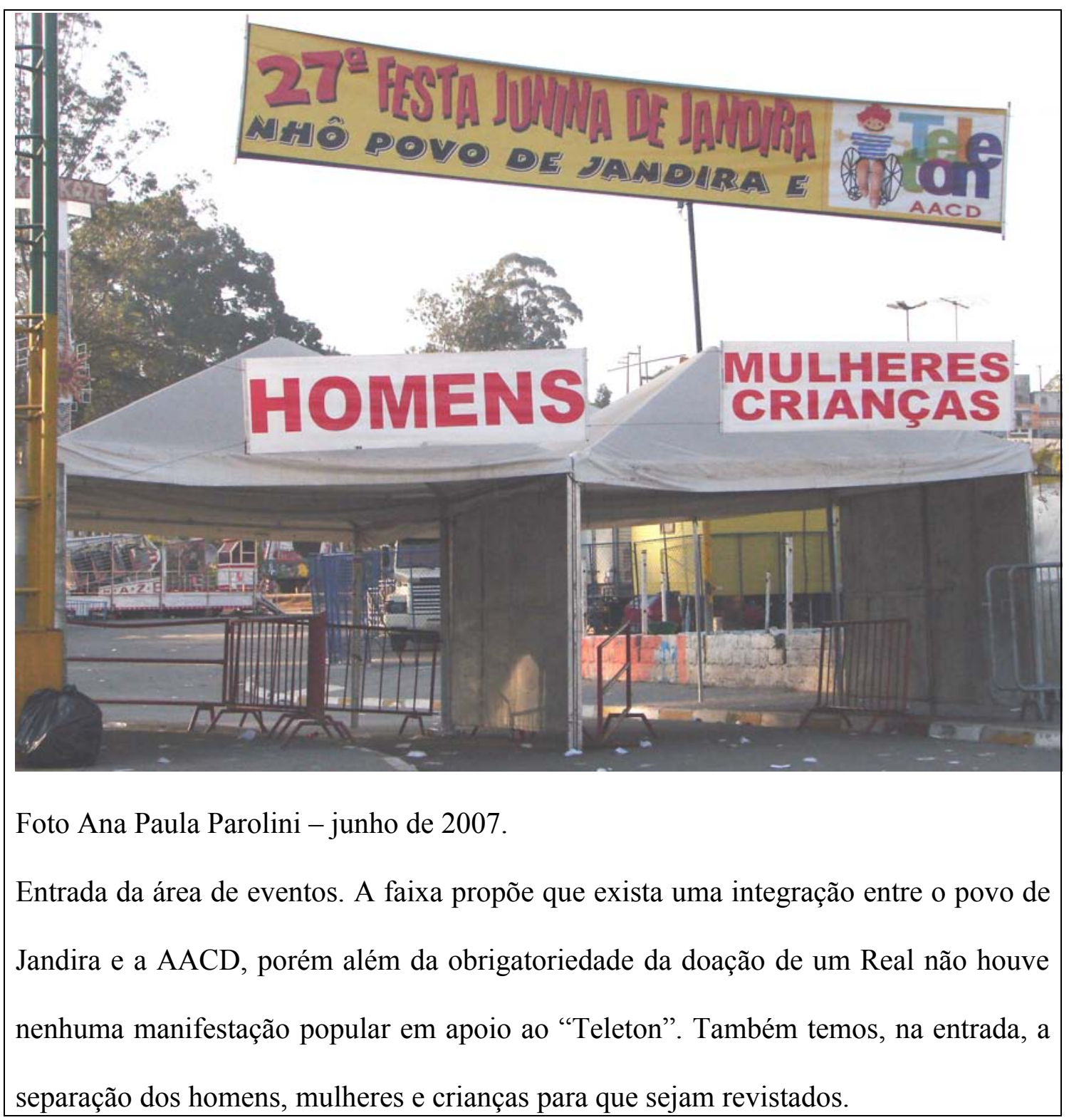

Agora em 2007, além do $R \$ 1,00$ será cobrado mais $R \$$ 1,00 para doação ao "Tele Ton" da AACD. O prefeito na tentativa de colaborar com a entidade especializada no atendimento de crianças portadoras de necessidades especiais, onera em $100 \%$ a participação, em relação ao ano anterior, numa promoção 
assistencial compulsória. Qualquer pessoa que quiser ingressar na festa obrigatoriamente terá que "doar" $\mathrm{R} \$ 1,00$ ao evento "Tele Ton".

Qualquer pessoa, que deseje freqüentar a festa os três dias de final de semana, terá que desembolsar $R \$ 6,00$, em 4 finais de semana serão $R \$ 24,00$. Pode-se sugerir que ninguém é obrigado a ir à festa, e que $R \$ 2,00$ reais para ver um show é barato. Argumentos cômodos para as pessoas que não querem perceber que até 2005, ou há 25 anos, este evento era gratuito, não passava pelo preço (irrisório ou não).

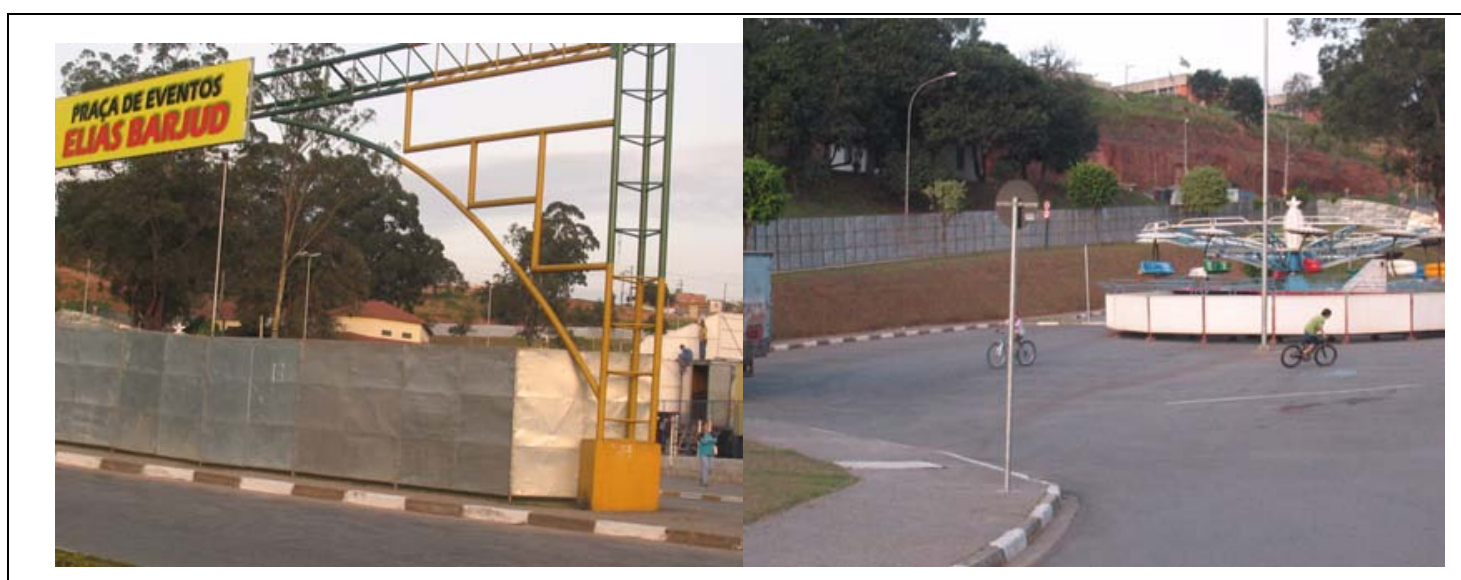

Fotos do fechamento da Praça de Eventos Elias Barjud, nome do pai do atual prefeito (01/06/2007). Vamos observar como será este ano. 


\section{O processo político de produção da pobreza- o caso da moradia}

Se existe um espaço privilegiado de aproveitamento das condições de sobrevivência para a cooptação política da pobreza, este espaço é a favela, talvez mais que a fábrica. E se existe algum privilégio dos periféricos, este também pode ser creditado a sua peculiaridade na deficiência das condições de habitação. A periferia será objeto de todos os cuidados - Estado, igrejas, narcotráfico. Governantes, parlamentares, polícia, padres, pastores, traficantes e outras personalidades do poder esforçamse para aparecer com alguma eficiência perante as populações periféricas.

Não se combate a pobreza, mas visa-se os pobres como objeto de inúmeras estratégias. A favela é uma das formas mais visíveis das desigualdades do processo de produção da pobreza e, portanto, é extremamente atraente para aqueles que procuram por necessitados. Ou melhor, nada melhor para o exercício do poder que aqueles que são seu resultado.

$\mathrm{Na}$ maioria das vezes, os moradores de lugares em situação de risco estão disponíveis para a ação do poder, e são 
inúmeros os discursos atraentes, pois apelam para a situação que aflige a todos que ali residem. A imposição de lógicas muito potentes já está patente na condição de moradia, o próprio espaço é revelador, principalmente nas grandes metrópoles, que são resultados de acúmulos enormes da sociedade burocrática de consumo dirigido. ${ }^{29}$

Para os candidatos a mandatos eleitorais, a situação de pobreza é um campo fértil para cooptação dos votos, suas carências são patentes, enriquecem os discursos facilitando as promessas.

O aparato policial tem justificativa para sua existência através da necessidade de contenção das várias formas de discordar das situações de desigualdades, das quais a miséria é resultado. O principal foco das ações chamadas de segurança pública está nos ambientes de pobreza. A presença do policial nestes ambientes não é por conta da segurança da população ali residente, mas para garantir que dali não saia provocações contra os locais representativos da concentração de renda. As questões de violência urbana subjugam a sociedade inteira, não da mesma maneira e com os mesmos objetivos em todos os

\footnotetext{
${ }^{29}$ Lefebvre, Henri. A Vida Cotidiana no Mundo Moderno. Editora Ática. São Paulo: 1991.
} 
lugares, pois nos bairros de classe média alta, nos condomínios de alto padrão, empresas... precisam da presença de parte da população do locais de concentração de pobreza, e aí os cuidados são com sua entrada, já nos bairros da periferia somos vigiados ao sair.

As igrejas têm necessitados para consolar com promessas de um reino para eles, justificando o sofrimento do dia-a-dia com a eternidade.

Os traficantes, além de uma mão-de-obra abundante, ainda têm clientela e também escudo humano, nos ambientes de pobreza.

Em Jandira temos um bairro chamado Jd. Figueirão que foi objeto de um projeto habitacional a partir de 2001. Teve dois focos principais: solucionar a situação habitacional de 14 famílias que estavam enterradas na lama, resultante de esgotos e águas pluviais, com uma compreensão de participação popular e de que moradia é mais que a construção da casa. Na mesma perspectiva, insere-se um outro grupo, de 106 famílias moradoras em casas de alvenaria, numa ocupação proporcionada por clientelismo eleitoral, que empurrou as pessoas a construírem aos trancos e barrancos alguns cômodos 
e colocar a família dentro, antes que algum fiscal aparecesse. E também temos o entorno desta área composto de loteamentos com algum nível de irregularidade.

O programa "Habitar Brasil" prevê um conjunto de ações, na maioria obras de infra-estrutura e construção de unidades habitacionais, financiadas a partir de recursos do FGTS, que podem ser a fundo perdido ou a título de financiamento. Em 1998 o município de Jandira firmou um convênio com o Governo Federal dentro do escopo deste programa.

Uma parte do programa foi executada, até 2000 , no bairro Dolores Paschoalim (nome da mãe do então prefeito Braz Paschoalim), drenagem e canalização de esgoto, obras enterradas que muitos dizem não render votos, mas quando executada no momento das campanhas eleitorais, além de votos, podem render ajuda na campanha, visto que o que está enterrado somente é medido pelas planilhas de execução físicofinanceira. Do montante que foi previsto para o município ainda estava previsto em 2001, a construção de 20 unidades habitacionais e outras obras na vila Eunice e Dolores Paschoalim. 
A partir de 2001, com uma perspectica democráticopopular, sobrou o desafio de aproveitar a possibilidade de investimentos residuais e ao mesmo tempo construir outros projetos, não necessariamente reprodutores das dependências, mas com a perspectiva de construir outras possibilidades dentro de situações contraditórias e conflituosas.

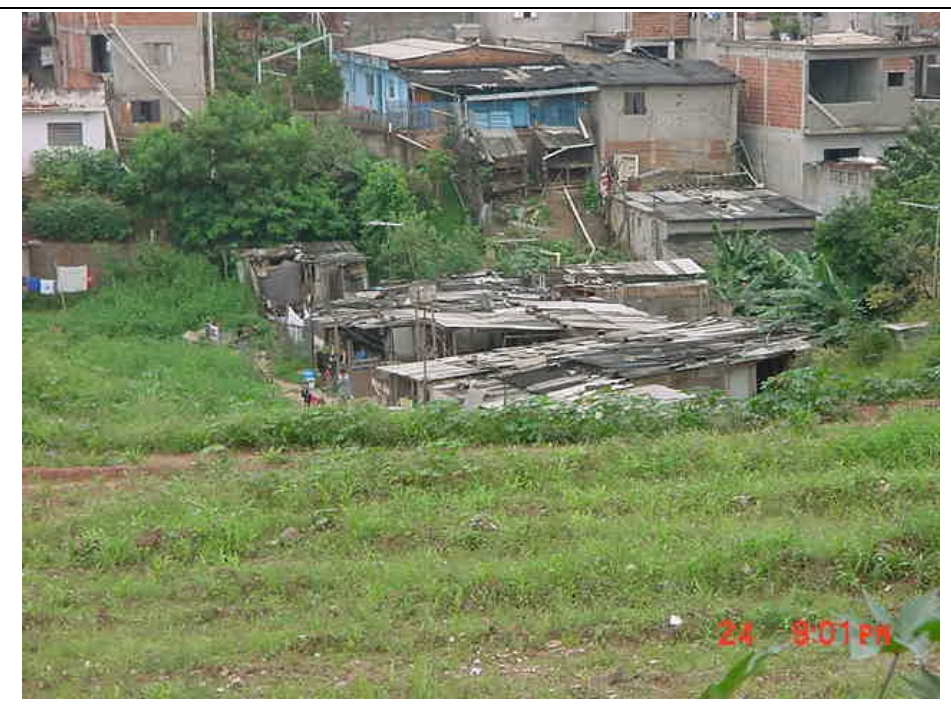

Foto: Alexandre Souza da Rocha 2001

Favela do Bairro Jardim Figueirão próximo ao centro do município de Jandira. Experiência em elaboração de projeto habitacional junto com a comunidade, tanto as residentes nas habitações precárias enterradas na área de inundação da drenagem de águas pluviais e esgotos do bairro a montante, quanto os moradores do entorno da favela que não serão beneficiados com a construção das casas.

Com assessoria de uma ONG (Passo - Assessoria para ações sociais) vinculada a movimentos de moradia, foi desenvolvida uma série de discussões com os moradores do bairro Jardim Figueirão. O bairro é composto por lotes urbanos pertencentes aos loteamentos do Jardim Lindomar e Vila Eunice, 
que fazem fundos para uma área, de aproximadamente 36.000 metros quadrados, adquirida pela prefeitura do município na década de 1970, para a construção da delegacia municipal. Esta área foi parcialmente ocupada na década de 1980, inicialmente por algumas famílias organizadas, que, na época, contaram com o apoio de um vereador, e depois o próprio prefeito terminou por distribuir terrenos com finalidade eleitoral, tornando-se uma ocupação em alvenaria com as residências que se verticalizaram em terrenos de 40, 50 e até 60 metros quadrados. Na década de 1990, um grupo de índios da Bahia construiu 14 barracos, numa área de inundação e posteriormente venderam. Restou sem ocupação aproximadamente 6.000 metros quadrados, onde funcionava o "campo do Figueirão".

Para as discussões eram convidados todos os moradores do bairro (as 14 famílias, da ocupação promovida a partir dos interesses eleitorais, bem como os moradores que adquiriram lotes com a imobiliária), embora, a perspectiva fosse a urgência de resolver o problema das 14 famílias enterradas na lama. 


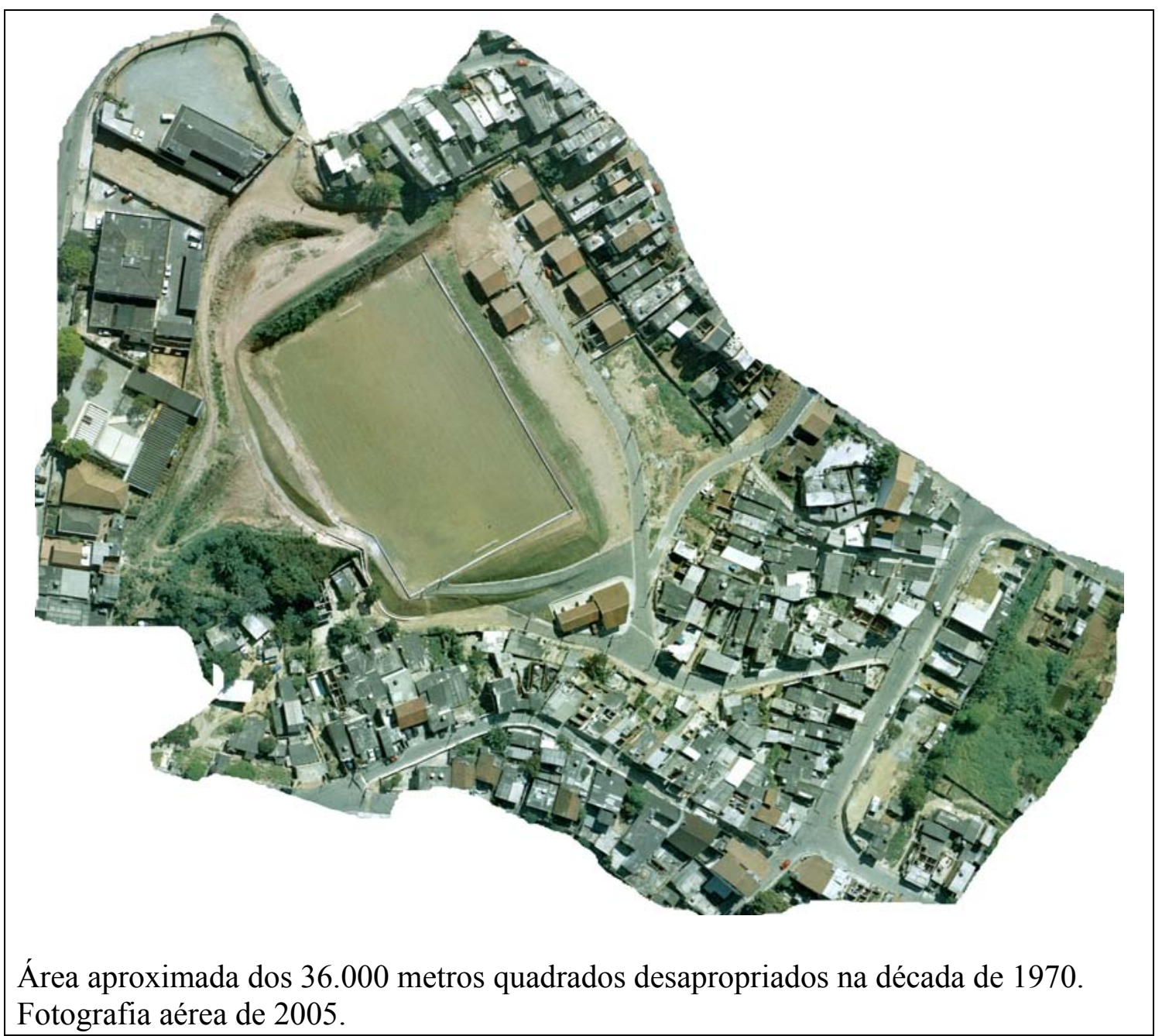

Tinha-se como premissa que era necessário envolver no debate, inclusive, as pessoas que haviam comprado os terrenos "formais" para construir suas casas. A pretensão era mais que construir casas para os que estavam em pior situação. Não somente a casa, mas a criação de um ambiente de sociabilidade, além do atendimento aos necessitados. Os necessitados tinham que ser vistos como membro da comunidade ${ }^{30}$ e não como
${ }^{30}$ COMUNIDADE, terminologia imprecisa, os moradores mais antigos se definem assim, não só no Jd.
Figueirão, é recorrente em vários outros locais, não só em Jandira, utilizarem o termo comunidade para 
invasor. A comunidade, também, não poderia ser vista como preterida em função dos necessitados, pois também tinham suas demandas.

Nas reuniões, estas e outras contradições e/ou conflitos apareceram, e a assessoria veio para contribuir na construção deste projeto social, ao mesmo tempo, ao nível da necessidade elementar e o da construção social da comunidade. Comunidade, que considerando todos os envolvidos, não existia, e ainda hoje é um vir a ser.

A pretensão era produzir uma nova forma de atuação do poder público, junto com a população, solucionar problemas de infra-estrutura e de dignidade de pessoas, que foram deixadas à margem dos investimentos e da democracia. Algumas ações foram encaminhadas, independentes das discussões, como abastecimento regular de água, captação do esgoto, rede de distribuição de energia elétrica, iluminação pública e pavimentação das ruas e vielas, pois além de ser patente a necessidade, tínhamos uma pesquisa com os moradores na qual mais de $70 \%$ das famílias indicavam estes como problemas. 


\begin{tabular}{|l|r|r|}
\hline problemas detectados pela população & Freq. & Freq. \% \\
\hline falta de escola & 1 & 0,6 \\
\hline serviço de transporte & 1 & 0,6 \\
\hline barracos & 1 & 0,6 \\
\hline calçamento & 2 & 1,2 \\
\hline falta de creche & 2 & 1,2 \\
\hline limpeza & 2 & 1,2 \\
\hline organização da comunidade & 2 & 1,2 \\
\hline falta de telefones públicos & 2 & 1,2 \\
\hline respeito entre moradores & 2 & 1,2 \\
\hline lombada & 2 & 1,2 \\
\hline saúde & 3 & 1,8 \\
\hline lixão & 3 & 1,8 \\
\hline regularização fundiária & 7 & 4,2 \\
\hline segurança/policiamento & 7 & 4,2 \\
\hline nenhum & 7 & 4,2 \\
\hline iluminação & 12 & 7,2 \\
\hline regularização da energia elétrica & 21 & 12,7 \\
\hline asfalto & 23 & 13,9 \\
\hline saneamento & 23 & 13,9 \\
\hline abastecimento d'água & 43 & 25,9 \\
\hline & 166 & 100 \\
\hline
\end{tabular}

Secretaria da Habitação, Desenvolvimento Urbano e Ambiental da Prefeitura do Município de Jandira. 2002

Entre 2001 e 2002 foram realizadas algumas pesquisas com a população da ocupação do Jd. Figueirão (14 famílias dos barracos e as famílias da ocupação em alvenaria). Além dos problemas detectados pela população, foi possível quantificar os indicadores de pobreza e algumas dificuldades de organização. 


\begin{tabular}{|l|r|r|}
\hline aquisição da moradia & Freq. & Freq. \% \\
\hline ocupada & 78 & 73,58491 \\
\hline alugada & 7 & 6,603774 \\
\hline cedida & 8 & 7,54717 \\
\hline própria* & 13 & 12,26415 \\
\hline \multirow{2}{*}{${ }^{*}$} & 106 & 100 \\
\cline { 2 - 3 }
\end{tabular}

\begin{tabular}{|l|r|r|}
\hline Participação comunitária & Freq. & Freq. \% \\
\hline participa & 17 & 16,03774 \\
\hline ñ participa & 89 & 83,96226 \\
\hline
\end{tabular}

\begin{tabular}{|l|r|r|}
\hline Sobre a part. e org. comunitária & Freq. & Freq. \% \\
\hline acha importante & 73 & 68,86792 \\
\hline ñ acha importante & 3 & 2,830189 \\
\hline ñ sabe & 30 & 28,30189 \\
\hline
\end{tabular}

Secretaria da Habitação, Desenvolvimento Urbano e Ambiental da Prefeitura do Município de Jandira. 2002

\begin{tabular}{|r|r|r|r|}
\hline \multicolumn{5}{|c|}{ Tabulação da composição familiar } \\
\hline Xi (indivíduos/U.H) & Fi (Freq.) & XiFi & Freq. \% \\
\hline 1 & 5 & 5 & 4,72 \\
\hline 2 & 10 & 20 & 9,43 \\
\hline 3 & 33 & 99 & 31,13 \\
\hline 4 & 27 & 108 & 25,47 \\
\hline 5 & 9 & 45 & 8,49 \\
\hline 5 & 9 & 54 & 8,49 \\
\hline 6 & 10 & 70 & 9,43 \\
\hline 7 & 2 & 16 & 1,89 \\
\hline 8 & 1 & 9 & 0,94 \\
\hline 9 & 106 & 426 & 100 \\
\hline
\end{tabular}

média $=4,02$ indivíduos por família

$56,6 \%$ das famílias é constituída de 3 a 4 indivíduos

$$
\text { População }=426 \text { indivíduos }
$$

Secretaria da Habitação, Desenvolvimento Urbano e Ambiental da Prefeitura do Município de Jandira. 2002 


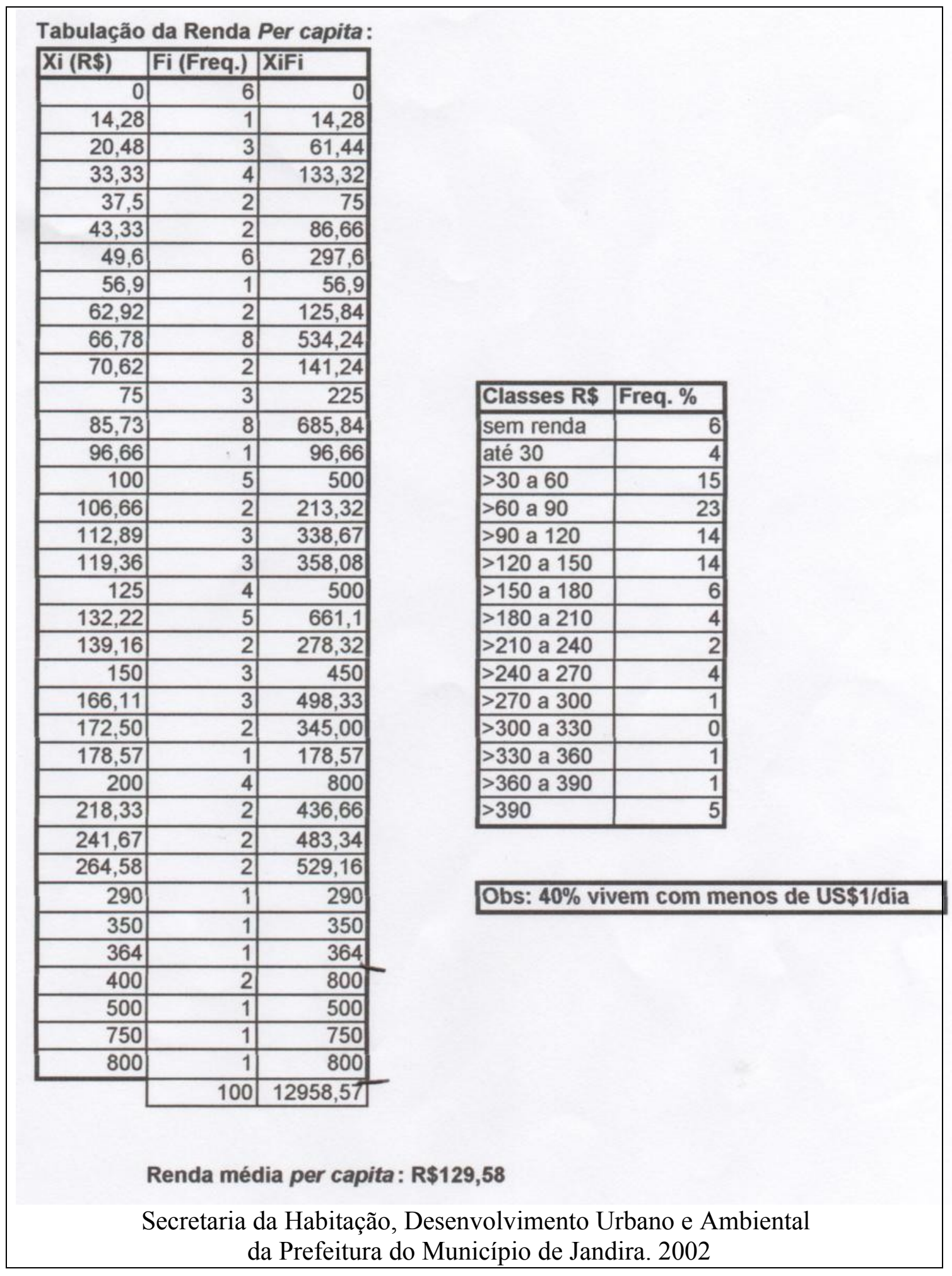


Caberia às reuniões fazer emergir a discussão da organização comunitária, o projeto para o bairro e a busca de soluções para os problemas que surgissem. As propostas elaboradas pela equipe da prefeitura seguiram 0 que se apresentou como demanda, e foram levadas para as discussões e nestas foram sendo aperfeiçoadas.

A construção das 14 casas geminadas foi financiada pelo programa "Habitar Brasil" (Governo Federal), a terraplanagem e execução das obras de implantação do campo, o material para a construção dos vestiários e do centro comunitário seria a contrapartida obrigatória da prefeitura dentro do programa. A creche e o centro de geração de renda necessitavam de dotação orçamentária e ficaram para depois.

A construção do centro comunitário e vestiário possuía dotação apenas para material, a mão-de-obra não estava contemplada no orçamento, o mutirão entre moradores e alguns funcionários da prefeitura foi a solução apresentada e aprovada. 


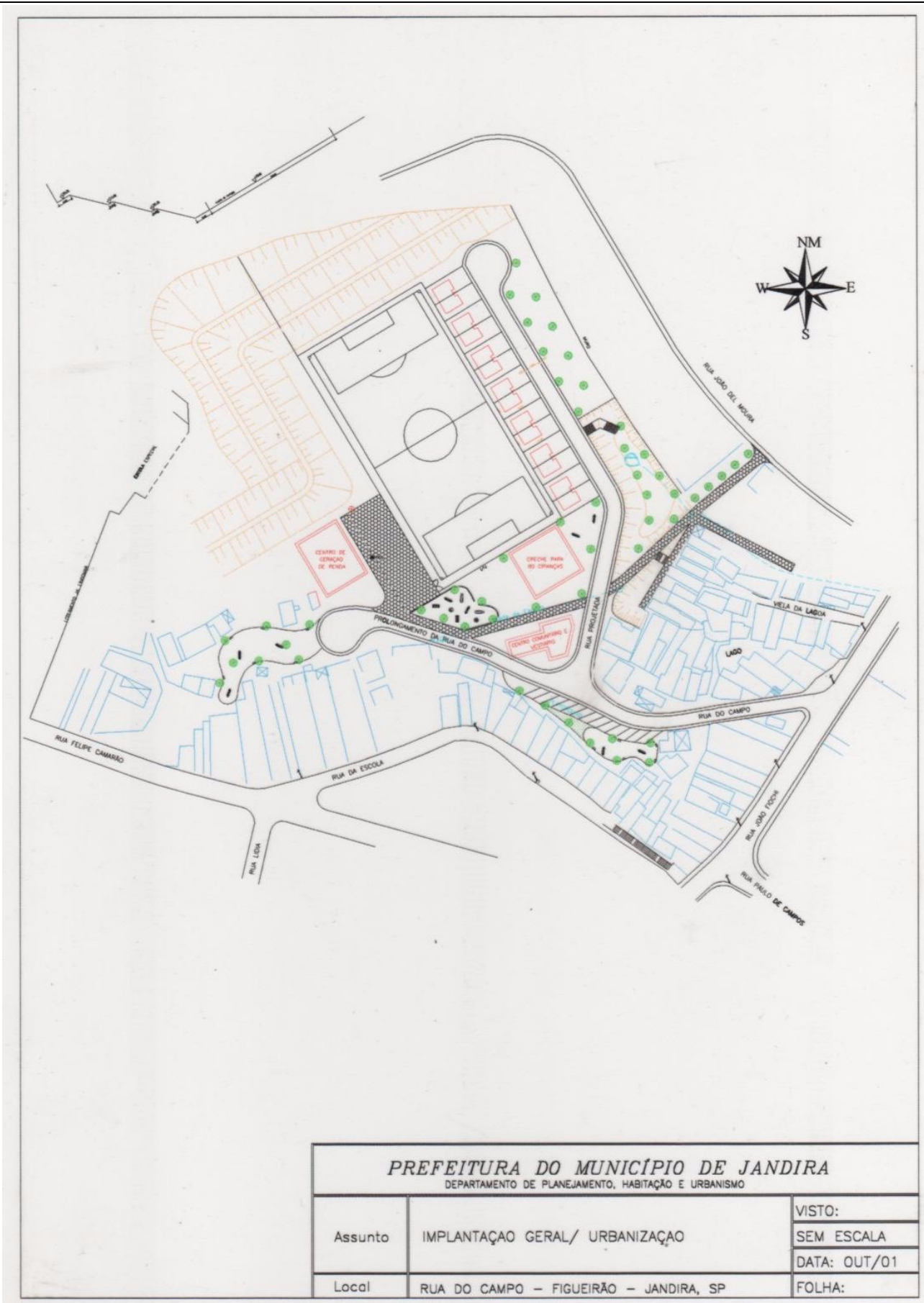

Uma das propostas apresentadas em transparência nas reuniões, além do campo, temos em azul as construções existentes e em vermelho as construções projetadas. (Secretaria da Habitação, Desenvolvimento Urbano e Ambiental da Prefeitura do Município de Jandira. 2002). 


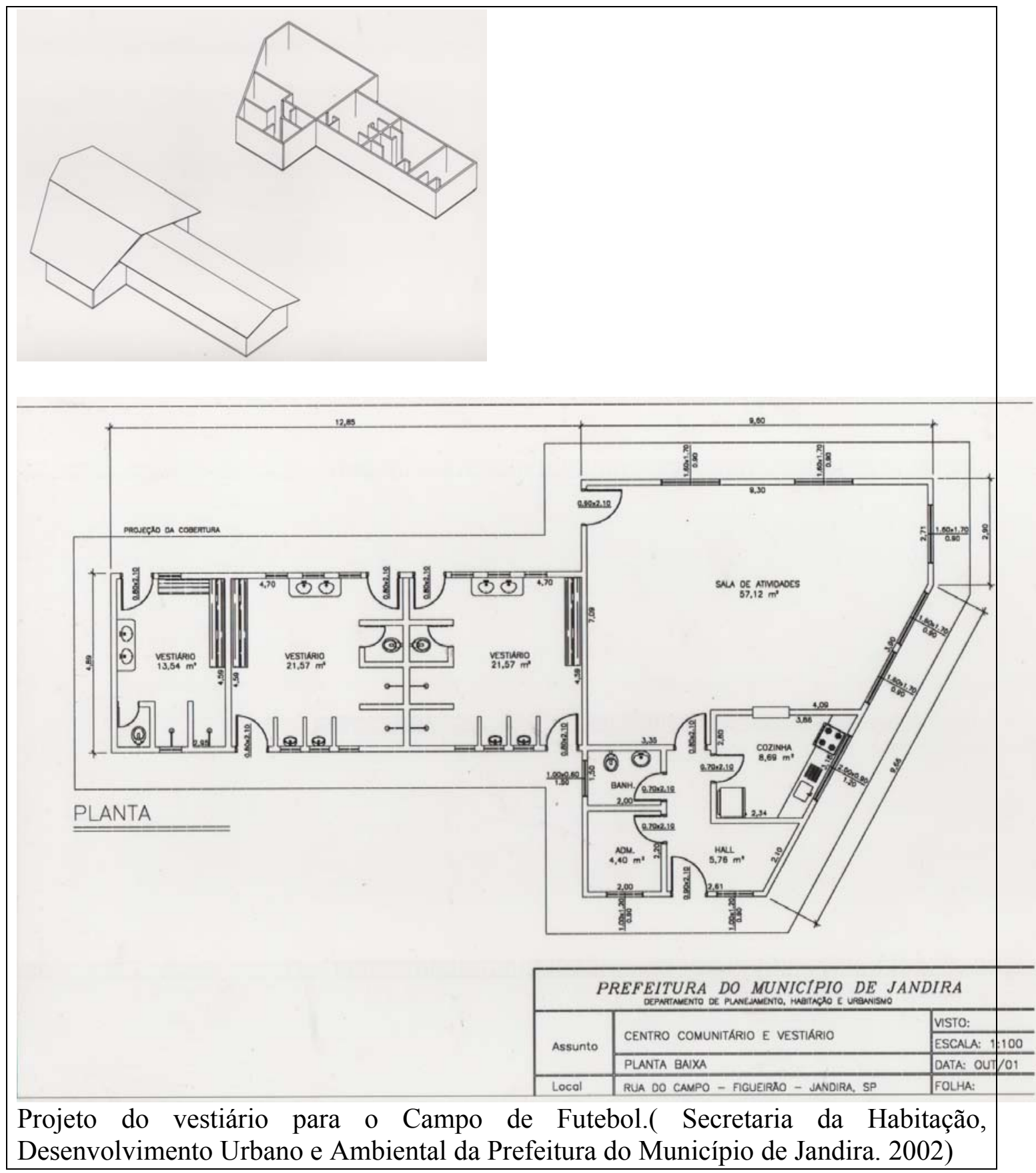



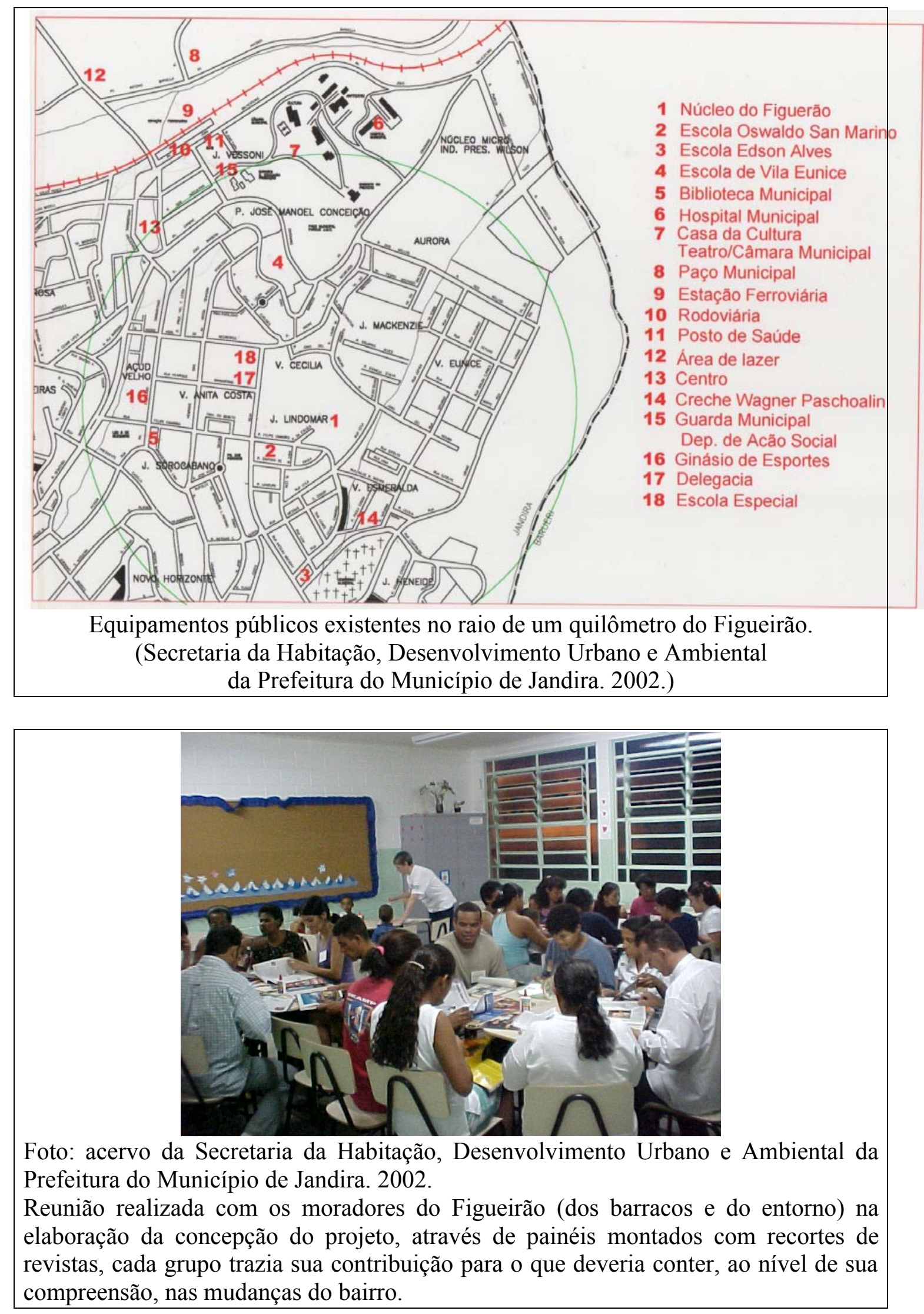

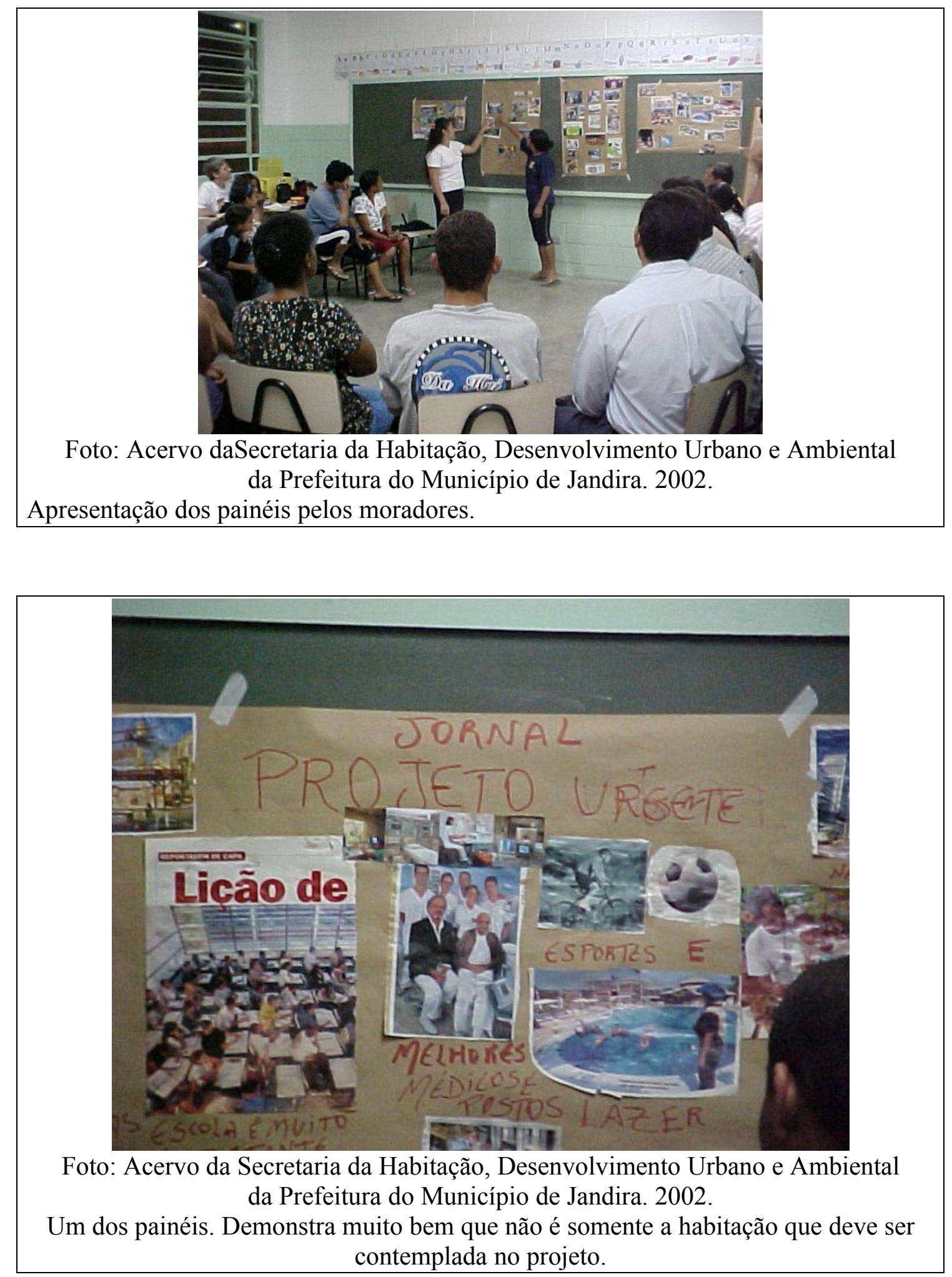


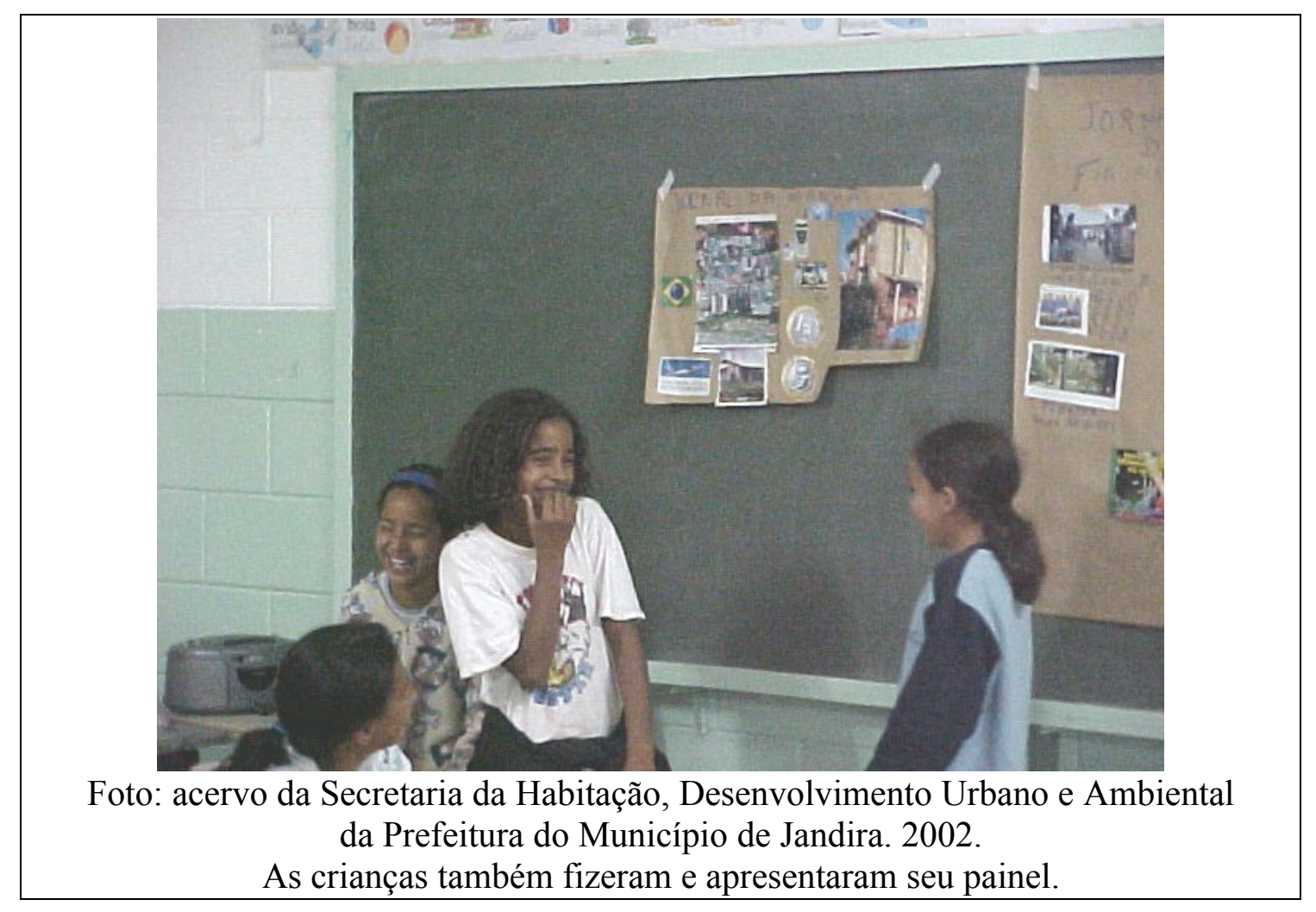

A menina tímida da foto, Tamires, morava num dos barracos que foram demolidos, em 2006 era aluna na $2^{a}$ série do ensino médio, e teve que apresentar um painel em seminário sobre os conteúdos críticos da cidade, parte do programa de geografia para o terceiro bimestre da Escola Josepha Pinto Chiavelli, inicialmente a indagação era se ela lembraria da experiência que passou em 2001. Aparentemente não lembrou, seu grupo apresentou um trabalho sobre a saúde.

A menina Tamires, agora, é uma jovem mãe. Engravidou no segundo semestre de 2006, junto com o namorado, construiu 
um barraco na favela do lixão de Carapicuíba. A trajetória dos pais, aparentemente vai ser seguida pelo jovem casal. Os projetos sociais aplicados no bairro e especialmente para as 14 famílias, as orientações fornecidas na escola, inclusive o desenvolvimento e apresentação de um trabalho sobre saúde, aparentemente, não desenvolveu na Tamires uma consciência crítica, ao nível prático, sobre a situação em que está inserida. Será só com ela? Qual o potencial de intervenção ao nível prático (no jeito de levar a vida), da vida vivida dos projetos sociais e/ou educacionais?

Uma tentativa de diluir o poder nos ambientes de maior vulnerabilidade para as pessoas morarem, como na favela do Figueirão, é fazer junto com os moradores, não, necessariamente, as casas, pois nesse caso as casas foram construídas por uma empresa contratada pela prefeitura dentro do programa "Habitar Brasil", mas o projeto, pois o problema de moradia é muito maior que os números sobre o déficit habitacional, em muitos casos, não é a falta de habitação e sim as condições de moradia - mobilidade urbana, infra-estrutura, possibilidades de encontro, lazer, ócio, desemprego, renda. 


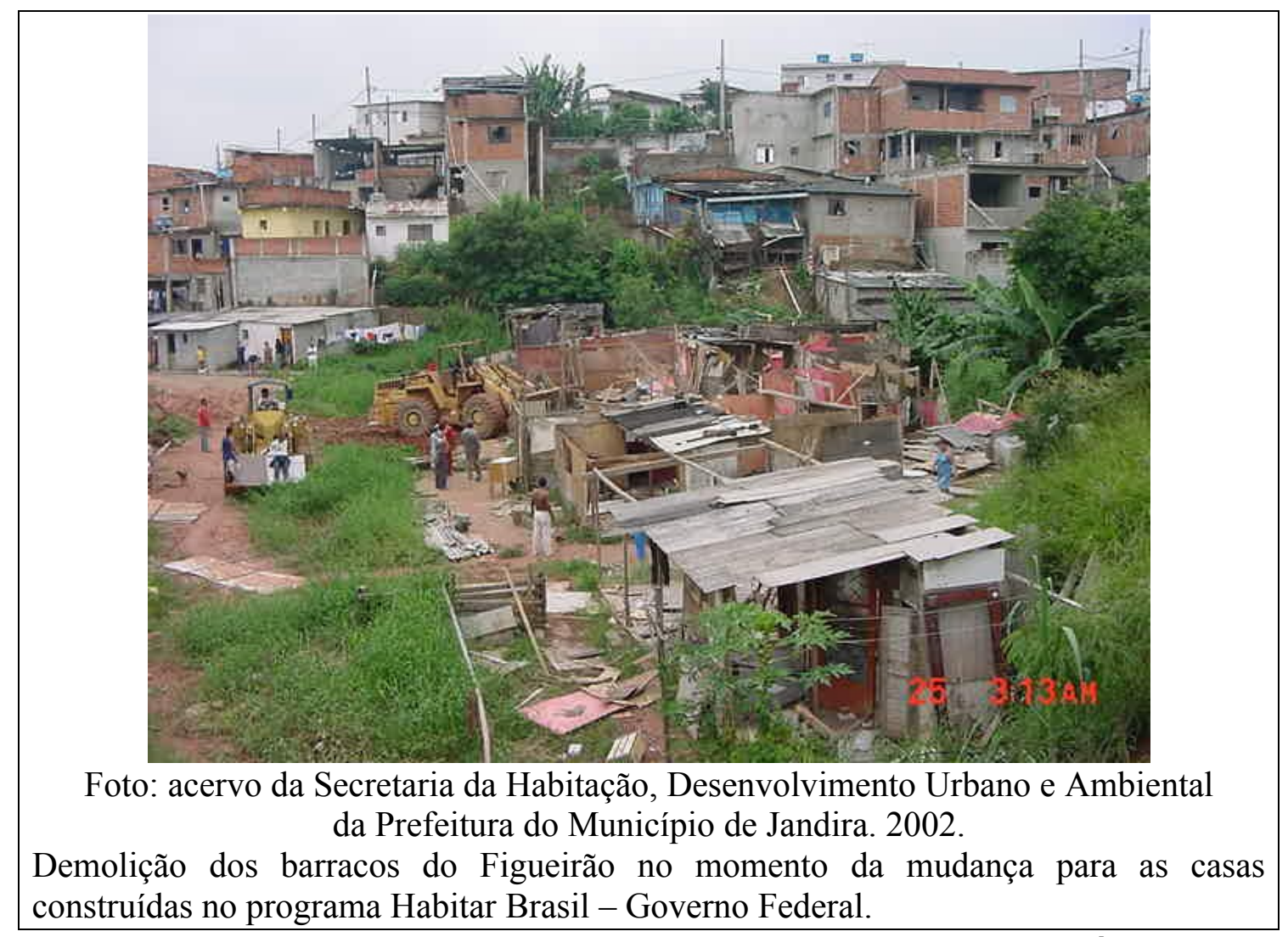

A demolição dos barracos foi executada com máquinas e

funcionários da prefeitura junto com os moradores, que ao desfazerem os barracos aproveitavam o que desse, o restante foi retirado do local. Junto às 14 casas foi construído um NIC Núcleo de Integração Cidadã - da Diretoria de Cidadania e Ação Social e um Campo de Futebol de tamanho oficial, mais de 5.000 metros quadrados.

A mudança foi feita com ligação clandestina de energia elétrica e com a água sem hidrômetro da Sabesp, pois as concessionárias de serviços públicos utilizam as necessidades da população como forma de pressão sobre as administrações 
municipais. Em relação à Eletropaulo existe uma pendência judicial entre a Prefeitura do Município de Jandira e a Empresa, e por conta disso esta última se recusava a executar a extensão da rede até as casas, a pouco mais de duzentos metros. Os moradores providenciaram os "gatos". A prefeitura oficialmente não tem nenhum envolvimento. O que não poderia continuar era as pessoas enterradas na lama, com suas casas prontas, porém por conta de pendências jurídicas e pressões políticas as concessionárias de serviços públicos recusam-se cumprir sua função.

A solução foi tão simples, em face à ocupação das casas e à perda de arrecadação das tarifas, foram executadas as obras necessárias para o abastecimento regular e tarifado dos serviços públicos de água e energia. 


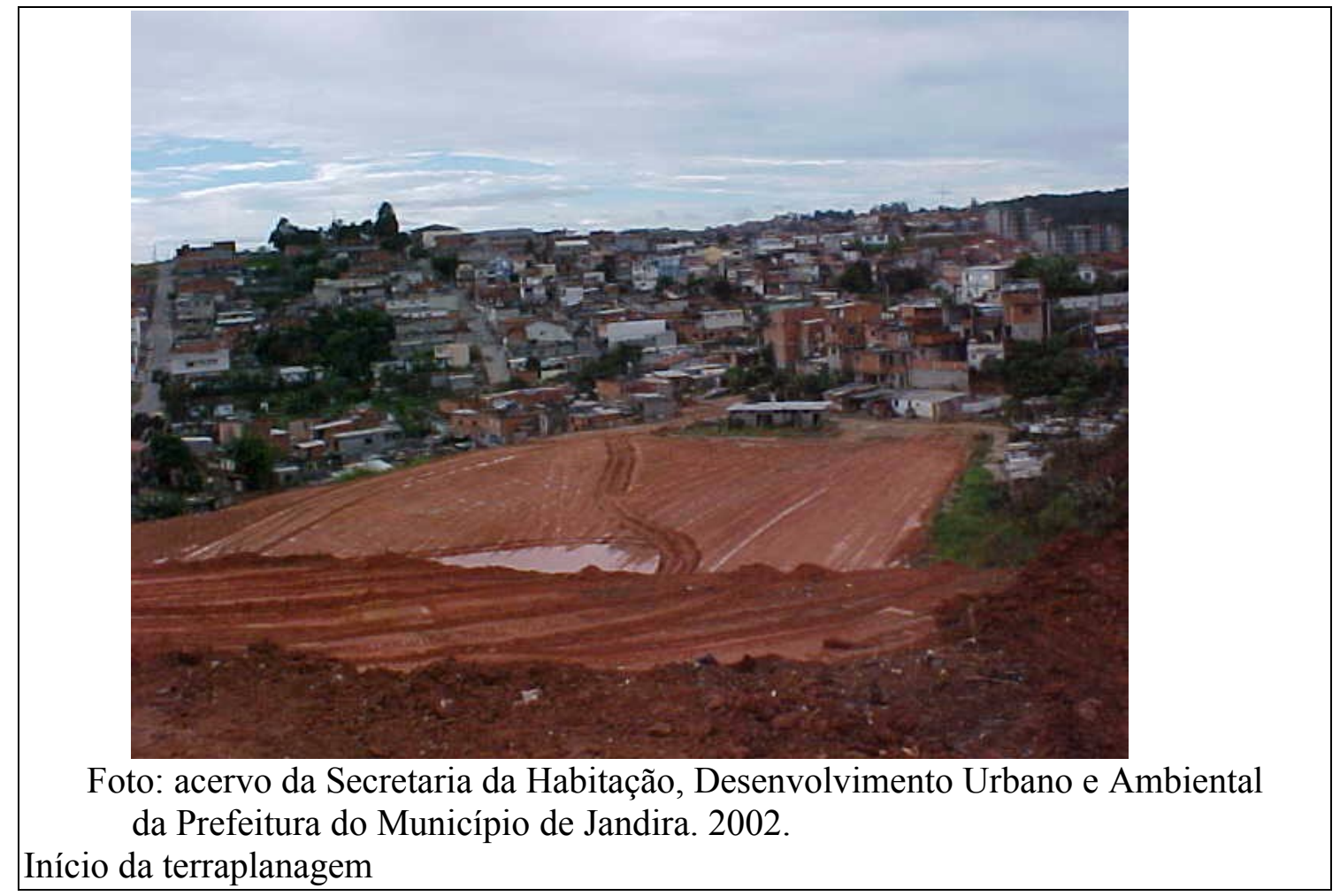




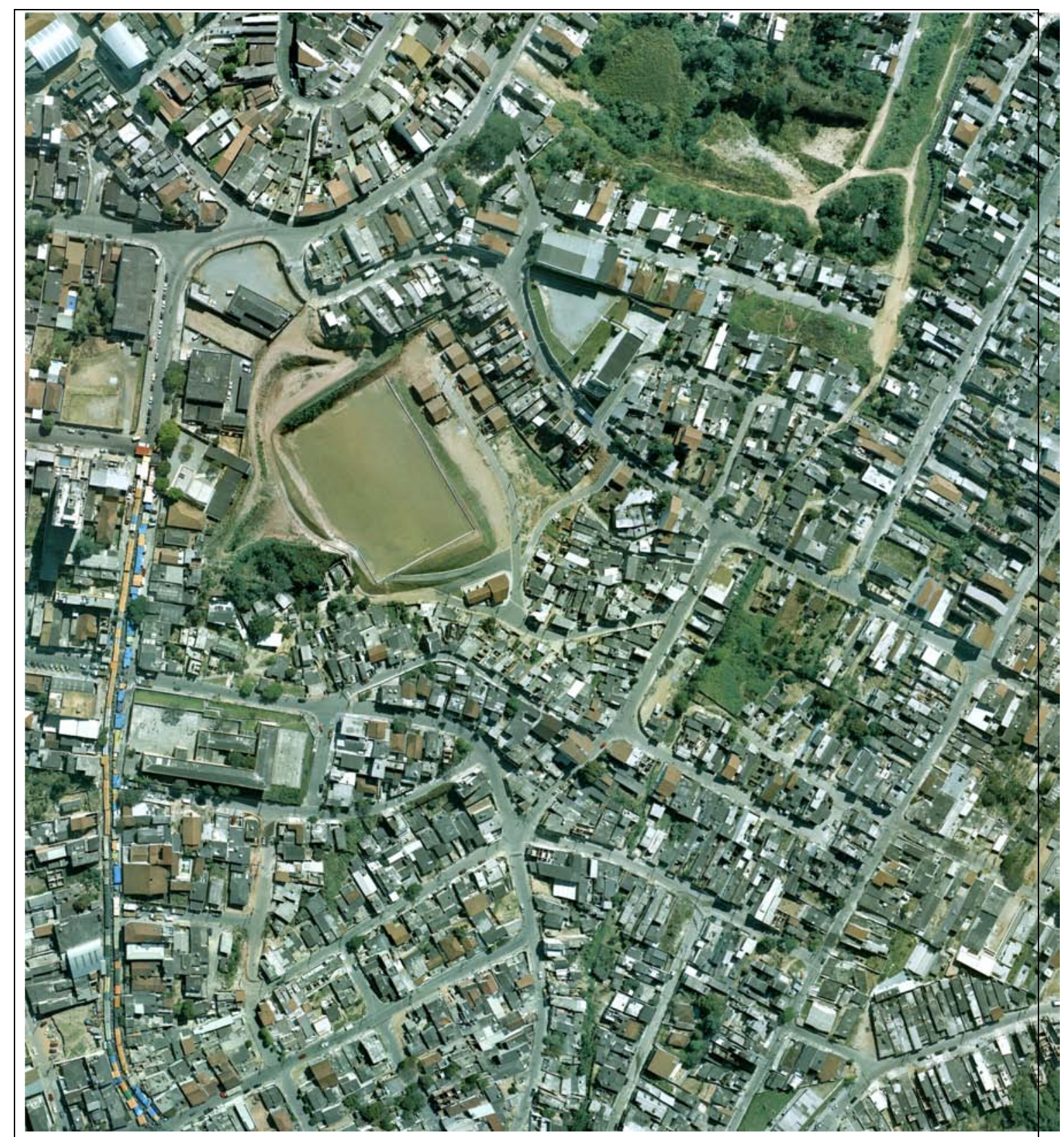

Fotografia aérea de 2005 (sem escala) onde temos o Campo do Figueirão e seu entorno.

A fotografia aérea de 2005 permite perceber o campo do Figueirão, onde ao lado vê-se as 14 casas geminadas. Embora o padrão de autoconstrução explica quase a totalidade das edificações, é possível perceber as construções em lotes formais 
e as ocupações irregulares, por exemplo junto ao campo do Figueirão, ocupação que foi resultado do clientelismo político, onde é possível verificar uma organização aleatória dos lotes.

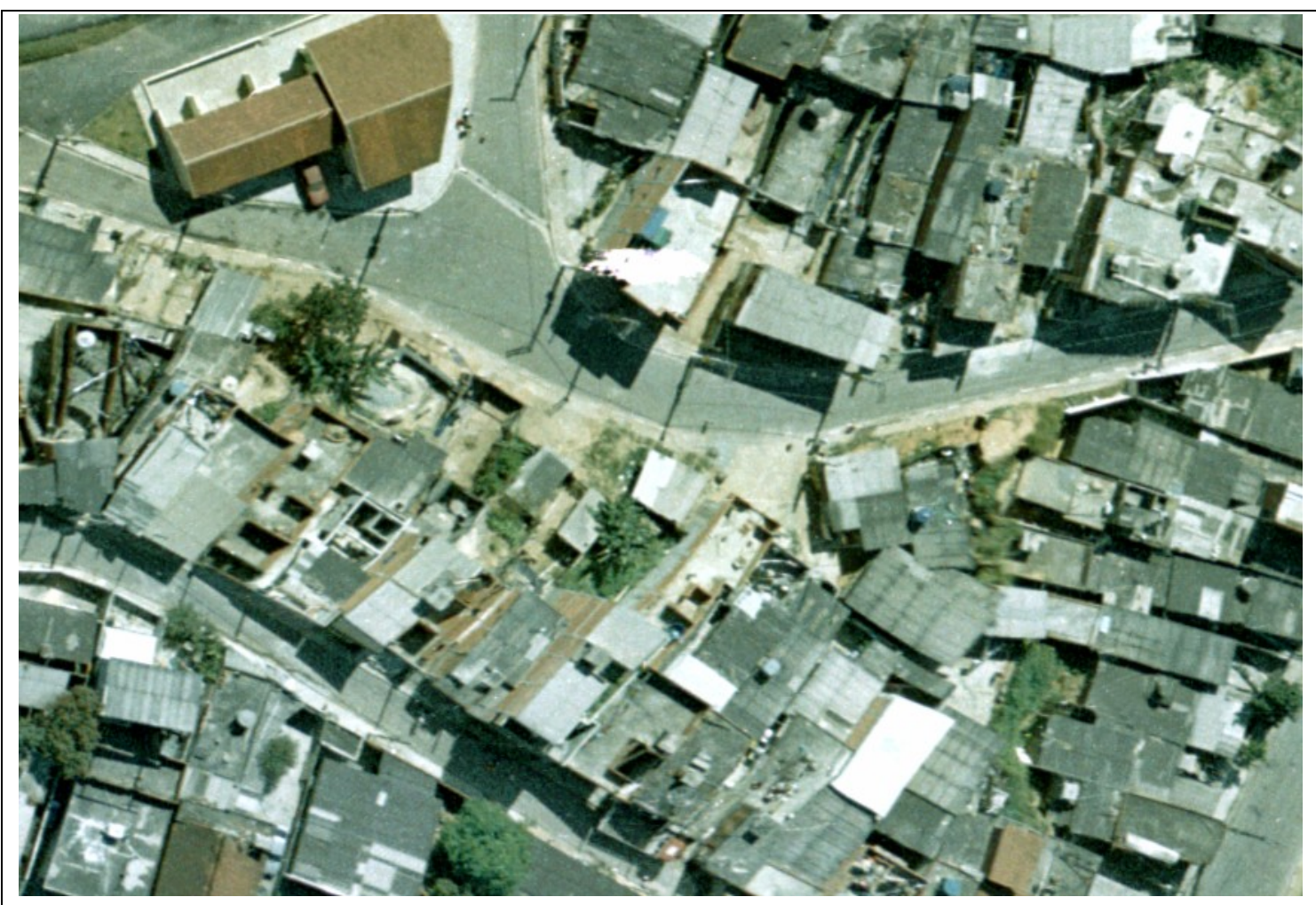

Trecho de fotografia aérea (2005) sem escala 


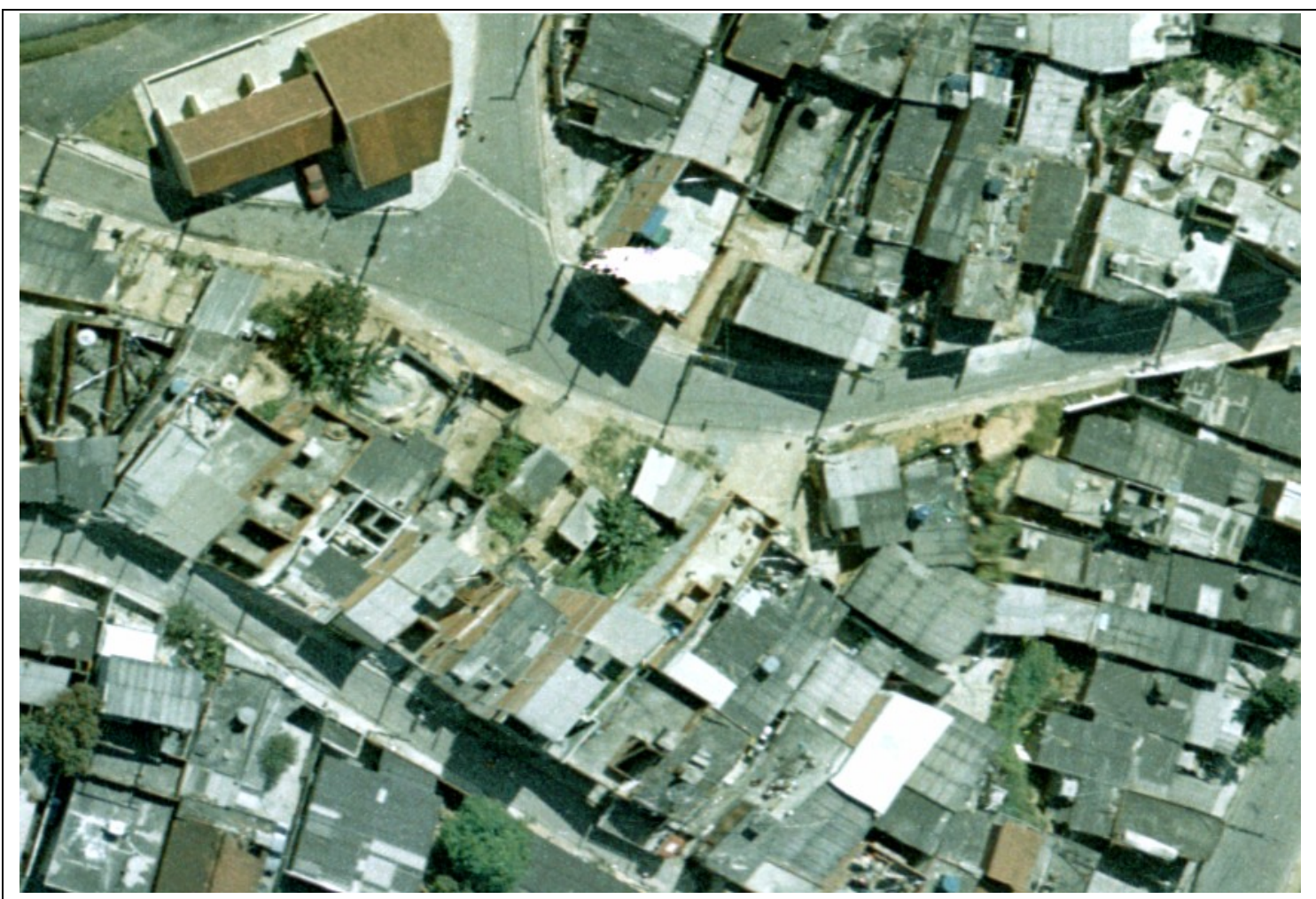

Detalhe contendo o edifício do Núcleo de Integração Cidadã - NIC junto à ocupação do Jardim Figueirão. (foto 2005)

No detalhe além do edifício do Núcleo de Integração Cidadã - NIC do Figueirão temos as construções oriundas das doações com finalidade eleitoral. É interessante observar a disposição dos telhados que apresentam uma configuração aleatória, muito diferente dos locais que tiveram lotes demarcados. Aqui não é só aparência, muitas construções se deram, literalmente, da noite para o dia e foram acontecendo do jeito que dava.

O centro comunitário e o vestiário que estavam previstos de ser construídos em mutirão, foram os últimos, a compra dos materiais fora executada dentro do prazo previsto, porém não 
conseguíamos fazer com que o mutirão andasse, e para concluir como contrapartida prevista dentro do escopo do programa Habitar Brasil foi necessário utilizar funcionários do Departamento de Obras.

Atualmente quanto ao que seria o Centro Comunitário e a sede do Núcleo de Integração Cidadã - NIC - do Jd. Figueirão, da Secretaria Municipal de Cidadania e Ação Social, existe o espaço para a comunidade desenvolver atividades no Núcleo, a dificuldade é a organização da comunidade. Nas primeiras reuniões de 2001, a freqüência era bastante significativa, é possível que fosse mais por apreensão em relação aos possíveis acontecimentos e algumas demandas particulares que pela consciência.

Os interessados nas partidas de futebol tinham a preocupação da manutenção do campo no projeto. Outra preocupação, sempre presente, era em relação ao saneamento, e junto com esta havia um receio muito grande de perder a moradia, dado a irregularidade da ocupação. A participação nas atividades diminuía com os avanços nas obras e andamentos dos projetos - numeração das casas, cadastramento das famílias, alvará de funcionamento dos estabelecimentos 
comerciais... Através do programa Pró-Sanear do Governo Federal foi implantada rede de água, esgoto e drenagem das águas pluviais. Com verbas municipais, executou-se a pavimentação das vias e o calçamento das vielas.

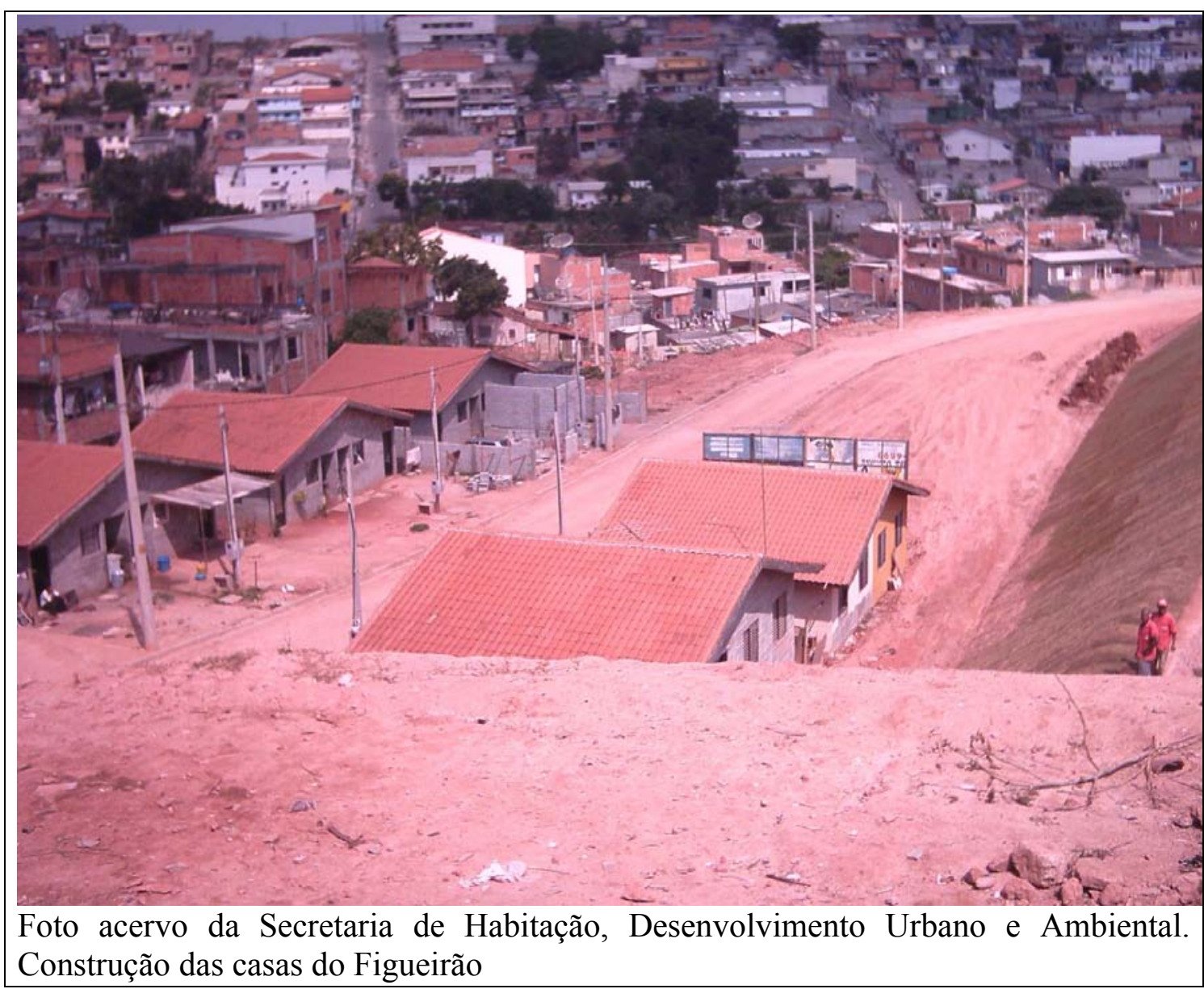

\section{A Urbanização como infra-estrutura - Obras na Vila da Amizade}

A Vila da Amizade é uma grande ocupação numa encosta, em 2001 já se encontrava consolidada, enquanto construção de 
residências. Estima-se que totalizem 800 famílias residentes neste bairro.

Em 2001 conseguimos desencadear as obras de drenagem das águas pluviais, rede de água e captação de esgoto ligadas ao Programa Pró-Sanear (Caixa Econômica Federal e Sabesp) em cinco bairros de Jandira - Pernambuco, João Del Moura, Dolores Paschoalin, Jd. Pedreira e Vila da Amizade. Este programa estava previsto para o município de Jandira, desde 1998, porém não se conseguia dar início às obras devido, principalmente, à necessidade de obras de contenção, pois estas não fazem parte do escopo do programa Pró-Sanear. Em 2001 a prefeitura assumiu como contrapartida as obras de contenção, e portanto teve início o Pró-Sanear em Jandira.

Diante da dificuldade de segurança para a implantação da rede de água e de captação do esgoto, a população da Vila da Amizade ficou quase três anos sem acesso ao serviço público de saneamento básico com as verbas para investimento disponibilizada, porém, condicionada ao comprometimento da Prefeitura em assumir as obras de contenção. 


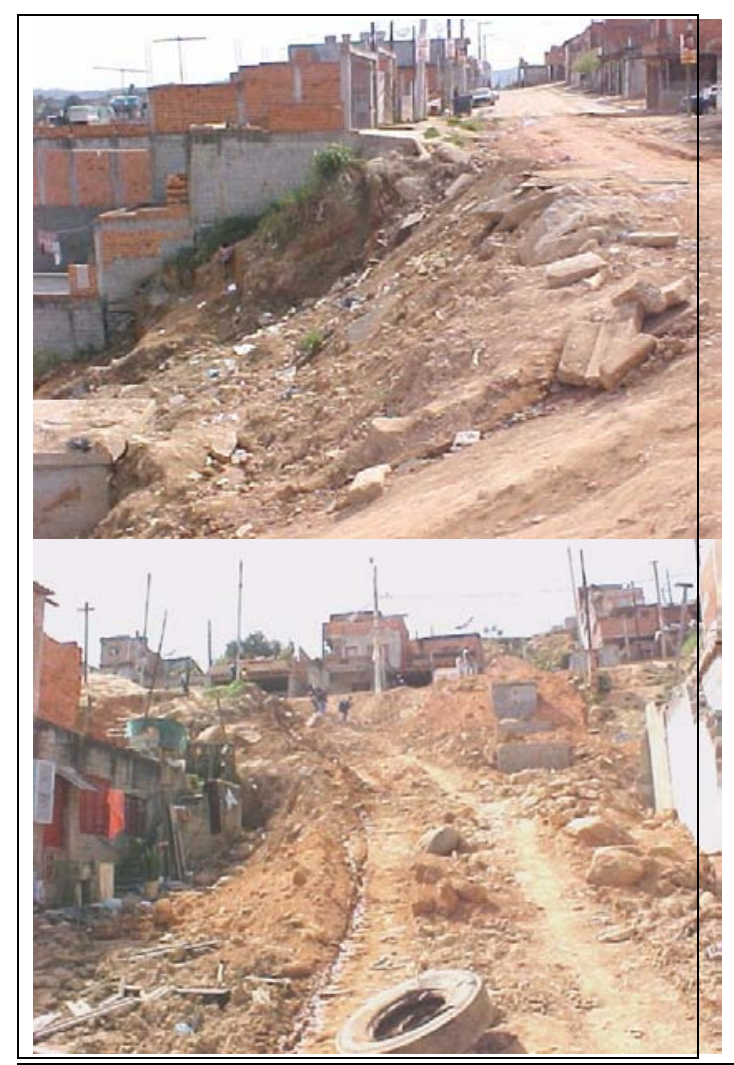

Fotos: acervo da Secretaria de Obras da Prefeitura de Jandira.

Rua Maria Joana Leopoldina (antiga Rua Um) antes da construção do Muro de Arrimo

As obras de contenção prioritárias foram aquelas que garantiriam a sustentação dos leitos das ruas, pois, quando da ocupação, não existia sistema de arruamento. Os acessos para os terrenos eram trilhos que futuramente tornar-se-iam ruas. A prioridade para os leitos das ruas deu-se por conta de ser condição mínima de execução das obras do Pró-Sanear, que necessita, além da demarcação, um mínimo de segurança para a preservação das redes instaladas. 

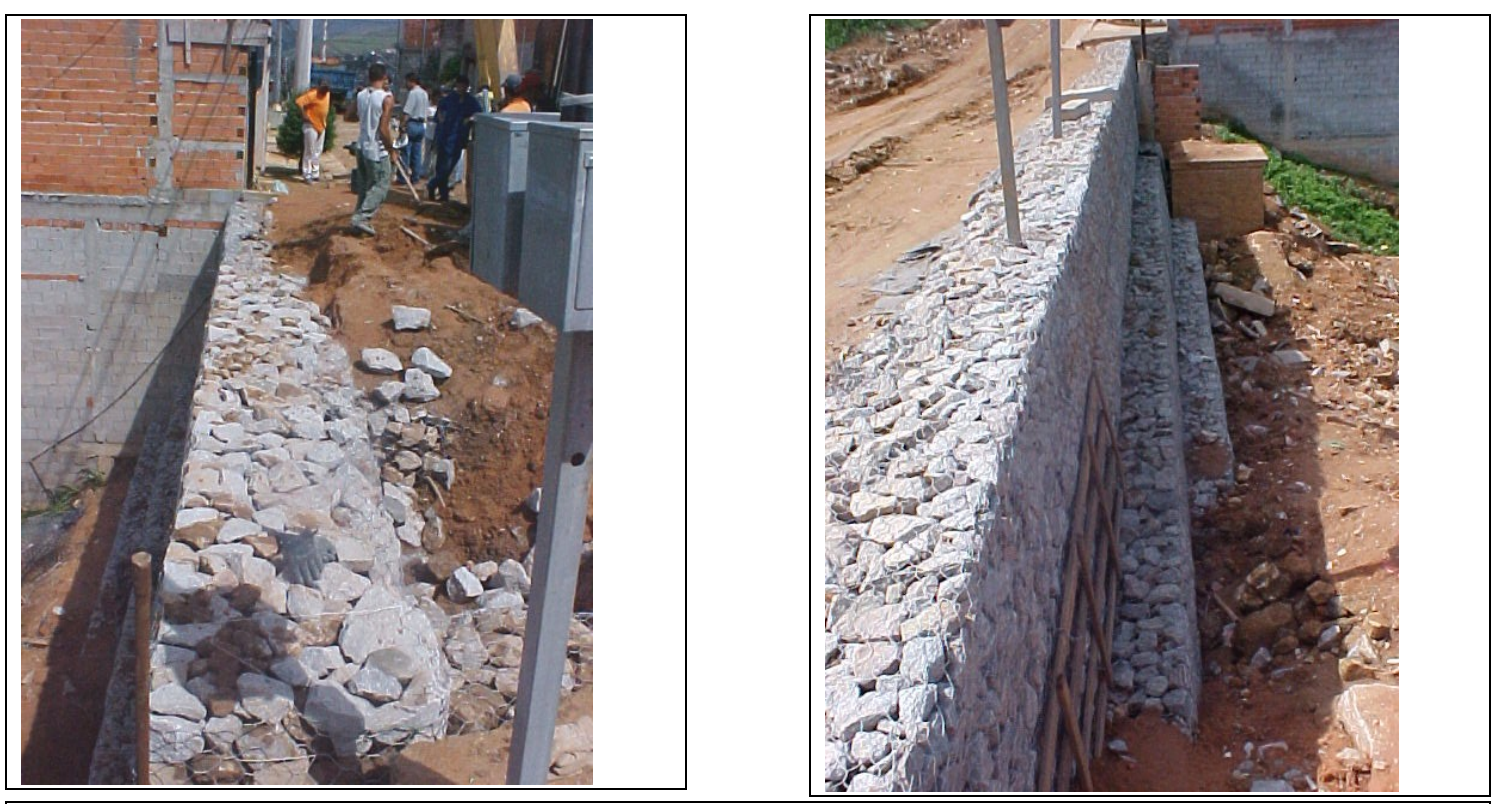

Fotos do acervo da Secretaria de Obras da Prefeitura de Jandira. Arrimos em gabião construídos na Vila da Amizade. 
Além das contenções, o arruamento também deveria ser objeto de investimento, como pode ser observado nas fotos que seguem.
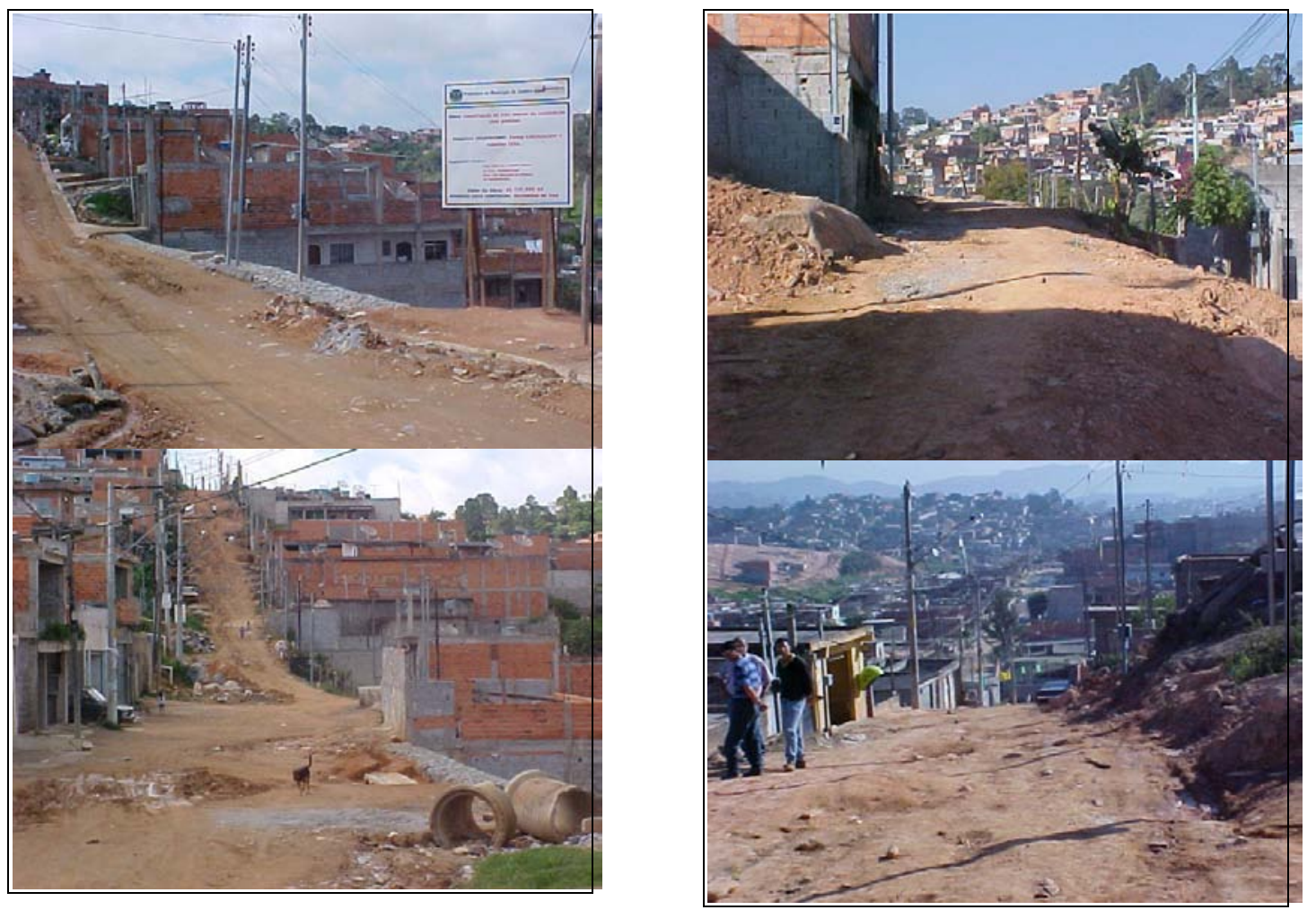

Fotos do acervo da Secretaria de Obras da Prefeitura de Jandira.

Vista das ruas que necessitavam ser pavimentadas. Pode-se perceber a dificuldade de movimentação de máquinas devido ao avanço, pelas construções, sobre onde seria o leito das vias.

Comparando com as fotografias anteriores, as próximas fotos demonstram a importância da infra-estrutura como saneamento e facilidade de acesso. 

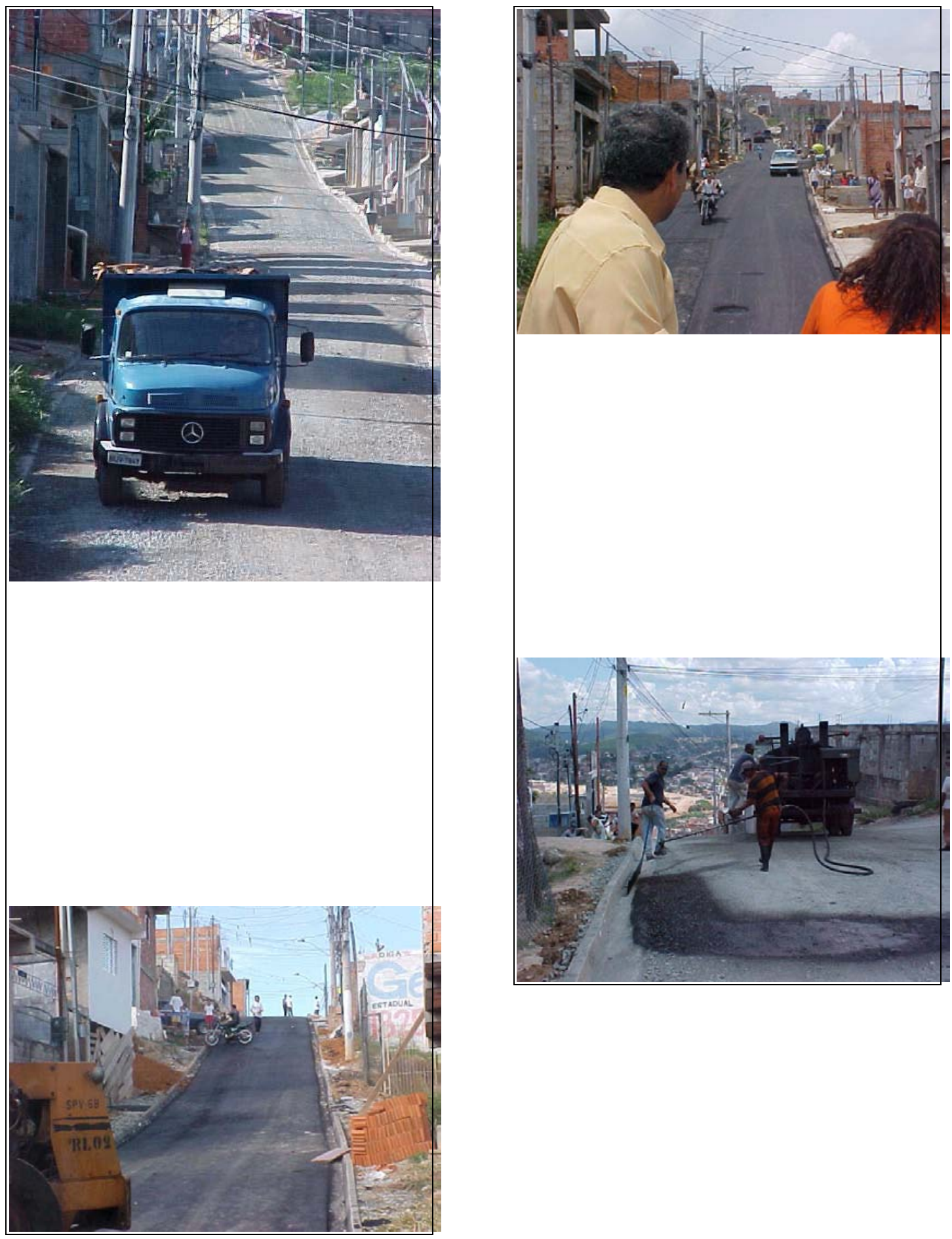

Fotos do acervo da Secretaria de Obras da Prefeitura de Jandira. 


\section{Ambientes de autoconstrução, a conveniência do real?}

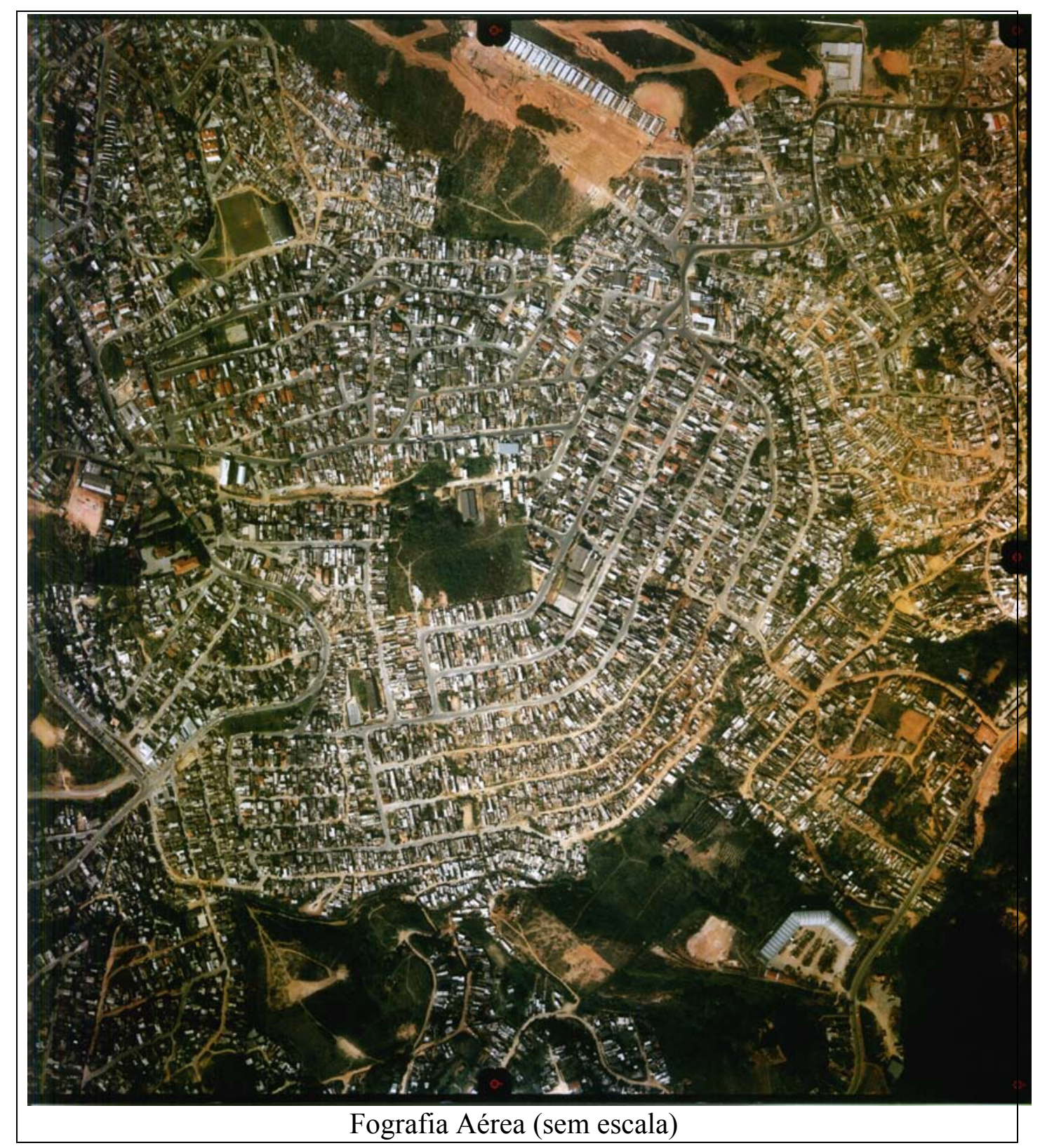

Fotografia aérea, em destaque a Vila da Amizade (sem

escala - devido a necessidade de redução): uma ocupação em

área particular do município de Jandira - Foto Aérea de 1998.

nela é possível perceber o entorno todo asfaltado e quatro 
ruas sem pavimentação: Maria Joana Leopoldina (antiga rua 1), Francisco Batista de Oliveira (antiga rua 2), Rua 3 e rua XV de novembro (o prolongamento sem pavimentação é resultado da ocupação). Ao sul, vemos o município de Itapevi com outros arruamentos sem pavimentação e algumas áreas sem ocupação. Observem que o tecido urbano periférico rompe limites administrativos

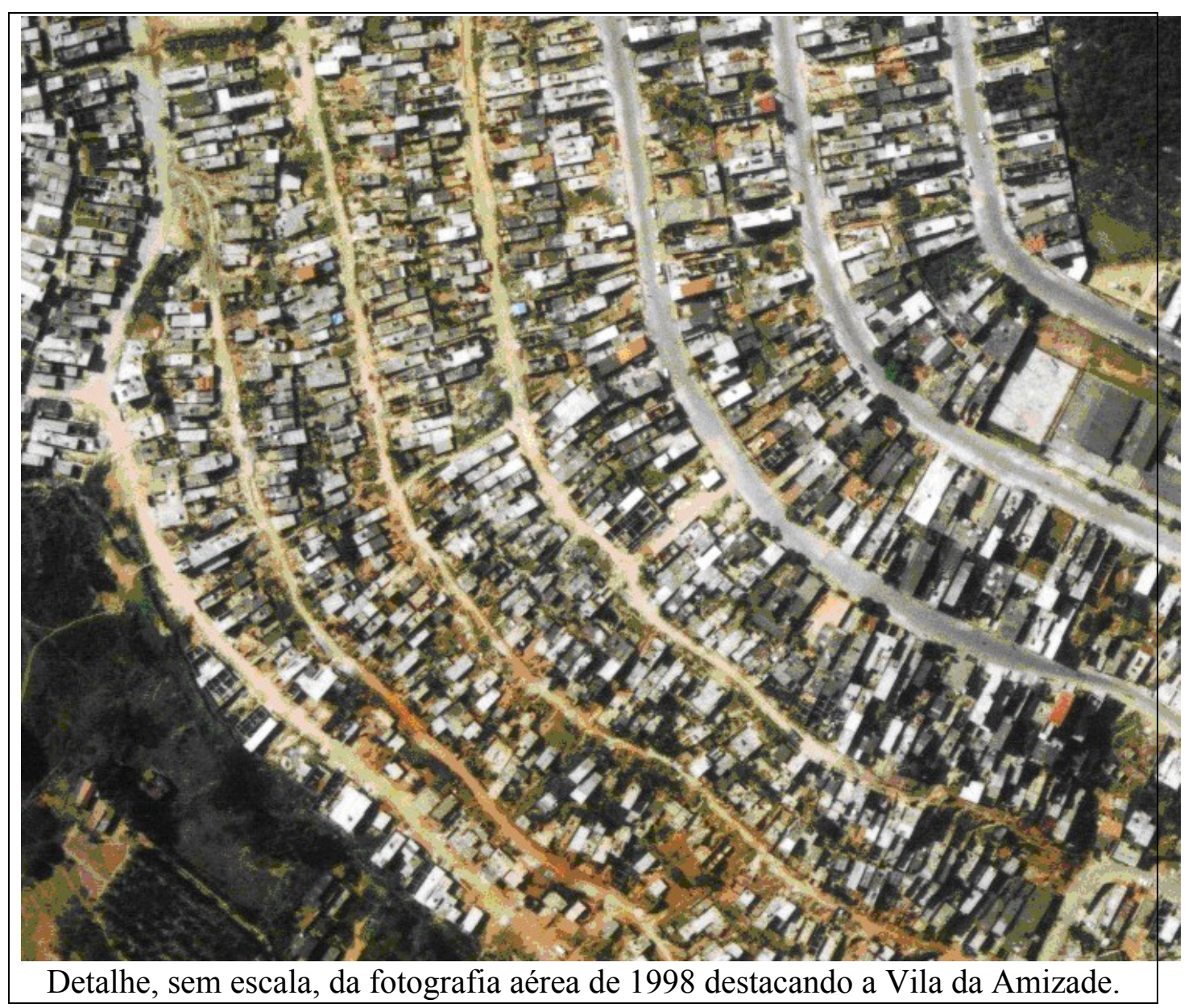

Ao nível da observação/comparação podemos perceber a diferença de uma ocupação irregular de uma área privada, oriunda de um movimento organizado, e outra em área 
pública, também irregular, promovida pelo clientelismo político, como o entorno do campo do Figueirão.

No Figueirão as casas foram surgindo sem demarcação de terreno. Visto de cima, a partir da fotografia aérea, vê-se muitos telhados "amontoados", os acessos são estreitos e muitas construções somente possuem confrontação com construções, necessariamente passar-se-á pelo "quintal" de alguma residência para alcançar as que não possuem confrontação com os acessos.

A Vila da Amizade é uma ocupação organizada que parcelou uma gleba privada. Na década de 1980 a área estava abandonada. Várias famílias fizeram muitas reuniões antes de entrar no terreno, demarcá-lo em lotes de $125 \mathrm{~m}^{2}$, com frente para caminhos que tornar-se-iam ruas.

Atualmente a ocupação original da Vila da Amizade possui abastecimento regular de água, rede de captação de esgoto, guias sarjetas e asfalto, com exceção de um trecho da rua Francisco Batista de Oliveira que por falta de muros de arrimos, ainda, não foi possível a execução de guias, sarjetas e asfalto. Parte da drenagem e dos arrimos ainda está por ser executados e as casas, em sua maioria, possuem aspecto de inacabadas. 
Na ocupação oriunda do clientelismo político, Figueirão, as casas surgiam independente de um traçado viário sem preocupação sequer com o acesso, era a casa exclusivamente. E ainda tinha-se a constante preocupação de que por algum motivo a fiscalização resolvesse atuar e, portanto, impedir que, aquela família, concluísse a construção. No caso da Vila da Amizade já existia estratégia organizada para o enfrentamento com os fiscais, era um coletivo. O movimento é conjunto, as ações são organizadas, nenhuma família está sozinha.

Ao nível da paisagem está expressa a diferença da forma da ocupação. No momento da ocupação construía objetos diferente, num o objeto era a casa, noutro construía a vila. Num as atitudes eram individuais, noutro era coletiva. Em ambos era um enfrentamento que motivava, porém num o enfrentamento estava ao nível das necessidades elementares e noutro além do imediato projetava-se uma coletividade.

Depois de que aquela gleba foi ocupada, com a quase totalidade dos lotes construídos. Depois de enfrentar, declividade, matacões, correntezas provocadas por fortes chuvas... Após inúmeros conflitos, com o proprietário, com a prefeitura, na associação... Com o assassinato de um dos 
líderes da ocupação, enfim, com uma história de luta, com as conquistas dos terrenos, das construções, da infra-estrutura... temos o bairro da Vila da Amizade na mesma condição que boa parte dos outros bairros de Jandira: ambientes de autoconstrução aguardando, principalmente a regularização fundiária.

Tanto o Jd. Figueirão (área pública), quanto a Vila da Amizade (área privada) como vários outros bairros originados de loteamentos irregulares apresentam como principal demanda a titularidade da posse/propriedade do terreno e das construções. A população por sua conta e risco já construiu mais que suas casas, construíram os bairros, a cidade de Jandira foi construída pela sua população, somos um denso ambiente de autoconstrução.

Uma tese possível sobre o espaço da periferia urbana é que, talvez, se pensarmos ao nível da tríade concebido percebido - vivido, os ambientes de autoconstrução podem também ser interpretados como uma demonstração da limitação do Estado no sentido da organização total da sociedade.

Existe uma preocupação muito grande entre os planejadores, mesmo os com vínculos com os movimentos 
sociais, sobre a "informalidade" na produção do espaço urbano. Esta preocupação não pode ser necessariamente transposta como uma visão contrária aos periféricos, aliás, existe a leitura que expressa a oposição entre o "legal e o real" na periferia. Inclusive as lutas do Fórum Nacional de Reforma Urbana e outras conseguiram transformar em lei esta visão dual da cidade, pois a lei federal 10.257/01, "Estatuto da Cidade", também cria instrumentos de regularização que "corrigiria" esta dualidade.

Será que é um movimento do real, a necessidade de correção da oposição entre o legal e o real? O real também não poderia ser uma insurgência intrínseca ao que é estabelecido como legal? Ou melhor, não haveria um movimento real contraditório à regulação do ritmo das pessoas e do espaço urbano? Os ambientes de autoconstrução poderiam ser interpretados como uma alternativa de controle dos citadinos pelo uso do solo?

As legislações de uso do solo geralmente expressam o existente, ou adequam os interesses dos grandes proprietários ao que aparece como determinação do poder público. 
Os lugares de autoconstrução podem ser considerados como contrariação ao legal, a auto permitida pelo poder de fiscalização, pelo fato deste ter deixado construir sem instrumentos legais. Ora quem deveria ter pedido os documentos, para não permitir uma ilegalidade que depois aparece como realidade?

Não seria uma necessidade, para a manutenção dos instrumentos de regulação urbana, a produção das periferias? O Estado daria conta da necessidade de moradia, sem os milhões de ilegais? Ou melhor, a ilegalidade não seria uma válvula de escape para contradição não se tornar explícita?

A partir dos instrumentos criados pelo Estatuto da Cidade e da obrigatoriedade de que os municípios com mais de 20.000 habitantes adequem ou aprovem Planos Diretores Participativos, até outubro de 2006, tivemos uma série de instrumentos que começaram a ser disseminados com muita freqüência (operações urbanas, direito de preempção, consórcio imobiliário...). Estes instrumentos possibilitariam, no âmbito municipal, modernizar o Estado, criando alternativas, sob o álibi da regularização de ampliação da quantidade de proprietários "regulares" da terra urbana. Esta titularidade colocaria estes ambientes na condição de 
patrimônio, ou propriedade. Na situação que nos encontramos, frente ao processos de produção e reprodução das relações sociais de produção, podemos localizar, aí, também, um processo de valorização do espaço, que pode terminar por expulsar, pelo preço, a população hoje residente.

Amélia Damiani localiza como um processo político de produção do espaço metropolitano:

"O que, para nós, é significativo é, entre os instrumentos institucionais de constituição do território da ação estatista, no urbano, o Estatuto da Cidade, que, por sua vez, também é o instrumento evocado na constituição do espaço do projeto político, espaço a revelia do território da ação estatista, quando esta alimenta novas faces da economia urbana, como parte implicada na mercantilização do espaço, que inclui a produção material do espaço e a financeirização econômica, como seu desdobramento necessário. Embora nesse caso, o do Estatuto da Cidade, o plano diretor do município constitua o instrumento primordial, há uma perspectiva de configuração metropolitana do território da ação política, do ponto de vista da articulação do município com aqueles que o rodeia; no caso das metrópoles, sua condição de centralidade de um processo social que transcende o município, como instância política." ${ }^{\prime 31}$

\footnotetext{
${ }^{31}$ Damiani. Amélia Luisa. A metrópole na dialética entre o território de ação estatista e o espaço de projeto político. Mimeo. p. 09
} 


\section{Os Limites da Urbanização}

Uma situação limite nas grandes cidades brasileiras é a produção das áreas de risco, isto é, a ocupação de encostas ou várzeas por moradias.

Nesta situação, temos vários elementos críticos, reveladores do processo de produção e reprodução das relações sociais de produção.

É na periferia dos grandes centros urbanos onde se concentram as maiores aglomerações de pessoas morando em áreas de risco, talvez esta afirmação possa parecer uma obviedade, porém aqui temos a limitação, se é obvio, por que ocorre? Ou melhor, por que é recorrente, independente do lugar no território brasileiro? A obviedade não seria um alerta ou uma demonstração de uma lógica na qual está inserida uma situação que pode ser reveladora do limite da urbanização?

No dia-a-dia das grandes cidades é corriqueiro ouvir referirem-se às encostas ou às várzeas como áreas livres. Ora se são livres, por que não ocupá-las?

As chamadas áreas livres são resultado de processos de parcelamento do solo urbano que, por algum motivo, não foram definidas como lotes, que poderiam ser postos à venda, 
e normalmente ficam sob o domínio do poder público. $\mathrm{Na}$ maioria dos casos são áreas non aedificandi, institucionais, sistema de lazer, ou áreas verdes, resultantes de algum procedimento de formalização do parcelamento do solo.

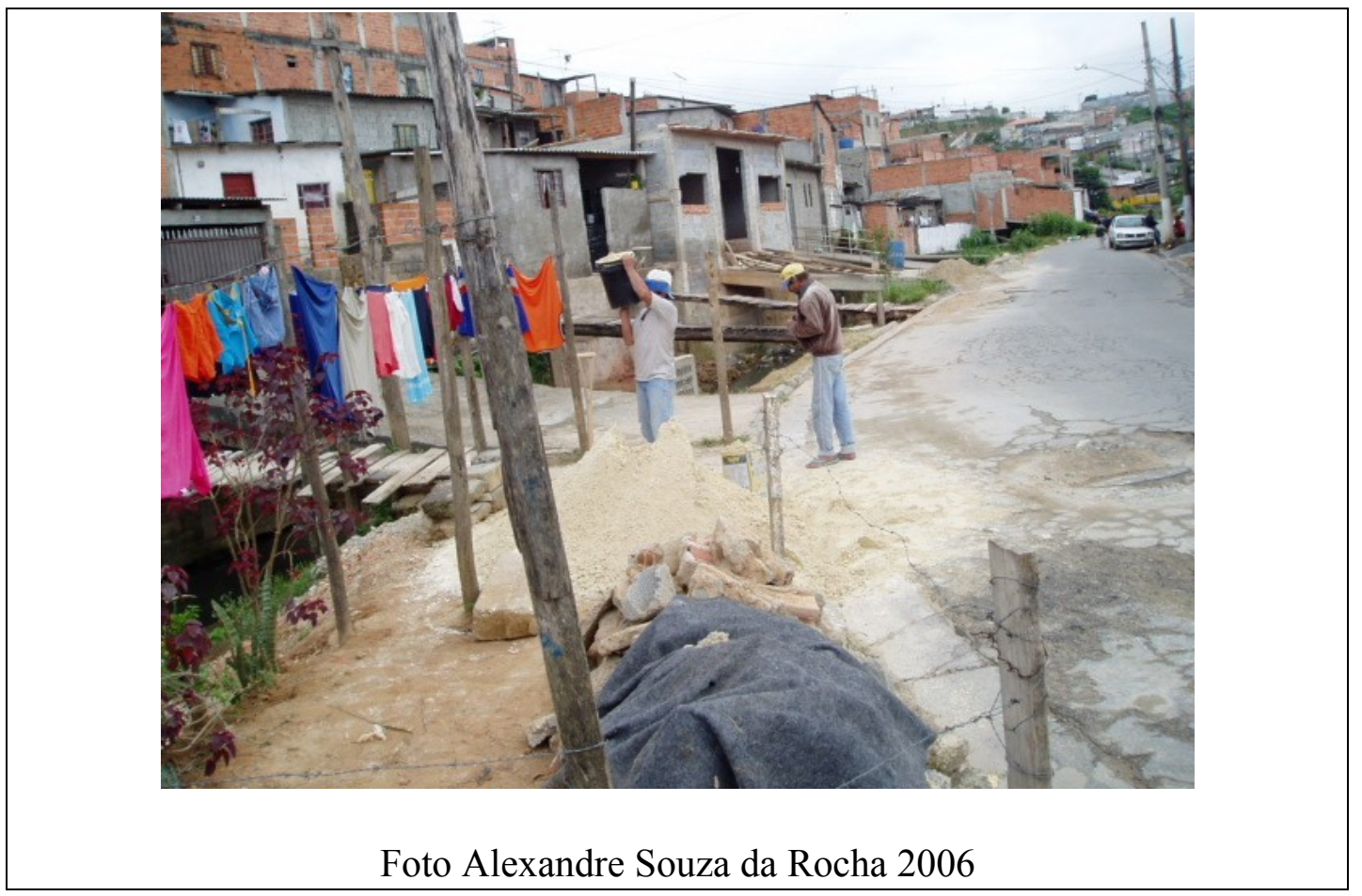

A foto mostra área densamente ocupada, na divisa do município de Jandira e Itapevi, na altura do Córrego Barueri Mirim. A rua é em Jandira e as casas são em Itapevi. O acesso às casas é por pinguelas de madeiras ou passarelas de concreto. Durante fortes chuvas muitas das pinguelas são levadas pela correnteza. As passarelas de concreto, muitas vezes, retêm uma grande quantidades de objetos trazidos pela correnteza, produzindo inundações à montante.

A legislação vigente (lei 6766/79, alterada pela lei 9875/98, ou o Código Florestal) indica uma exigência de que 
ao longo dos cursos d'água ou de suas nascentes, deve ser mantida, em cada margem, faixa non aedificandi de no mínimo 15 metros $^{32}$.

Nos loteamentos também são exigidos um percentual da gleba para uso institucional. Em muitos casos, são as piores áreas, principalmente, pela clinografia, que ficam como de uso institucional. Esta destinação é resultado, principalmente, do conluio entre o poder público, o responsável por estabelecer as diretrizes para o parcelamento do solo, e os grandes proprietários e empreendedores. Nesta mesma situação, temos a destinação de sistema de lazer ou áreas verdes.

Em muitos casos, a destinação de área pública, que depois vai ser interpretada como livre, ocorre nos terrenos com piores situações clinográficas ou sujeitos a inundações.

Por que alguém iria colocar-se em situação de risco? Desconhecimento?

Não existe nada de lúdico ou telúrico nos ambientes de moradia na beira do rio, as casas são construídas com o rio no fundo, não com o rio ao fundo. A área que devia estar livre para os períodos de cheia, além de desmatada, ganha uma

3215 metros é o mínimo de faixa non aedificandi que a lei federal 6766/79 exige para as margens de qualquer curso d'água natural, no Código Florestal, o mínimo é 30 metros. Para áreas de nascente, o mínimo é 50 metros de raio 
impermeabilização, que acelera processos de percolação e assoreamento. Com as margens ocupadas, dificulta-se o acesso de máquinas e o trabalho de limpeza e desassoreamento fica ainda mais comprometido. A vegetação que, nas bordas das barrancas, funciona como resistência aos processos de desbarrancamento, quando removida, deixa o talude exposto ao atrito com a correnteza, com um agravante: as casas têm suas estruturas apoiadas nesta beirada, agora muito mais facilmente erodida.

Muitas discussões sobre as áreas de risco apresentam a situação como "tragédia anunciada". É um problema de responsabilidade do poder público que permitiu a ocupação de áreas suscetíveis a risco de desmoronamento ou inundação. Acredito na possibilidade de apresentar a situação das áreas de risco como um dos elementos dos limites da urbanização. Ao nível deste trabalho fica a pretensão da reflexão. 


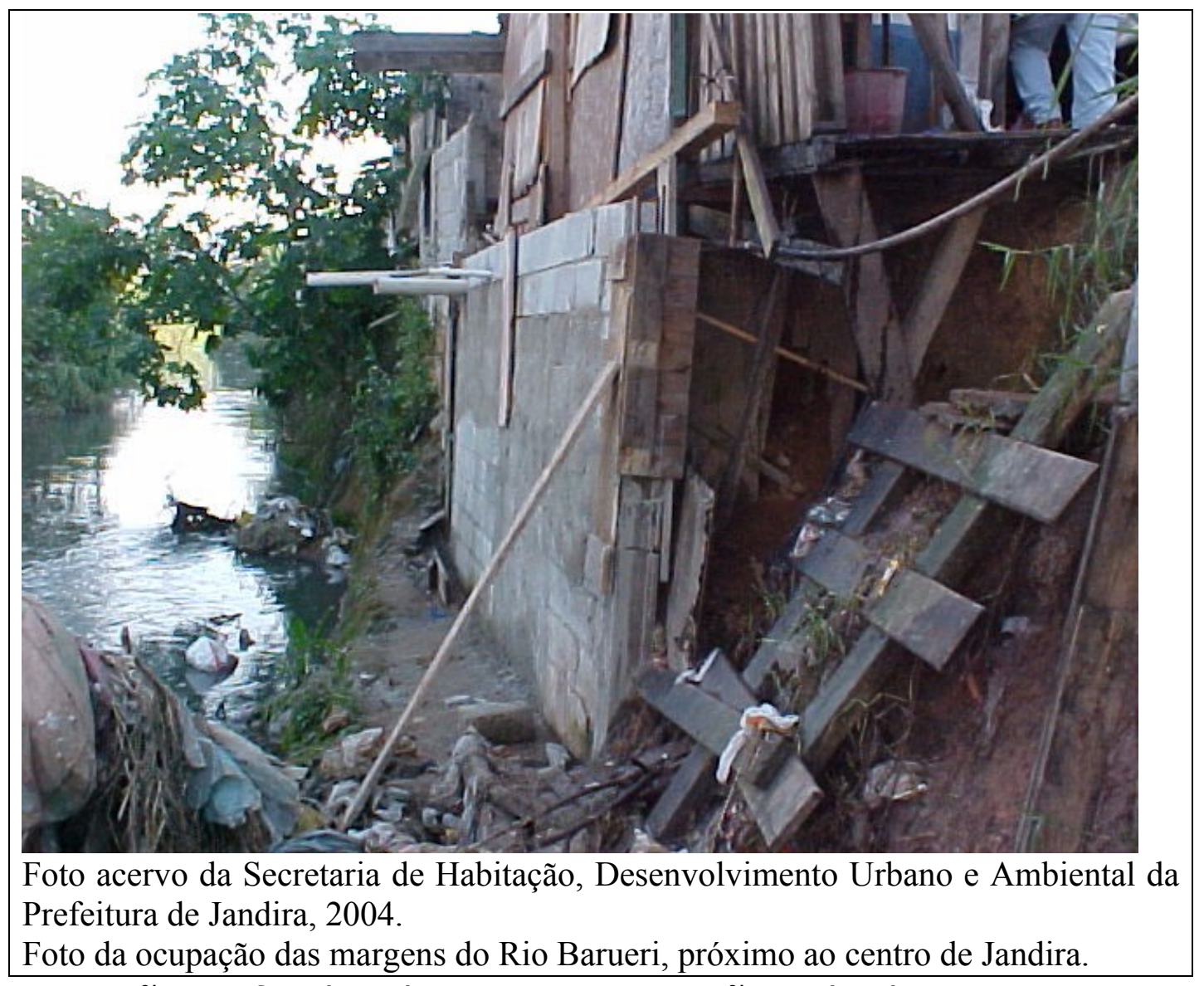
São os fundos das casas que estão voltados para o rio. 


\section{Os "bicos"}

... "O tecido urbano, o das redes múltiplas de comunicação e de trocas, faz parte dos meios de produção. A cidade e as instalações diversas (postes, estações, mas também depósitos e entrepostos, transportes e serviços diversos) são capital fixo. A divisão do trabalho penetra o espaço inteiro (e não apenas 'o espaço de trabalho', o das empresas). Consome-se o espaço inteiro produtivamente da mesma maneira que edifícios e locais industriais, as máquinas, as matérias-primas e a própria força de trabalho." ${ }^{\prime 33}$

No mundo da sujeição de todos aos imperativos do dinheiro, os que não conseguem incluir-se através da carteira assinada, para ter a exploração de sua força de trabalho como troca para adquirir os meios de vida, ficam na clandestinidade do mundo do trabalho, sujeitados a acasos que os possibilitem adquirir algum recurso para suprir seus meios de vida. Os "bicos" nos ambientes de autoconstrução são uma

\footnotetext{
${ }^{33}$ Lefebvre, Henri. A Produção do Espaço. Mimeo - Tradução grupo de estudos do Labur. p.87.
} 
forma de reprodução da cidade e também de pessoas que estão "informalizadas" no mundo do trabalho.

Através de empreitadas, arranca-se barranco, e vertentes são modeladas em degraus formando patamares onde "brotam" casas. Nos ambientes de autoconstrução, um profissional que abunda é o pedreiro, bem como o servente, este está sempre à espera de conseguir um emprego, ou numa empresa da construção civil ou como ajudante geral em qualquer tipo de trabalho; enquanto isso não acontece, fica disponível para qualquer serviço. Os pedreiros com experiência comprovada, aqueles que, pelo resultado do seu trabalho, mostram-se para a comunidade como mestres de ofício, constituem-se como profissionais extremamente requisitados, principalmente, em lugares que não necessariamente sejam periferia. Estes sempre "têm trabalho" ${ }^{34}$, raramente com alguma formalização, mesmo nos condomínios fechados da classe média, são contratados para alguma empreitada e após sua conclusão nenhum vínculo empregatício ou outra relação formal permanece.

Pintores de paredes, eletricistas, marceneiros, mecânicos, funileiros, e uma série de outros profissionais que estão à espera de uma formalização no chamado mercado de 34 "Pedreiro bom não fica parado" é um ditado comum nestes ambientes. 
trabalho, colocam-se à disposição do entorno para incluíremse no mundo do dinheiro com algum dinheiro.

No "mundo do dinheiro sem o dinheiro" aparecem "alternativas" que incluem o que aparentemente estaria de fora: "quem não pode não se estabelece" é um dito com pouca verossimilhança nas periferias do mundo da mercadoria $^{35}$. O estabelecimento de alguma práticaserve como trabalho para suprir os meios de vida, pode ser uma calçada, um muro, uma sala, uma garagem, uma placa ou um cartaz (com erros na língua portuguesa ou não). Vende-se desde especialidades, como as apontadas no parágrafo anterior, até itens de pouco valor unitário (como os "gelinhos"36 nas placas de muitas casas, que custam $\mathrm{R} \$ 0,10)$. Talvez possa ser considerado um exagero a constatação que ora apresento, mas este trabalho levou a ela: com a urbanização da sociedade, as populações "periferizadas" vêem-se imersas no mundo da mercadoria como mercadorias descartadas e, nos limites da necessidade, colocam sua intimidade de lado e submetem-se a levar o trabalho para a

\footnotetext{
${ }^{35}$ A expressão "periferia do mundo da mercadoria" deve ser entendida, neste trabalho, como integrante de movimento que atravessa todos os momentos da vida. Ser periférico não significa estar de fora. Significa uma inclusão que o nega, e ao mesmo tempo inclui. Não necessariamente é uma negação, mas como crise aparece como sua possibilidade.

${ }^{36}$ Sorvetes em saquinhos plásticos produzidos nas cozinhas e geladeiras de um cotidiano que leva para dentro de um cômodo, tradicionalmente considerado íntimo, a mercadoria que os inclui como mercadoria. Os gelinhos também são chamados de "chup-chup" e "juju”.
} 
cozinha de sua casa, inserindo-se assim no mundo da mercadoria. Não é possível afirmar que, no drama do desemprego, este possa ser o lado mais perverso, mas podese aferir que quem tem o emprego fora de casa não submete toda sua intimidade ao mundo do trabalho abstrato. Enquanto que quem transforma uma parte de seu lar aos ditames do processo de reprodução das coisas pelo dinheiro está sob um cotidiano mais perverso, pois, além de viver o limite imposto pelo mundo do trabalho abstrato, "come e dorme" nele. Não existe folga, não existe um lugar separado do trabalho. A família é trabalho, e ao mesmo tempo aparece como não trabalho, ao nível formal que o desemprego representa. 


\title{
Necessidade, desejo e fruição
}

\author{
Necessidade, desejo e fruição ${ }^{37}$. Esta é uma tríade \\ explicativa de várias situações dos ambientes de auto- \\ construção. Os termos da tríade não são autônomos, isto é, \\ em si, cada um deles perde potência de explicação, pois o \\ movimento não pode ser visto pela particularidade de algum \\ desses termos.
}

Não foi somente a necessidade de morar que fez com que as pessoas arcassem com o projeto de construir a própria casa. Aliás, independente do ambiente - auto-construção ou não - muitas pessoas projetam sua casa, porém ao nível formal contratam profissionais para executar o projeto desde o momento teleológico, ou melhor, da concepção à entrega

\footnotetext{
${ }^{37}$ Os termos aqui apresentados têm origem no artigo "Capítulo IV - Psicologia das Classes Sociais" página 28, onde Henri Lefebvre afirma: "Na Crítica à filosofia hegeliana do Estado, Marx examina três aspectos da individualidade não-mutilada, no seio de uma totalidade social também não-mutilada por um pensamento e uma ação unilaterais; esses três aspectos são a necessidade, o trabalho, a fruição" estes seriam termos da dimensão da consciência do ser humano, “...três dimensões. Cada uma delas têm uma realidade própria, que, entretanto, remete às duas outras, aparecendo assim como mediação .... a necessidade remete ao trabalho, que cria e permite a fruição do objeto produzido ou da obra criada" (Lefebvre, Henri. Capítulo IV - Psicologias das Classes Sociais. In Geousp-espaço e tempo Revista de Pós-Graduação / Departamento de Geografia, FFLCH,USP, nº 17.São Paulo: FFLCH/USP, 2005 p.28). Nas preocupações que movimentam esta pesquisa, o termo necessidade é constante e a critica ao mundo do trabalho leva a localizá-lo nos vários momentos e situações, inclusive no morar, já fruição sequer havia sido aventada. Desde antes da elaboração da dissertação "Periferia e Centralidade na Grande São Paulo - Abordagem crítica sobre o morar na periferia da metrópole" (op.cit.) existe a pergunta a periferia pode ser obra? Não localizei obra, mas fruição é um termo pertinente, porém embora, analiticamente, possa ser visto em separado, temos uma relação com um desejo, uma vontade transcendente ao trabalho. Desejo/vontade, termos que serão utilizados conjuntamente, não foi possível melhorar a precisão dos termos, localizou-se o movimento, e não foi o trabalho que ganhou espaço nos ambientes de autoconstrução, ele é uma totalidade. Algo inerente ao ser, sujeito às inúmeras alienações e fetiches, e ao mesmo tempo mobilizador e influente que Nietzche no Nascimento da Tragédia revela suas potencialidades no sentido da humanidade e aí temos situações explosivas das nossas capacidades. No enfrentamento rotineiro que são os ambientes de autoconstrução o desejo e/ou a vontade são fundamentais como capacidade explicativa nesta tríade.
} 
das chaves, será um relacionamento entre clientes e prestadores de serviços. Outra questão a ser apresentada é habitação como uma necessidade básica. Todos, de alguma forma, precisam provir sua habitação.

"Infelizmente, a noção de necessidade, longe de ser clara, não passa de uma elaboração conceitual. Além disso, a experiência e a prática mostram, hoje (salvo prova em contrário), um processo da mais alta importância: a generalização das necessidades. Necessidades análogas surgem em escala mundial, independentemente das diferenças de país, raça, classe, regime político." ${ }^{138}$

Na lógica da produção do espaço metropolitano, alguns lugares foram destinados a ser ambiente de auto-construção. O processo de produção e reprodução social do espaço possui no seu bojo a auto-construção como uma das soluções do chamado déficit habitacional. Se não fosse os milhões de pessoas buscando por conta própria solucionar sua necessidade de morar, nenhum programa habitacional teria feito algum sentido. BNH, Cohabs, CDHU, CEF e outros atendem uma pequena parte da demanda, se todos que precisam morar fossem considerados objeto de atuação do

\footnotetext{
${ }^{38}$ Lefebvre, Henri. Psicologia das Classes Sociais. GEOUSP - Espaço e Tempo nº 17. p.21
} 
Estado, qualquer dos programas citados não teria funcionado, mesmo parcialmente. A situação seria explosiva, pois como necessidade básica a moradia é mobilizadora.

Observemos as fotografias aéreas das nossas grandes cidades, mesmo as que desde seu início propunham-se como planejadas, seus arredores aparecem como anomalia. A idéia de que as periferias sejam uma anomalia do planejamento é uma cômoda aparência. Se não existissem os arredores autocontruídos, aquela população teria lugar no plano? Ora, mesmo não estando na forma do plano, os arredores de "desordem" contribuíram para que o planejado de alguma forma acontecesse. A exclusão de uma parcela da população do plano não foi planejada, é inerente à lógica de funcionamento do modo de produção capitalista. Ao mesmo tempo, interpretar a periferia como exclusão, pura e simplesmente, é perder o sentido das contradições sociais espacializadas no processo de produção da metrópole. As alternativas de habitação surgem a partir do próprio processo de planejamento. As cidades satélites do Distrito Federal são comumente apresentadas como exemplo destas situações, mas os arredores das grandes cidades tornaram-se alternativas de moradias por conta do plano, não como 
anomalia, desordem ou mesmo exclusão, mas como parte do mesmo processo, que é crítico, e traz em si as contradições do processo inteiro. A totalidade do processo de produção e reprodução das relações sociais de produção já contém os objetos, atos e situações críticos das contradições existentes. Nesse contexto, a realidade é crítica, e aí se revelam os momentos contraditórios.

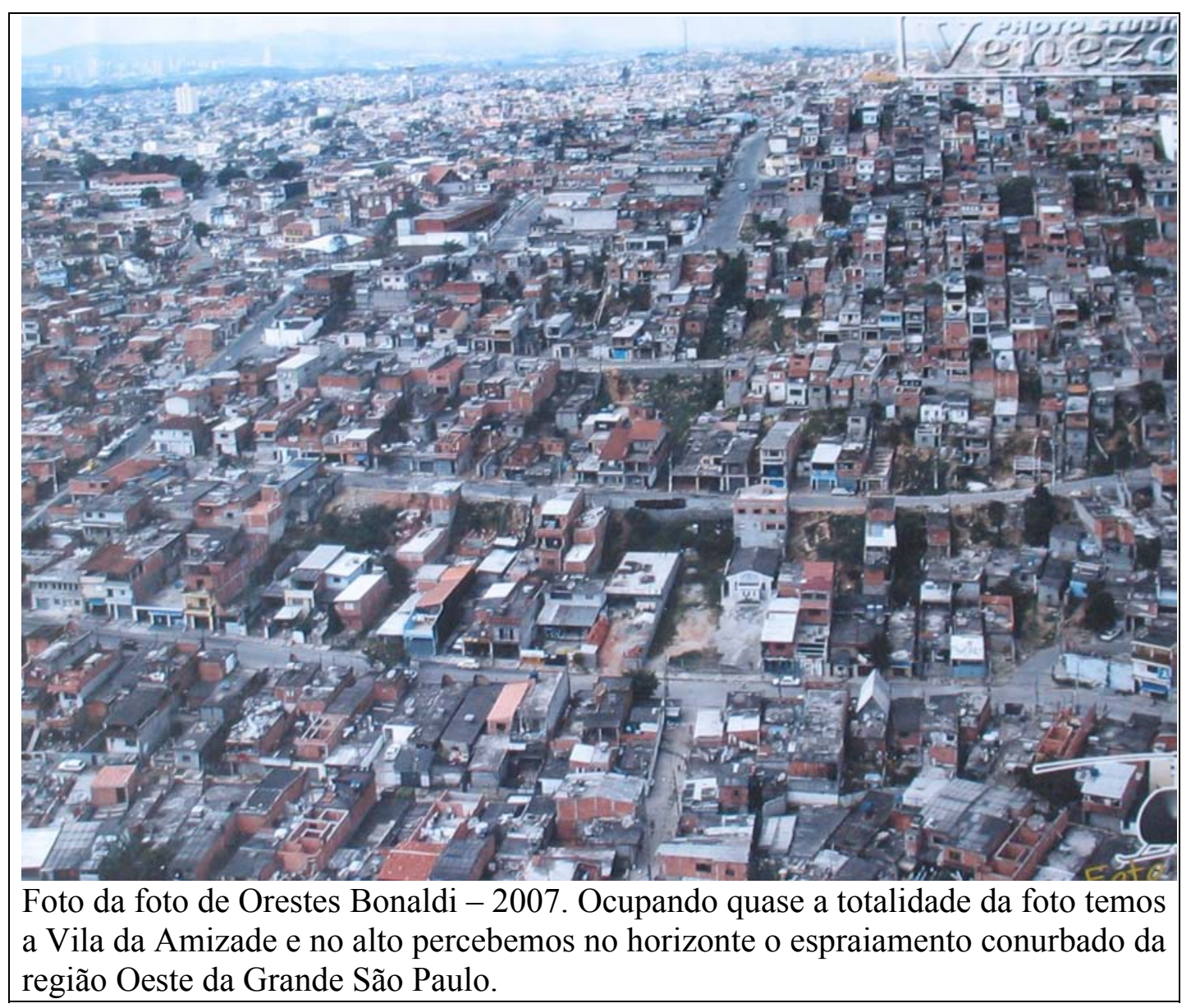

Não há como mensurar, mas somente a necessidade não explica os ambientes de autoconstrução. O desejo é um termo 
da tríade presente nas várias situações que movimentaram as pessoas, não só o limite econômico imperou, também houve um querer, ou seja, de alguma forma não foi uma massa de pessoas movimentada pela necessidade de moradia, que ocupou as periferias nas nossas cidades. Além do movimento do Estado e do Capital, que impulsionaram os processos migratórios do nosso país, as pessoas arrastadas pelo processo de urbanização em algum momento do enfrentamento da vida vivida estabeleceram parâmetros de escolha. Não foi somente uma massa amorfa mobilizada na acelerada urbanização do país. Como indivíduos, ainda que residual ou subjetivo, o desejo é um motor das atitudes, mesmo sob as influências imperiosas do econômico, existe uma particularidade que vem dos relacionamentos interpessoais, de uma história (com h minúsculo) constituída por objetos, atos e situações oriundos do cotidiano ${ }^{39}$. Temos comunidades formadas por sociabilidades estabelecidas na "terra natal", (como os piauienses em Carapicuíba); as relações de parentesco; ou a partir das relações de trabalho, pessoas de uma mesma fábrica ou ramo de atividade estabelecem-se como vizinhos, e nesse mesmo sentido

${ }_{39}$ A idéia de processos históricos diferenciados entre uma História (H maiúsculo) referente a processos hegemônicos, e outra história (h minúsculo) atinente às pessoas comuns e ao cotidiano, é baseada no livro Subúrbio do professor José de Souza Martins. 
proximidade dos postos de trabalho também pode ser 0 mobilizador para a escolha de onde construir sua casa.

Não é o desejo sem fim, mas o desejo capaz de mobilizar esforços, às vezes inacreditáveis. Dezenas de dias para demolir um matacão, com fogo e marreta, poderiam sugerir a necessidade como mobilizadora do trabalho. Pode ser, mas outros não removeram o matacão, desviaram ou construíram sobre. Algo de estético ou de preferência foi mobilizador de esforços.

$\mathrm{Na}$ intensidade da vida vivida, a preponderância das necessidades é mais um dos enfrentamentos, desafios são encarados como ritmo do dia-a-dia. O mobilizador não é a dificuldade. O universo do desejo propicia a ampliação da interpretação, não é explicito, está no âmbito da subjetividade, e imerso nas inúmeras alienações. Seria inexplicável a intensidade da vida nesses ambientes, sem o desejo como mobilizador. Não são somente pessoas inertes, movimentadas pelo limite, pr[oprio da necessidade econômico da necessidade.

O âmbito do desejo é inerente ao processo, pelas atribulações que cada família enfrenta no processo de construção de sua moradia. A satisfação, o querer tem que 
ser contemplado. Em Jandira, é comum ouvirmos esposas reclamando da escolha do marido sobre o local onde moram e, ao mesmo tempo, o "era o possível no momento". O império do econômico aparece como determinante, mas, em vários casos, o que explica a escolha do lugar onde empreender todos os seus esforços na construção da moradia passa por outros âmbitos. O patriarcalismo e o machismo possuem maior capacidade de esclarecimento. O poder do "homem da casa", o desejo de estar longe da família da esposa também é explicitado pelos maridos. Nesta situação seria o sociológico mais preponderante que o econômico.

Mas para compreender os ambientes de autoconstrução necessidade e desejo não explicam o dia-a-dia, o como é feito. A fruição, como gozo e usufruto, permite-nos aproximação com o praticado, o espaço é usado, usufruído, ao limite. A ocupação total do lote, ou a falta de recuo entre as construções, pode ser interpretado como abuso. Porém, acredito que a fruição apresenta melhor potencial explicativo, pois os excessos não estão exclusivamente no terreno, o entorno e as áreas de uso coletivo estão sempre em foco pelo extremo usufruto. Os entulhos são depositados na calçada ou em terrenos baldios das proximidades, os sacos com lixo são 
atirados pela janela no córrego que a residência margeia, águas pluviais e servidas são conduzidas na mesma rede, aparelhos de som no último volume independente do horário e outras controvérsias são práticas resultantes de um uso abusivo do ambiente construído. Vai além de noções morais de certo e errado, todo mundo que joga o lixo pela janela de sua casa direto no córrego sabe que está prejudicando o seu local de moradia, e os argumentos são sempre os mesmos: "não sou só eu". Pela lógica é prático, e outros fizeram primeiro, por que não fazer? Não bastam noções morais para compreender esta situação. É mais que alienação, é fruição.

Os programas de urbanização de favelas enfrentam como normatização. Assistentes Sociais organizam reuniões, fazem dinâmica de grupo discutindo e apresentando os objetivos do saneamento básico e a "necessidade da colaboração de todos". Os moradores participam, criticam e propõem, e geralmente o conflito já era sentido no dia-a-dia. As soluções apresentadas geralmente sugerem uma atuação do poder público para coibir os excessos.

Projetos de educação ambiental são promovidos para as populações residentes nas beiras dos córregos, têm objetivo de "conscientizar" a população sobre a preservação do meio 
ambiente, mas falta a compreensão do processo. A questão não é de consciência ambiental. O ambiente e as pessoas fazem parte do mesmo processo que é econômico, social e político. Sem essa compreensão continuarão a existir projetos tentando ensinar pobre a ser limpinho. Não é uma questão estrita de higiene, vai mais além. Em Jandira, a Sabesp despeja in natura nos corpos d'água todo o esgoto que recolhe, e cobra o mesmo valor da tarifa de água tratada para o esgoto.

Mesmo não sendo um movimento ou um processo de consciência, é possível pensar que, se uma empresa governamental pode pegar todos os dejetos líquidos à montante e despejar no rio que corre junto às casas por que o morador não poderia?

O "cada um deve fazer sua parte" dos "conscientizadores" não é muito convincente para quem vive junto à sujeira que em boa parte não foi ele quem produziu. $E$ se for questão de higiene, o rio leva a sujeira que foi posta no saco de lixo. Geralmente as casas estão limpas e higienizadas, sendo corriqueiro donas de casa criticarem a falta de limpeza do entorno e compararem com a casa dela, que está cuidada. 
A dimensão do ser humano, nos termos de Lefebvre em "psicologia das classes sociais" ${ }^{40}$ hoje está inserida numa série de mediações e alienações com destaque ao trabalho cada vez mais subsumido à exacerbação da extração de mais-valia relativa, e para o trabalhador acrescenta-se uma continuidade da mais-valia absoluta no processo de construção da sua moradia. A satisfação dos "meios de vida" é parte da necessidade do trabalhador.

O império do trabalho prolonga-se, relativizando-se os momentos, diluíndo-os na continuidade da produção. Esta é uma situação crítica nos ambientes de autoconstrução. Podemos ver estes ambientes como um prolongamento do mundo do trabalho. Mas não basta para explicá-los, e dado que:

"O desenvolvimento do modo de produção capitalista depende de uma transformação das forças produtivas do trabalho. O capitalismo desencadeia o desenvolvimento das forças produtivas do trabalho - desenvolvimento das técnicas, das capacidades de trabalho, das ciências, voltado à produção -, tornado contraditoriamente desenvolvimento das forças produtivas do capital. A produção de mais-valia relativa se define com a modificação real do modo de produção, 
constituindo-se um modo de produção especificamente capitalista. Trata-se de um modo de produção tecnologicamente específico, que transforma a natureza real do processo de trabalho e suas condições reais; dá-se a submissão real do trabalho ao capital. A submissão real equivale a uma revolução na produtividade do trabalho e na relação entre o capitalista e o trabalhador à base do desenvolvimento das forças produtivas sociais do trabalho, constituído pelo aumento do volume de produção, acréscimo e diversificação das esferas produtivas e de suas ramificações. Então, a produção pela produção, tornada uma finalidade, a produção como fim em si mesma, na relação capitalista, se realiza de maneira adequada: subverte-se assim o sentido da produção. Não se produz para necessidades, mas para o aumento da produção.O processo de produção, como processo de produção de mais-valia, é a expansão do mundo da mercadoria. As mercadorias, que têm como elementos constitutivos o valor de uso e o valor de troca, carregam no valor a mais-valia produzida, através da exploração do trabalho. Assim, produzir para realizar a troca passa a ser uma necessidade para a realização dessa mais-valia. As duas formas de mais-valia, a absoluta e a relativa, têm a primeira 
forma como precursora, mas 'a mais desenvolvida, a segunda, pode constituir, por sua vez, a base para a introdução da primeira em novos ramos de produção.' As duas formas de mais-valia são, ao mesmo tempo, sucessivas e podem se realizar simultaneamente. Esta consideração é muito importante para decifrar as reais condições de trabalho em cada ramo de produção e nos diferentes ramos de produção. Com o desenvolvimento da divisão do trabalho é possível observar, para produzir dado produto, a relação entre ramos produtivos que produzem de modos diferentes, havendo nuns a extração da mais-valia absoluta e noutros a extração da mais-valia relativa. A produção de um mesmo produto pode reunir essas duas formas de mais-valia. ${ }^{\prime 41}$

Como continuidade do processo de produção do trabalhador como força de trabalho, o trabalho é necessidade, e a necessidade já está contemplada na tríade. E o trabalho, que seria um dos termos, é necessidade dentro do contexto apresentado. O desejo é o termo que apresenta mediações relacionadas ao ambiente de autoconstrução com potencial explicativo complementar ao universo da necessidade. É obvio

\footnotetext{
${ }^{41}$ ALFREDO, Anselmo e outros. O Futuro do Trabalho: Elementos para a discussão das taxas de mais-valia e de lucro. AGB/SP, Labur/Programa de Pós-Graduação em Geografia Humana, DG/FFLCH/USP.São Paulo: 2006. pp.11-12, citação de Marx em O Capital, livro 1, Capítulo VI (inédito).
} 
que não está imune aos fetiches e alienações do mundo da mercadoria.

Nas limitações apresentadas pelo econômico, a potência do desejo é mobilizadora e o aglutinador de esforços. Muitas vezes, a única explicação que os moradores têm é que assim o desejaram. Enfrentam matacões, declividades, corredeiras de água, e o formal edilício.

Não está num terceiro a explicação pelos atos. Não é nem necessidade, nem desejo que afronta. A fruição é provocativa. A fruição afronta, inclusive, as limitações naturais do terreno, ou a chamada aptidão física para a ocupação.

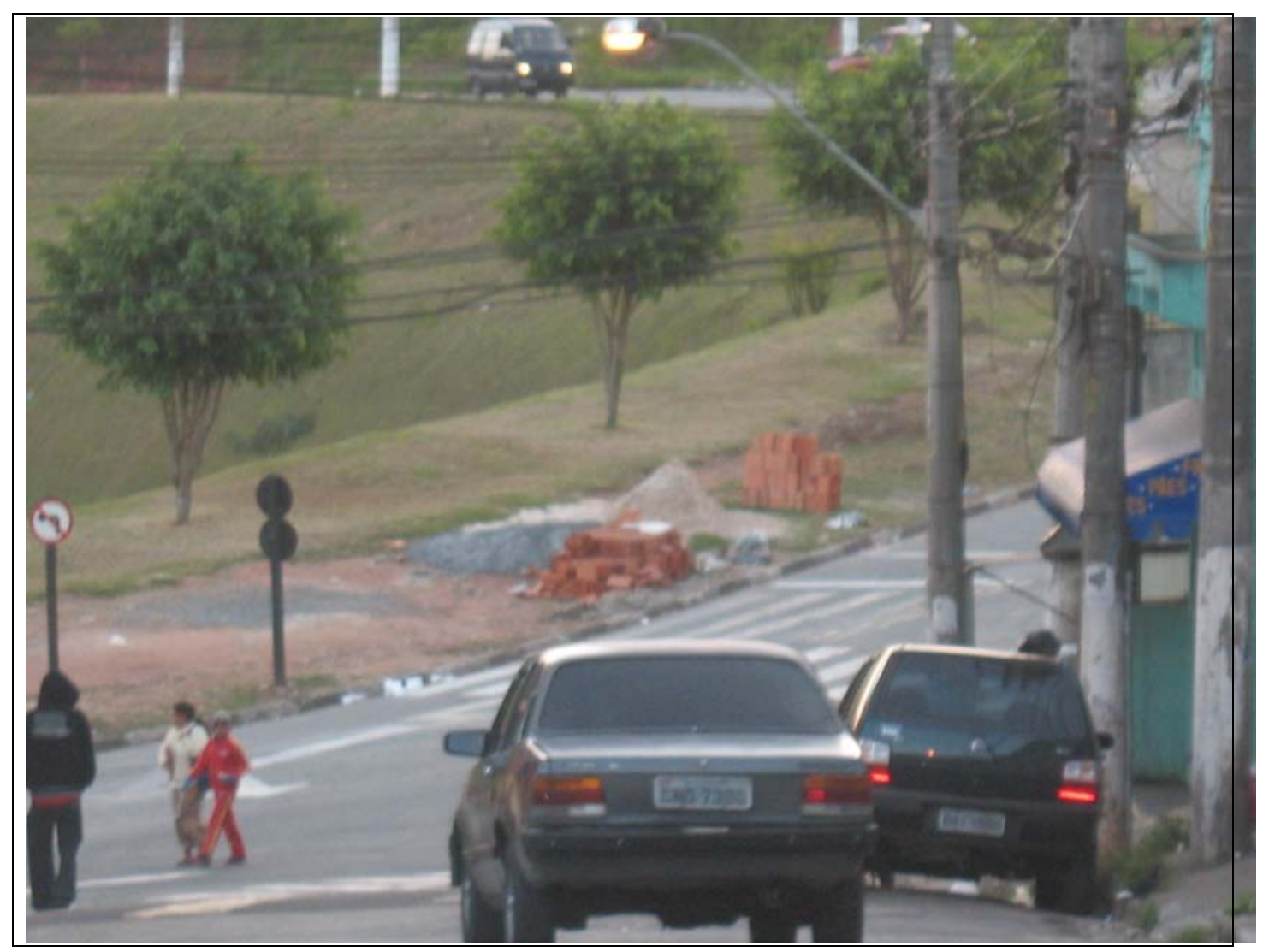


Além de ser uma patente falta de fiscalização da prefeitura, percebe-se que os próprios moradores degradam a praça. Uma das características dos ambientes de autoconstrução é o inacabado. "O que não está construindo, está demolindo." Este comentário irônico, sobre a paisagem dos ambientes de autoconstrução é recorrente. $O$ estoque de material ou o despejo dos dejetos de demolição está no passeio público. Quando não se tem um terreno vazio (espaço público, principalmente), deposita-se na própria calçada.

Não podemos associar os atos de descuido com o espaço público somente como abuso. E interpretá-los como desobediência civil ou coisa parecida seria ingenuidade. Temos aí, a alienação com um potencial explicativo e fruição no sentido de usufruto abusivo. 


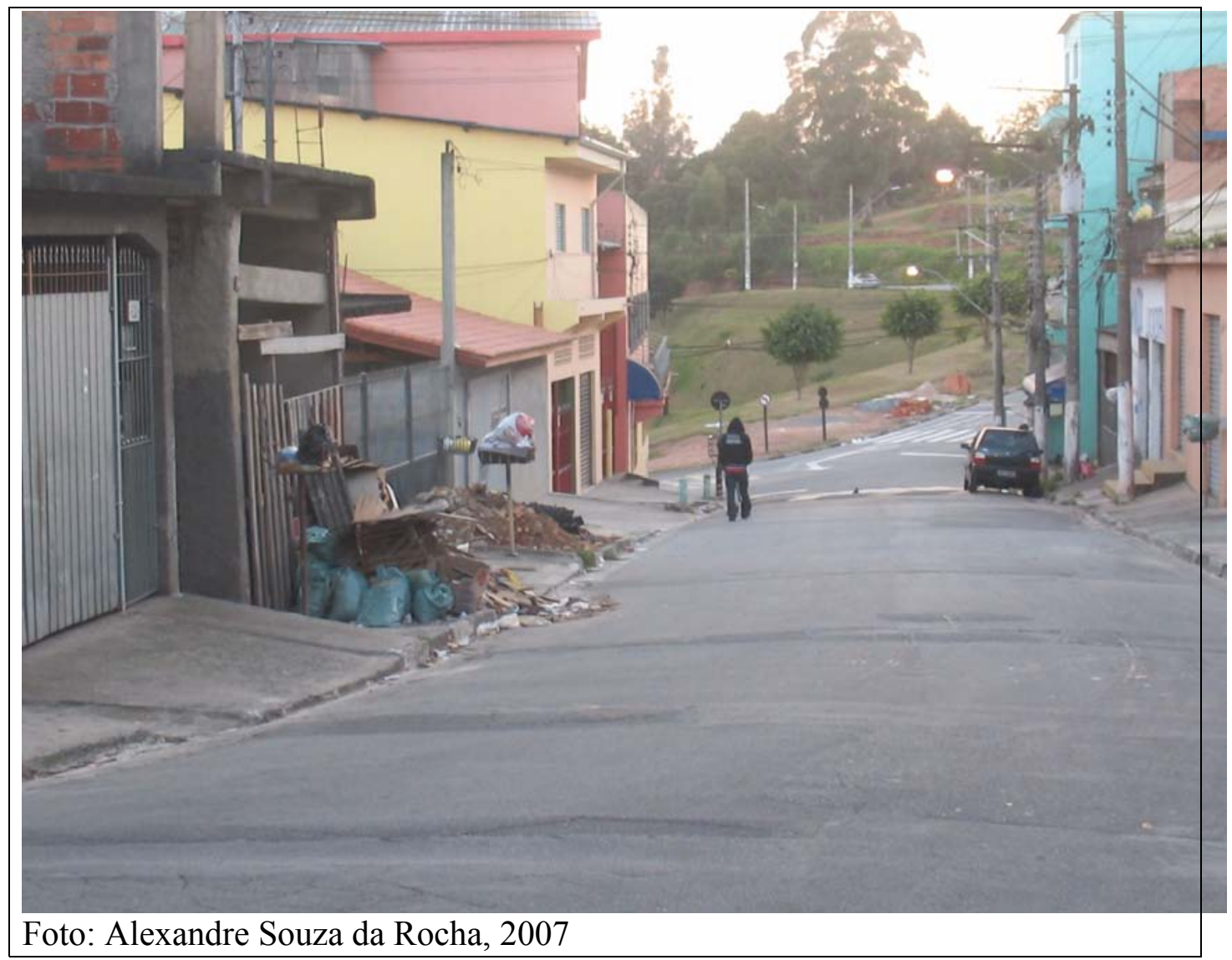

Esta foto, que apresenta um panorama mais geral da situação anterior é muito significativa, pois temos os dejetos de construções depositados à frente de cada residência, dado que nas proximidades não há terreno vazio, e lá no fundo, na praça, a deposição de material de construção, na calçada oposta, distante mas não muito da residência. Observemos que pelo aspecto das construções não se trata de local de grande miséria. Pelo contrário, os edifícios são bem acabados e apresentam alguns materiais de maior valor como portas ou portões de aço. Também podemos perceber a ausência de recuos frontais, e muitas construções juntas, que não deixaram nenhum recuo entre elas. 
Já os fundos e as laterais das construções raramente possuem algum acabamento. Não estão, como paisagem, dentro do terreno, pois fazem parte no campo visual do terreno vizinho, atrás ou ao lado, visto que nenhum recuo foi deixado.

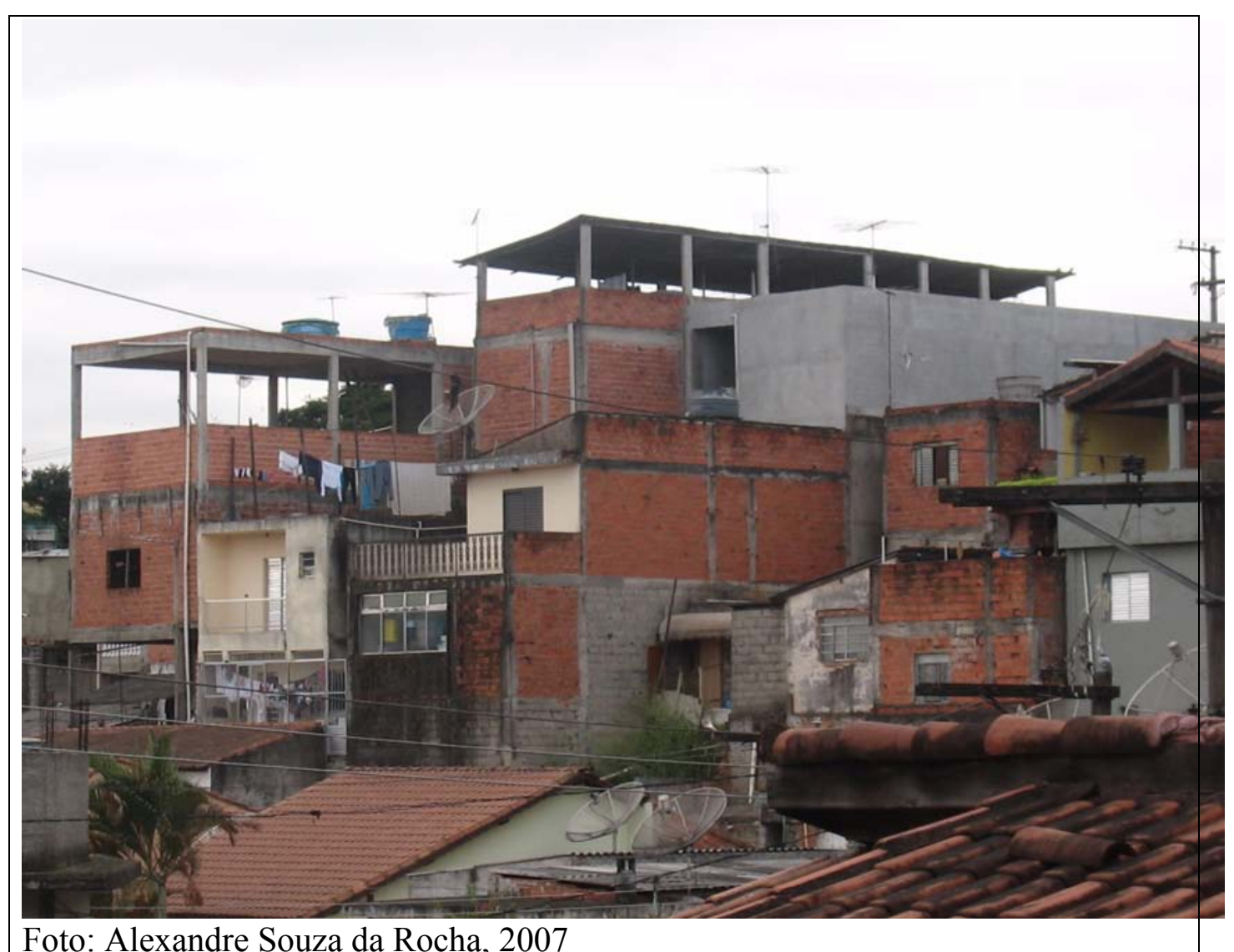

Muitos edifícios são de vários pavimentos, às vezes com várias famílias, parentes ou não. Podendo inclusive ser fonte de renda, através de aluguéis. Eis aqui outra solução habitacional dada pelos próprios trabalhadores residentes nos ambientes de autoconstrução, dada a elevação do preço da terra nos grandes centros urbanos. A reprodução da família 
fica restrita ao único terreno que foram capazes de comprar e, a cada filho (ou filha) que casa, mais um andar surge. Ou produz-se várias casas no mesmo terreno - sobrepostas ou não - para aluguel, sendo previsto um futuro para as novas configurações conjugais, adiantando-se na preocupação de garantir uma parte dos meios de vida das futuras gerações.

Mais uma vez é na subsunção formal ${ }^{42}$ do trabalho ao capital que a família do trabalhador se reproduz. Não só a produção da própria moradia foi solucionada na autoconstrução, mas é nela e no mesmo terreno que a família do trabalhador se reproduz. É um processo de reprodução do capital não contabilizado como tal, mas não é somente reprodução, está inserido no processo "inteiro", produção e reprodução das relações sociais de produção ${ }^{43}$, não aparecendo como tal, ao nível da aparência está no nível do atendimento das necessidades, ao passo que os insumos consumidos na construção e na continuidade da vida estão ao nível da circulação da mercadoria e principalmente do dinheiro. Ao arcar com a própria construção, de produtor, o mesmo trabalhador passa a consumidor, muitas vezes com

\footnotetext{
${ }^{42}$ Tendo como dado que a autoconstrução do ponto de vista do suprir os meios de vida do trabalhador, através da venda de sua força de trabalho, é extração de mais-valia absoluta.

${ }^{43}$ LEFEBVRE, H. A Re-produção das Relações de Produção. Publicações Escorpião. Porto, 1973. (já citadO)
} 
preços exorbitantes e taxas abusivas de juros nos depósitos e lojas de materiais de construção, instalados junto aos lugares de maior aceleração do espraiamento metropolitano. E se considerarmos o custo de enfrentar as limitações impostas pela aptidão física do terreno, o investimento em contenção e minimização das restrições naturais à construção, fica mais oneroso para o trabalhador. A própria construção segura o barranco, porém é exigido um investimento maior frente aos terrenos planos.

Tanto ao nível das horas necessárias à sua reprodução como trabalhador, quanto no comprometimento da renda familiar, a mais-valia é ampliada dados os limites da reprodução do trabalhador. Considerando as dificuldades acrescentadas pelas restrições físicas dadas pelas "aptidões para a ocupação" temos a ampliação da mais-valia absoluta com a ampliação do tempo de trabalho, empreendendo esforços físicos, bem como da mais-valia absoluta, dado o comprometimento da renda pelo custo maior em insumos para a obra, visto que o trabalhador necessitará receber mais (talvez com horas extras) ou retirar de outros meios de vida.

Nos ambientes de autoconstrução já consolidados, têmse uma continuidade de ampliação dos edifícios por conta da 
menor oferta de terrenos ainda não ocupados e pelo aumento que o preço da terra adquire com os investimentos em infraestrutura já executados.

Dentro da lógica do mercado formal da construção, o processo de valorização do solo urbano por conta dos investimentos diretos ou indiretos consolidados no espaço da cidade, é contabilizado desde o início do projeto. E nas nossas periferias a lógica é a mesma. O mercado imobiliário apropriase dos processos de valorização, independente da formalidade. Oriundo de empresas ou do trabalhador, o trabalho empregado na construção das residências agrega valor ao espaço e este, como mercadoria, passa a acompanhar os circuitos formais da especulação imobiliária.

Independentes da origem do investimento, da formalidade ou do respeito aos recuos, os edifícios dos ambientes de autoconstrução tornam-se capital fixo no processo de valorização do espaço. A dimensão do local de moradia como circuito formal da economia está mais patente nos empreendimentos imobiliários, nas incorporações prevendo "revitalização de espaços" Mas nos arrabaldes dos grandes investimentos, está se produzindo, com subterfúgio de inferioridade ou de informalidade, o capital especulativo 
imobiliário tanto quanto os que conjunturalmente são enquadrados como formais.

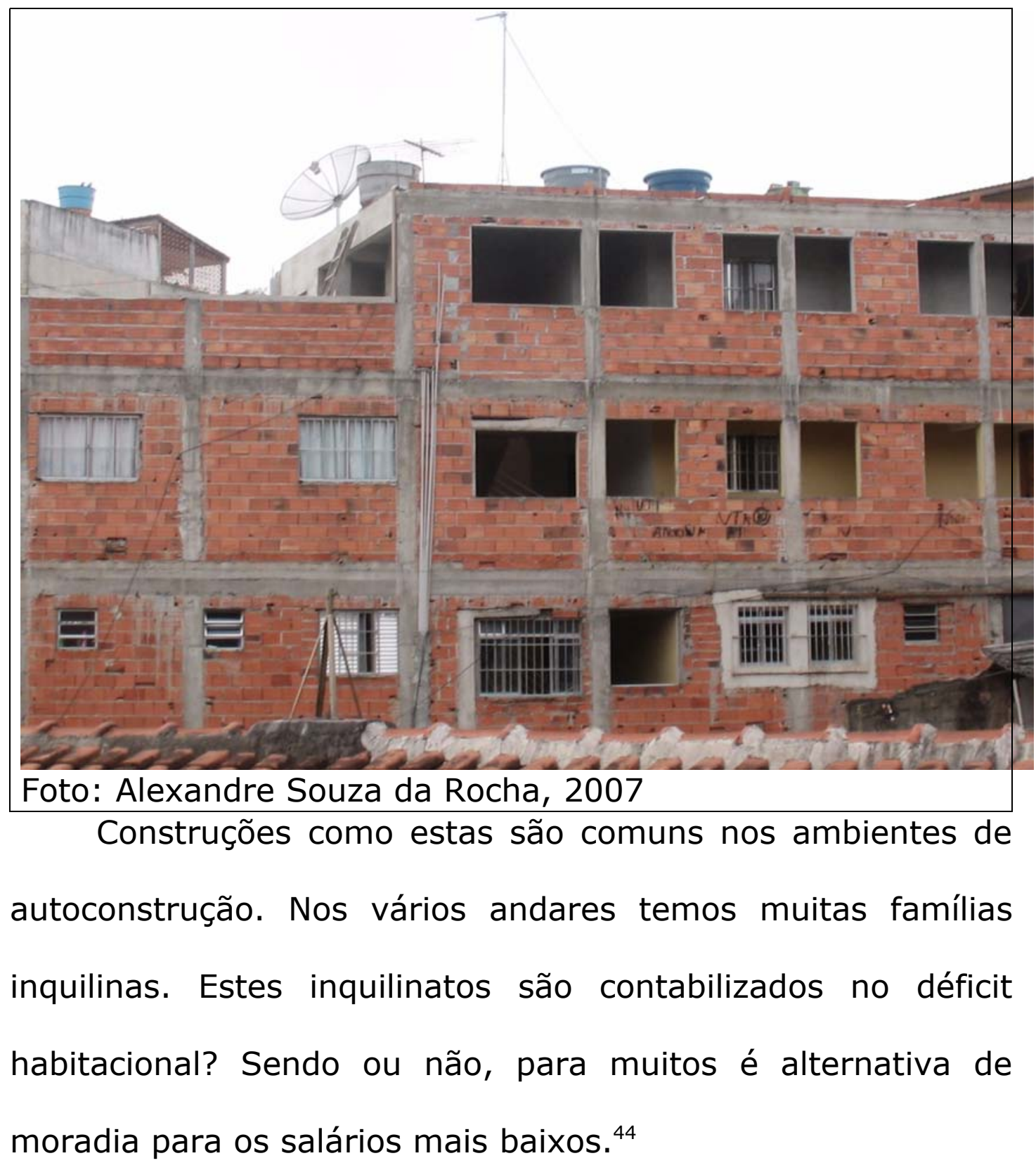

${ }^{44}$ Há que se acrescentar que os cortiços não são objeto de preocupação deste trabalho. 


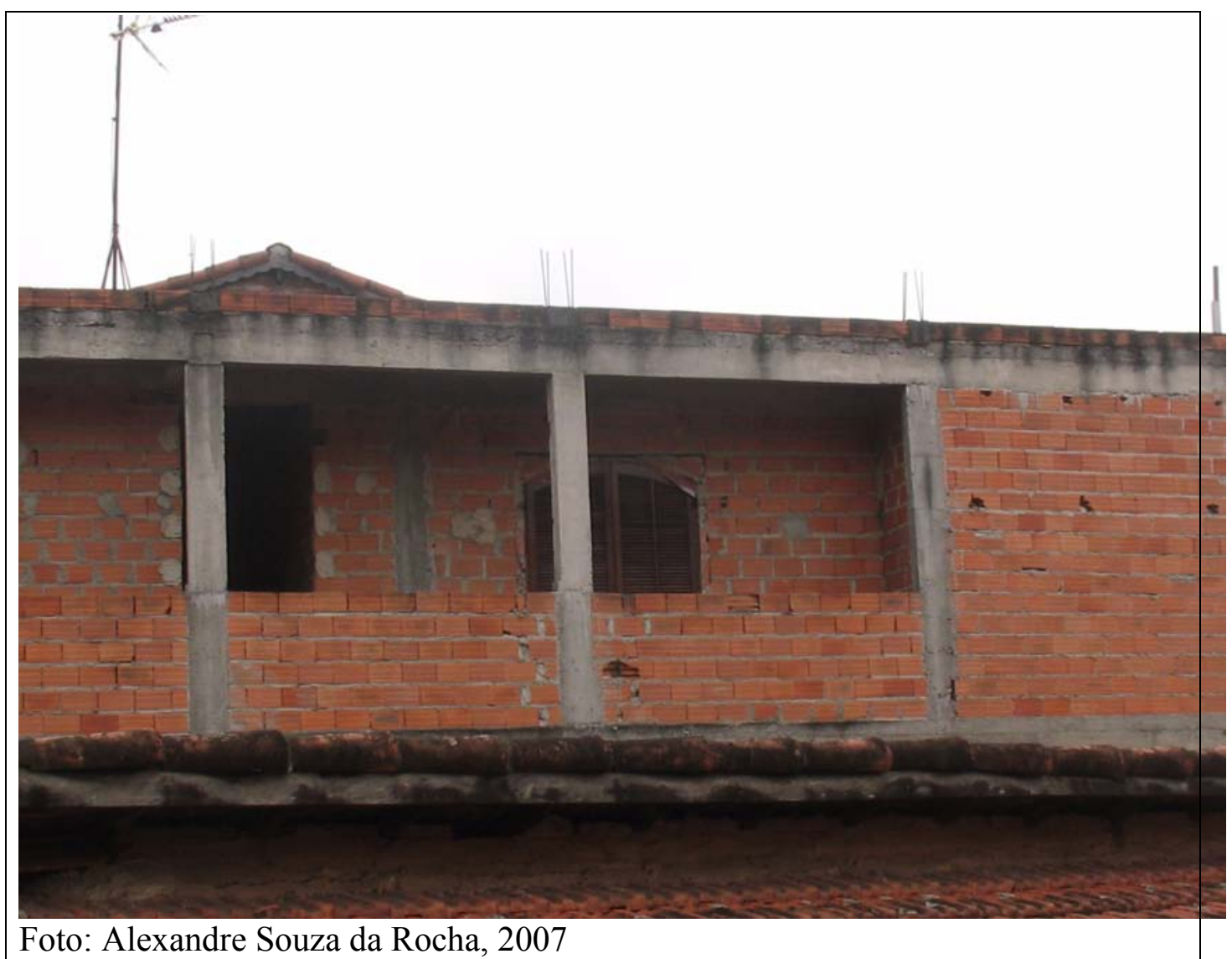

Os arranques das ferragens em cima da laje apontam um projeto futuro de construção. As residências estão habitadas e apontam como previsão de ampliação, e não serão processos corrosivos do aço, exposto às intempéries, que limitarão este devir. Aqui o econômico ou outras prioridades postergam a continuidade das obras.

Estes arranques expostos também são uma marca dos ambientes de autoconstrução. Como elemento da paisagem, este prolongamento das armações das colunas, além de recorrentes são esclarecedores. Não é a falta de acabamento 
nas construções que está no devir e sim o inacabamento, que aponta como projeção de ampliação futura.

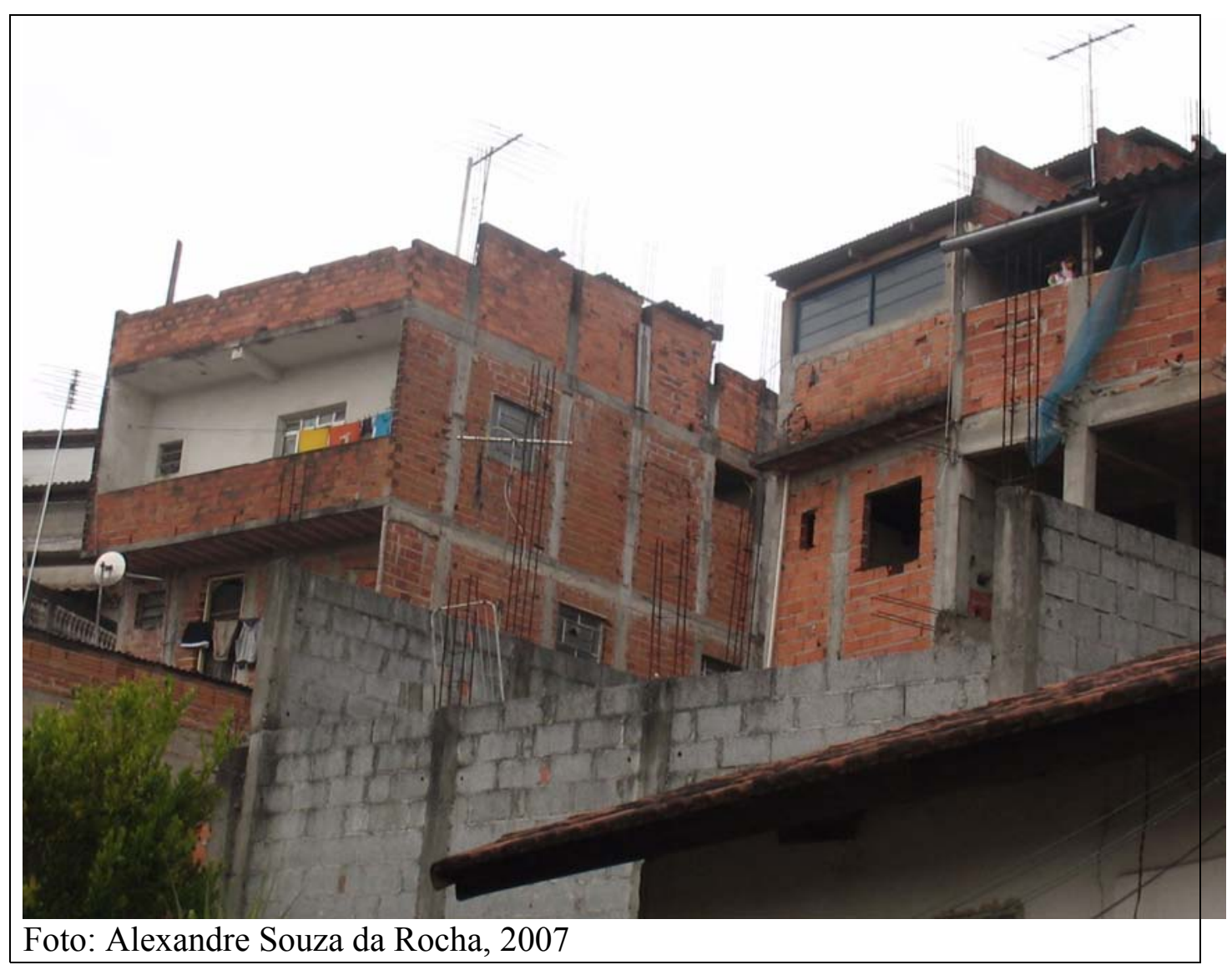

O aspecto de ruína é também uma marca do porvir. Ao contrário das ruínas pela deterioração do tempo, aqui o limite está ao nível do econômico, ou da emergência. Fica-se no aguardo de situação mais favorável para a continuidade das construções. A ferragem das colunas ou parte das paredes já adiantam a arquitetura vindoura.

Não existe dissimulação, é explícito. Esta paisagem, talvez, afronte os planejadores e os pretensos organizadores 
do espaço. Além de retratar as mazelas de nossa sociedade, também aponta abusos, ou melhor, fruições que seriam privilégio de uma burguesia ostentatória, aparece como deterioração.

Enquanto lugar, a intimidade e a intensidade do vivido impera, não somente enquanto imediaticidade, mas também como fruição. Não é uma questão estética, moral ou ética. A vida é mais que estas possibilidades de interpretação das práticas existentes. É pujante, além do espetáculo. Ao mesmo tempo, prenhe de alienações, também explicita as contradições na crítica ao modo de produção. Dá fôlego ao desemprego, não só como abrigo dos desempregados, mas no âmbito dos bicos. Abrangendo desde o servente até 0 profissional especializado, pois é o lugar destinado a moradia da classe trabalhadora, além dos conjuntos habitacionais e dos cortiços; os ambientes de autoconstrução, também, são privilegiados por serem primordiais para a reprodução do trabalhador, além do mundo do trabalho, e, ao mesmo tempo, imerso nele.

Ainda não é possível referir-se a um devir ou um sentido histórico através da tríade necessidade, desejo e fruição. A subsunção real e formal do trabalho ao capital é 
preponderante na "colocação" das pessoas na cidade, somo hierarquizados, também, pela condição de acesso à moradia, e o morar, ao mesmo tempo que sujeitado às condições sociais, políticas e econômicas, também é provocativo às determinações possibilitando inclusive a fruição. Quem sabe um devir dos ambientes de autoconstrução possa ter na obra a construção de momentos? Como localizou o Kauê no trabalho de campo sobre a implicação ${ }^{45}$. 


\section{O ambiente escolar como processo e projeto de aprendizagem}

Um grande desafio dos professores da rede pública, principalmente no ensino médio, é fazer com que a proposta pedagógica faça sentido para os alunos. É comum as nossas salas de aulas lotadas de alunos desmotivados. A lotação é um dos motivos da desmotivação. Porém, podemos falar de um conjunto de objetos, atos e situações que produzem este ambiente escolar pouco propício ao processo de ensino e aprendizagem.

Embora há muito se propague, nas esferas oficiais do ensino público, inúmeros discursos, diretrizes e planos que dizem visar mudanças no ensino de maneira a torná-lo mais interessante e próximo da realidade dos alunos, muito pouco dos elementos do movimento do real tem chegado às escolas públicas estaduais (embora no ensino privado não seja muito diferente).

Para muitos (pais, alunos, professores, direção, supervisores...) a escola aparece como um depositário de crianças, que dependendo de alguma iniciativa "genial" pode, às vezes, ajudar os jovens a adquirirem algum conhecimento. Existe um discurso que se propõe crítico a esta situação, 
porém a maioria daqueles que assimila este discurso, não consegue senão reproduzir a situação.

É raro um edifício escolar ter sua arquitetura propícia ao encontro, uma imagem muito comum de escola é um corredor com muitas portas. Visão comum também para hospitais, hotéis e, se pensarmos nas grades, presídios.

Dentro das salas temos cadeiras e carteiras pequenas para a estatura dos jovens do ensino médio; é um desconforto sem tamanho permanecer, por horas, sentados nessas cadeiras. Um desconforto rotineiro durante, obrigatoriamente, ao menos 200 dias por ano.

Em muitos casos as salas foram projetadas para 35 crianças no máximo (inclusive com um cálculo de 1 criança por metro quadrado) que é a base legal para o ensino fundamental, porém é a mesma sala que comporta no mínimo 35 jovens do ensino médio. Pois é. O número mínimo de alunos por classe no ensino médio é de 35 alunos e raramente este mínimo é desrespeitado.

Ao nível dos objetos já é revelador a falta de projeto para a juventude. Enquanto situação existe um "no meu tempo" que, além de um saudosismo sem sentido, apresenta as situações de comportamento dos alunos atuais como 
redutoras de potencialidades do passado. E este "no meu tempo" é recorrente, independente do tempo em que se está na situação de responsabilidade pelo ensino, professores jovens ou mais experientes utilizam o termo constantemente.

Embora cada experiência vivida seja única, nos relatos percebemos pouca diferença entre as situações apresentadas e as atuais, aparentemente, hoje, os jovens são menos resignados que antes. O que em situação de ensino é extremamente saudável.

Uma premissa que considero relevante em qualquer situação de ensino e aprendizagem é que "ninguém ensina nada a ninguém; a quem aprende, pois as pessoas que ensinam, ao mesmo tempo, aprendem". Se tivermos esta premissa, temos com que analisar as situações de ensino e aprendizagem, a partir do que realmente importa no ambiente escolar: que os jovens aprendam.

Muitas vezes nos ambientes escolares esquecemos 0 motivo pelo qual estamos ali, a aprendizagem, não é o "bom comportamento" que deve ser a ordem-do-dia. É obvio que a falta de comportamentos adequados atrapalha o aprendizado, mas não são estratégias de controle sobre os alunos que irão ajudá-los a aprender. A título de ilustração apresento a 
situação de um "cartão" para que os alunos pudessem sair da sala. Só seria permitido aos alunos saírem da sala se estes estivessem com um cartão que the seria entregue pelo professor. Num primeiro momento, isto aparece como um controle sobre a circulação dos alunos fora da sala de aula, mas a eficiência do cartão está em controlar os professores, para que nenhum seja mais permissivo que outros, pois com a exigência do cartão somente um aluno por sala circularia pelos corredores, um professor mais permissivo não poderia deixar que mais de um aluno saísse da sala. Em termos de ensino e aprendizagem, a existência ou não da regra do cartão não muda em nada, mas enquanto controle é eficiente sobre os professores e em relação à circulação de alunos durante as aulas, o que os inspetores teriam seria no máximo uma quantidade de alunos igual a quantidade salas de aulas, ou melhor, se no período tivermos 12 salas em aula, no máximo, ter-se-á 12 alunos circulando. E dentro da sala de aula?

Aparentemente o controle é sobre os alunos, mas na realidade o professor e o espaço escolar são, de fato, controlados. Em que esta regra contribui para aprendizagem? Dependendo do momento da aula, não é interessante que 
qualquer aluno saia, em outros momentos, não há problemas que duas meninas saiam juntas para ir ao banheiro. Para um ambiente agradável de aprendizagem é até interessante, considerando somente a questão da circulação de alunos durante as aulas, que mais gente circule. Pois areja a cabeça, melhorando as possibilidades de aprendizagem.

Algumas atitudes não contribuem em nada no processo de ensino e aprendizagem, mas seguem como regra. Até que ponto estas atitudes não interferem no método de ensino?

A constante discussão da necessidade de melhorar os métodos de ensino já aparece na década de 1940: "Há, certamente, uma 'explosão escolar', no sentido demográfico do termo, mas há igualmente a convicção crescente de que os métodos não estão adaptados ao mundo moderno e às mudanças que se esboçam. ${ }^{\prime \prime 6}$

Outras vezes objetos, atos e situações fora da sala de aula contribuem muito mais para o processo de ensino e aprendizagem.

Há alguns anos, na E. E Profa. Josepha Pinto Chiavelli, os professores são convocados à participar da festa junina beneficente da escola. Com a obrigatoriedade de

\footnotetext{
${ }^{46}$ Ardoino, Jacques / Lourau, René. As pedagogias institucionais. São Carlos: RiMa. 2003. p.08
} 
cumprimento dos duzentos dias letivos, sempre tem-se dias a compensar, ou adianta-se o recesso de dezembro. Em resumo troca-se um dia de semana por um sábado. Mas esta prática não é privilégio da nossa escola, as quadrilhas e festas juninas nas escolas há tempos fazem parte do calendário escolar.

Existe a crítica desta convocação compulsória representar um sobre-trabalho, mesmo considerando a "emenda" de um feriado ou o adiantamento do recesso de dezembro; em muitos casos o professor não é consultado. Este sábado é um prolongamento da jornada semanal, pelo menos naquela semana. Alguns professores mostram-se, o tempo todo, desagradados com a situação.

Outra crítica é o fato deste tipo de atividade servir para arrecadação financeira da escola, ou melhor, para a APM Associação de Pais e Mestres - escolar. O governo do estado deixa a cargo da comunidade escolar muitos custos de seu funcionamento. Logo, a obrigação do Estado se torna sobretrabalho para o professor.

Os insumos da festa (prêmios das barracas de brincadeiras, alimentos e bebidas que serão vendidos, etc.) são em sua maioria doações. Alguns anos promovem-se 
gincanas entre salas, nas quais a turma vencedora ganha algum prêmio - normalmente passeios. Outros anos a campanha de arrecadação fica a cargo da equipe dirigente e em anos de eleição municipal aproveita-se do assédio dos candidatos para conseguir deles contribuições. Em resumo, a comunidade escolar arca com o "beneficente", e supre parte da deficiência do serviço público. Até aqui, a relação real de aprendizagem torna-se fria, uma ausência de apropriação.

Todo ano é organizada quadrilha dos alunos, e aí vem outra crítica comum: é para atrair público para a festa. Pois cria-se um motivo a mais para os parentes e amigos comparecerem à festa junina e com isso consumirem. Antes do "josepha" tornar-se "escola de período integral" tínhamos as quadrilhas organizadas por turno (manhã, tarde e noite), agora além da possibilidade dos alunos se organizarem para dançar, também têm as aulas de "projetos", dança, artes, música... envolvendo uma parte do tempo de aula com os ensaios de cada classe, preparando apresentações temáticas para a festa.

Sobre os ensaios das quadrilhas, também é corriqueiro muitos alunos e alunas inscreverem-se para "fugir" das aulas regulares, isto quando os ensaios ocorrem no período de aula. 
O principal problema deste "oportunismo" dos alunos é no dia da apresentação, muitos alunos não comparecem, pois não têm compromisso com a exibição, estas atitudes implicam em insatisfação dos que realmente queriam fazer a apresentação. O que há de postiço nessa prática aparece, então, claramente.

No Josepha implantou-se uma sistemática interessante para a organização e no destino do resultado da arrecadação da festa. Primeiramente, evita-se qualquer gasto, tudo é doação; logo, mesmo sendo de pequeno valor, o que é posto à venda sempre tem um saldo positivo. A comunidade ${ }^{47}$ é atraída pela movimentação no dia, ou por ter alguma relação com a festa. Mas uma caracterização importante dos freqüentadores das festas juninas do Josepha é a baixa renda e, portanto, o que for oferecido para compra deve ser bem atraente e de pouco valor.

Portanto nenhum produto ou brincadeira (pescaria, caixa surpresa, boca do palhaço, derruba pinos...) pode passar de um real, o ideal é que seja em centavos. Este ano está

\footnotetext{
${ }^{47}$ Novamente o termo comunidade precisa ser esclarecido: ao nível do discurso oficial a comunidade escolar é composta por alunos, pais e/ou responsáveis professores, funcionários, direção. A população do entorno teoricamente é contemplada pela representação dos pais e alunos. Porém em muitos casos boa parte da população do entorno não tem nenhum vínculo com a escola. Atuar junto com a comunidade deve necessariamente ter em consideração as especificidades locais. No caso do Josepha, o edifício foi construído próximo à região central do município e portanto uma idéia de entorno é ampliada em função da centralidade e, por conseguinte, da polarização de sua localização. A população residente na vizinhança pouco participa da escola, pois a maioria não possui nenhum vínculo.
} 
previsto que quem comprar fichinha para brincadeiras ganha um saquinho de pipocas.

O saldo financeiro da festa fica disponível para o que se fizer necessário, pois não está vinculado ao orçamento oficial da escola. Nos últimos anos a destinação da arrecadação tem sido decidida pelos alunos. Durante um tempo abre-se espaço para sugestão, estas são apresentadas aos alunos e por votação decidem o destino do dinheiro. Com isso conseguimos espelho e porta papel para todos os banheiros dos alunos, a instalação da rádio dos alunos do Josepha, que funciona nos intervalos das aulas, cortador de grama, cortinas e ventiladores para as salas de aula e outras aquisições.

Mesmo concorrendo com a grande festa junina, com os "arraiás", com o agravante de estar localizada junto à Praça de Eventos onde se realizam as festas juninas oficiais, conseguimos no Josepha realizar as festas juninas ou (julinas).

Uma situação reveladora da baixa renda dos freqüentadores da festa do Josepha é quando realiza-se o "mercadinho". Muitas vezes doam insumos que não são consumidos em festas juninas: muitos quilos de arroz, de café, de açúcar, de macarrão, pares de sapato, de chinelos... 
enfim, uma variedade de artigos úteis para as famílias mas de pouca serventia para a festa. Daí saiu a idéia do "mercadinho". E é marcante no Josepha a voracidade do consumo no mercadinho, pois como são doações, seus preços são muito menores que os praticados no comércio comum. Normalmente o mercadinho é atividade da festa junina que dura menos tempo, pois esgotam-se os produtos muito rapidamente. Aproveitam a oportunidade para economizar no abastecimento da casa. O dinheiro que seria gasto em brincadeiras de uma festa fica direcionado ao trivial do dia-adia, que se não suprido compromete-se até a sobrevivência; mais uma vez as necessidades elementares ganham primazia.

Mesmo com todas as críticas nos meses de junho de cada ano a escola torna-se coletiva. Existe uma dificuldade enorme em mobilizar direção, professores, funcionários, pais, alunos e vizinhos em função de projetos coletivos. O corriqueiro é o individualismo nas iniciativas, mesmo nas triviais, raramente é dado aos alunos a oportunidade de se organizar ou de organizar qualquer atividade, cada professor fica absorto com o cumprimento do seu programa, e projetos; aqueles que não sejam os seus aparecem como estorvo ou intromissão. 
Como a festa junina tem este caráter de tradição, é menos rejeitada. Mas nem por isso é poupada das reclamações, principalmente pelo caráter compulsório da participação dos professores. Porém considerando as experiências, se não for por obrigatoriedade, a maioria dos professores não comparecem, pois mesmo que seja tradicional, não existe o real envolvimento de todos que participam.

Falta uma sensibilização para o projeto. Raramente é trabalhado algum conteúdo em sala de aula das disciplinas do núcleo comum. Não há um real envolvimento da comunidade. Com isso o que poderia ser um momento da escola torna-se comprometimento sem compromisso.

O projeto fica a cargo da direção e coordenação da escola, os outros são participantes ou colaboradores, não fazem o projeto, estão nele. Se desde o início tivéssemos uma maior inserção na organização, ter-se-ia mais envolvidos e poderíamos aferir resultados positivos além do financeiro. Os alunos que se envolvem com a escola melhoram seu desempenho escolar. Os professores poderiam ver além do corriqueiro do seu trabalho. Um dos privilégios de nossa profissão é a possibilidade de criar, de sair da mesmice, e a 
festa em sua origem é o rompimento do corriqueiro, é o espaço do efêmero. Perdemos muito isolados nas nossas salas, remoendo emoções fundadas num dia-a-dia insuficiente para nossas ansiedades, com o agravante de a principal delas ser que nossos alunos, no geral, não gostam de estudar. A frustração em relação ao desempenho profissional é ampliada pelas situações compulsórias, como a obrigatoriedade de trabalhar num sábado.

Fica o receio de aparecer como "peleguismo" ou falta de compromisso com as especificidades e a importância do conhecimento específico de cada disciplina a defesa da construção de momentos e situações no ambiente escolar que passem por mudanças de horário interferindo na rotina escolar.

"Os comportamentos e o estilo das relações dependem da qualidade e do número de trocas. É necessário instaurar novas relações e pô-las em ação pela pesquisa prática de novos papéis, novos estatutos, novas regras de vida. Contudo, a relação dual é regressiva, e são as relações coletivas, comportando instâncias de mediação, que é 
necessário desenvolver."48. (p.10 já está indicada na nota)

Qualquer maniqueísmo é redutor. Não cabe uma análise de correções ou incorreções, mesmo porque, dentro do que estamos vivendo, em termos de ensino público, no ensino básico de nosso país, e em especial em São Paulo, o Josepha tem conseguido algumas conquistas exemplares como a decisão ser dos alunos sobre o destino da arrecadação. Sem condicionantes, todos os alunos participam da decisão.

Todos os exemplos que nossos alunos têm de escola na mídia são estereótipos de crianças mal educadas, sem nenhum conteúdo interessante para sensibilização em favor do aprendizado. "Escolinha do Golias", "escolinha do professor Raimundo", "escola do Chaves" são programas de sucesso de audiência nos quais a atração está na demonstração clara de orgulho pela falta de conhecimento, num humor grotesco baseado em comportamentos esdrúxulos de idosos vestidos de crianças, satirizando professores de linguagem rebuscada com conteúdos "decorebas". E a impressão que fica de divertimento na escola é assim.

Nas tardes de segunda à sexta, há muitos anos, a emissora de maior audiência do país exibe um programa que 
mostra jovens da classe média alta carioca e seus dramas e peripécias dentro e fora da escola. Este tipo de programa não reflete nenhuma realidade, e não é o caso de pedir para a arte imitar a vida, mas é um desserviço criar estas situações como modelo para a juventude do nosso país.

Nossas salas de aula parecem ainda mais desinteressantes se comparadas com aquela apresentada num programa chamado "Malhação", que já pelo título propõe uma juventude cultuante do corpo em detrimento da mente. O jovem gordo é objeto de ironias e piadas, por exemplo. Alunos estudiosos são chamados de "nerds" (copiosa infâmia das estereotipagens norte-americanas), não possuem corpo escultural e nem namoram as modelos, que representam as jovens "saradas" da TV.

Nada em todos estes e outros programas levam à idéia que estudar é interessante. Aliás, quem estuda aparece como desinteressante. Porém, se alguma emissora apresentasse um programa com escolas com pouca infra-estrutura, salas lotadas e desconfortáveis, com parte dos alunos sem condições financeiras de acompanhar a moda, parcela dos professores descontentes ou despreparados e alunos interessados em aprender, buscando conhecimento e 
demonstrar sapiência, seria ainda mais absurdo que os ridículos programas existentes.

Entre os mitos da vida cotidiana está a banalização de momentos criativos, sua neutralização. A criação, o estudo exige um esforço coletivo e individual, sem "clamour" moderno. Quando aparece, o estudo é somente resultado, elitizado e tecnificado, e não processo de aprendizagem. Ele é coisificado, fetichizado, negado como relação social, a ser construída. Especialmente, no que se refere à escola pública. Um projeto de educação para a escola pública, desenhado nos atos e situações do cotidiano, revela seu grau de dificuldade, como possível-impossível. 


\section{BIBLIGRAFIA}

ANDRADE, M. M. e KOSMINSKY, E. V. O Estado e as Classes Sociais. in MARTINS, José de Souza. Henri Lefebvre e o Retorno à Dialética. Hucitec. São Paulo: 1996 Ansay, Pierre \& Shoonbrodt, René. Penser la Ville. Choix de textes philosophiques. AAM Editions. Paris: 1995

BAKER, Alan R. H. Évolution de la Géographie Historique en Grande-Bretagne et en Amérique du Nord. Herodote. . . BERGER, Peter e LUCKMANN, Thomas. A construção Social da Realidade. Ed. Vozes. Petrópolis: 1978.

CARLOS, A. F. A. A Re-produção do Espaço Urbano: O Caso de Cotia. Tese de Doutoramento. Departamento de Geografia - FFLCH - USP. São Paulo: 1987.

CHAYANOV, Alexander. La organización de la unidad económica camapesina. Ed. Nueva Vision. Buenos Aires: 1974

CHESNAIS, François. "Novo capitalismo intensifica velhas formas de exploração". Folha de São Paulo. 02/11/97, Caderno Especial.

DAMIANI, Amélia. L. A Cidade (Des)Ordenada - Concepção e Cotidiano no Conjunto Habitacional Itaquera I. Tese de Doutoramento. Departamento de Geografia - FFLCH USP. São Paulo. 1993.

inédito.

"Ainda a propósito do espaço". Paper 
DARNTON, Robert. O Grande Massacre de Gatos - e outros episódios da história cultural francesa. Ed. Graal. Rio de Janeiro: 1988.

HARVEY, D. A Justiça Social e a Cidade. Hucitec. São Paulo: 1980.

Do gerenciamento ao empresariamento: a transformação da administração urbana no capitalismo tardio. In Espaço \& Debates no 39. NERU. São Paulo. 1996

FRANCO, Maria Sylvia C. Ordem e Progresso. In Folha de São Paulo. 15/06/97. $5^{0}$ caderno, p.09-10.

DEBORD, Guy. A Sociedade do Espetáculo. Ed. Contraponto. Rio de Janeiro: 1997.

KURZ, Robert. O Colapso da Modernização: Da derrocada do socialismo de caserna à crise da economia mundial. Paz e Terra. São Paulo: 1993. . Gênese do absolutismo de mercado. Folha de São Paulo. 08/06/1997. 50 caderno. p. 3. - Desfecho do masoquismo histórico. Folha de São Paulo. São Paulo. 20/07/97. $5^{\circ}$ caderno. P. 03. - Escravos da Luz Sem Misericórdia. Folha de São Paulo. 12/01/97 50 caderno, p. 07. KUVASNEY, Eliane. "Separar para Reinar": desmembramentos na gênese da metrópole paulistana. Dissertação de Mestrado. Depto. de Geografia - FFLCH - USP. São Paulo: 1996.

LACOSTE, Yves. Le passé des territoires. Hérodote. N. ${ }^{0}$ 74/75 .p. 03-06 
Entretien avec Georges Duby. Hérodote. N. 0 74/75

.p. 07-13.

LEFEBVRE, Georges. O Grande Medo de1789. Ed. Campus.

Rio de Janeiro: 1988

LEFEBVRE, Henri. A Vida Cotidiana no Mundo Moderno. Editora Ática. São Paulo. 1991.

. Espacio y Política - El derecho a la ciudad,

II. Ediciones Península. Barcelona: 1976.

e Groupe de Navarrenx. Du Contrat de

Citoyenneté. Editions Périscope et Editions Syllepse.

Paris: 1990

nIETZSCHE. Breviários del Fondo de Cultura

Económica (226), México: 1993.

A Re-produção das Relações de Produção.

Publicações Escorpião. Porto: 1973.

La Revoluición Urbana. Alianza Editorial.

Madrid: 1979.

O Pensamento Marxista e a Cidade. Ulissea.

Povoa de Varzim: 1972.

LEFEBVRE, Henri. De lo Rural a lo Urbano. Ediciones

Península. Barcelona: 1975.

Lógica Formal, Lógica Dialética. Editora

Civilização Brasileira. Rio de Janeio: 1995

Hegel, Marx e Nietzsche ou O Reino das

Sombras. Editora Ulisseia. Póvoade Varzim: 1976.

Tiempos Equivocos. Editorial Kairós.

Barcelona: 1976. p. 221 - 257.

De L'Etat, Tome IV, Les Contradictions de

L'Etat Moderne la Dialectique et/de L'Etat. UGE. Paris ? 
Mas Alla del estructuralismo. Editorial La

Pleyade. Buenos Aires. p. 7-11.

La Obra. in La Presencia y la Ausencia -

Contribucion a la teoría de las representaciones. Fondo de

Cultura Económica. México DF: 1983.

O Marxismo. DIFEL/Saber Atual. São Paulo:

1963

La Notion de Totalité dans les Sciences

Sociales.

LENIN, Vladimir I. O Desenvolvimento do Capitalismo na Rússia - O Processo de formação do mercado interno para a grande indústria.. Abril Cultural, São Paulo: 1982.

MARICATO, Hermínia. Habitat II: polêmicas e controvérsias.

In Espaço \& Debates no 39. NERU. São Paulo: 1996.

MARINI, Luciano. A Luta Contra os Deuses. In Henri Lefebvre e o Retorno à Dialética. HUCITEC. São Paulo: 1996.

MARX, Karl. Salário, Preço e Lucro. Global Editora. São Paulo: 1988.

MARX, Karl. Miséria da Filosofia. Livraria exposição do livro. São Paulo.

Capítulo VI Inédito de O Capital - Resultados do

Processo de Produção Imediata. Editora Moraes. São Paulo: 1985.

MARX, Karl. El Capital. XXI - Siglo Veintiuno Editores S/A. Buenos Aires. Tomo I, Vol. 1, p. 18 - 20. - Tomo I, Vol. 3, p. 950 - 954. - Tomo III, Vol. 6, p. 40 - 41, 54 - 56, 106

- 111. Tomo III, Vol. 7, p. 562 - 569. 
MARX, Karl. Manuscritos Econômicos - Filosóficos e outros textos escolhidos. Abril Cultural. São Paulo, 1978. p. 10 13, 24-27.

Manuscritos Econômicos - Filosóficos de 1844.

Editorial Pluma. ?. ?. p. 90-91.

Elementos Fundamentales para La Crítica de la

Economía Política (Grundrisse) 1857-1858. XXI-Siglo Veintiuno Editores S/A. Buenos Aires. Tomo 1, p. 24-25, 444-451, 464-465, 476-479. Tomo 2, p. 30-35, 86-87, 118-123.

Teorías Sobre a Plusvalía. Editorial Camargo. ? . p. 288-289, 327-331. Tomo 2, p. 140-141, 184-185, 294-295, 356-357, 428-429, 436-437

"Para a Crítica da Economia Política" in Os Economistas. Abril Cultural. São Paulo, 1982.

MARTINS, José de Souza. Subúrbio - Vida Cotidiana e História no Subúrbio da Cidade de São Paulo: São Caetano, do Fim do Império ao Fim da República Velha. Hucitec. São Caetano do Sul: 1992. - Henri Lefebvre e o Retorno à Dialética. Hucitec. São Paulo: 1996 MORAIS, Regis. O que é violência urbana. Coleção Primeiros Passos no 26. Circulo do Livro. S/D.

NIETZCHE, Friedrich Wilhelm. O Nascimento da Tragédia - ou o Helenismo e Pessimismo. Companhia das Letras. São Paulo: 1992

A Genealogia da Moral. Guimarães Editores. Lisboa: 1990. 
PETRONE, Pasquale. Aldeamentos Paulistas. Ed. da Univ. de São Paulo. São Paulo: 1995

PITTE, Jean Robert. De la Géographie Historique. Herodote. . . ROCHA, Alexandre S. Periferia e centralidade na Grande São Paulo. Abordagem crítica sobre o morar na periferia da metrópole. Dissertação de Mestrado. Departamento de Geografia - FFLCH - USP. São Paulo: 2000.

RODRIGUES, Arlete. M. Movimentos Sociais. Primeira Versão n052. IFCH/UNICAMP. Campinas: 1993.

SADER, Eder. Quando Novos Personagens Entram em Cena Experiências e lutas dos trabalhadores da Grande São Paulo 1970-1980. Paz e Terra. São Paulo: 1995

SANTOS, M. Espaço e Método. Nobel. São Paulo: 1985. Metrópole Corporativa e Fragmentada - O Caso de São Paulo. Nobel. São Paulo: 1990

A Natureza do Espaço - técnica e tempo, razão e emoção. Hucitec. São Paulo: 1996.

Por uma Geografia Nova. HUCITEC. São Paulo: 1990.

SEABRA, Manoel. Vargem Grande: Organização e Transformações de um Setor do Cinturão-Verde Paulistano. Série Teses e Monografias no 4 - Instituto de Geografia da USP. São Paulo: 1971

SEABRA, Odette L. C. Os Meandros dos Rios nos Meandros do Poder. Tietê e Pinheiros: Valorização dos Rios e das Várzeas na Cidade de São Paulo. Tese de Doutoramento. Departamento de Geografia - FFLCH - USP. São Paulo: 1987. 
SHANIN, Teodor. La Classe Incómoda - Sociología política del campesinato en una sociedad en desrrollo (Rusia 19101925). Alianza Editorial. Madrid: 1983.

VASCONCELLOS, Luiz G. Falcão. A Habitat II: um ano depois. AGB Informa no 66. Associação dos Geógrafos Brasileiros

- Seção São Paulo. São Paulo: 1997.

WILKINSON, John. O Estado, a Agroindústria e a Pequena Produção. Estudos Rurais. Hucitec-CEPA/BA, São PauloSalvador: 1986. p. 45-69 